\title{
Geology and Paleontology of the Late Miocene Wilson Grove Formation at Bloomfield Quarry, Sonoma County, California
}
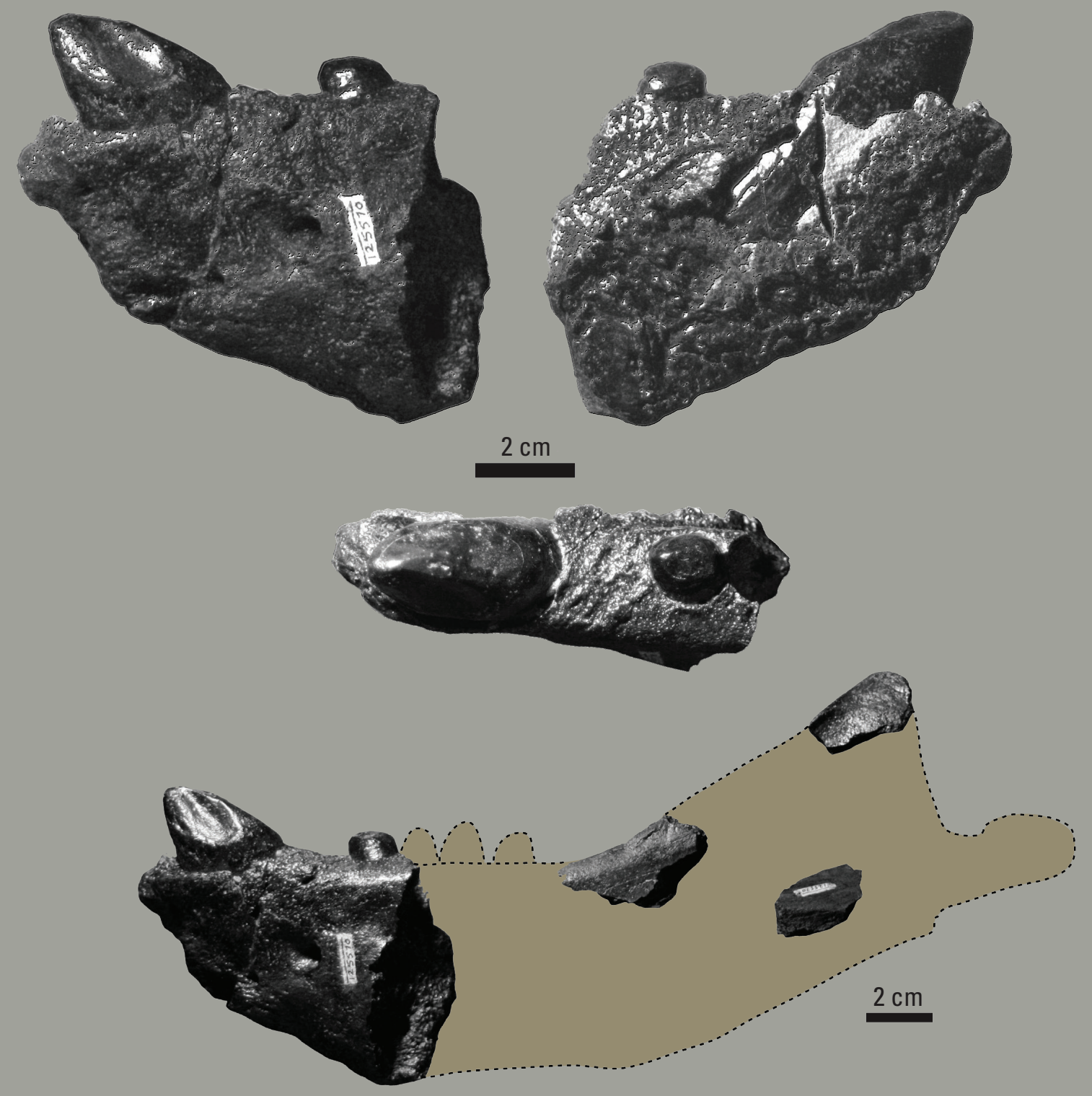

Scientific Investigations Report 2019-5021

U.S. Department of the Interior

U.S. Geological Survey 
COVER. Photographs of fragments of a walrus (Gomphotaria pugnax Barnes and Raschke, 1991) mandible from the basal Wilson Grove Formation exposed in Bloomfield Quarry, just north of the town of Bloomfield in Sonoma County, California (see plate 8 for more details). The walrus fauna at Bloomfield Quarry is the most diverse assemblage of walrus yet reported worldwide from a single locality. cm, centimeter. (Photographs by Robert Boessenecker, College of Charleston.) 


\section{Geology and Paleontology of the Late Miocene Wilson Grove Formation at Bloomfield Quarry, Sonoma County, California}

By Charles L. Powell II, Robert W. Boessenecker, N. Adam Smith, Robert J. Fleck, Sandra J. Carlson, James R. Allen, Douglas J. Long, Andrei M. Sarna-Wojcicki, and Raj B. Guruswami-Naidu

Scientific Investigations Report 2019-5021 


\title{
U.S. Department of the Interior \\ DAVID BERNHARDT, Secretary
}

\author{
U.S. Geological Survey \\ James F. Reilly II, Director
}

U.S. Geological Survey, Reston, Virginia: 2019

For more information on the USGS - the Federal source for science about the Earth, its natural and living resources, natural hazards, and the environment-visit https://www.usgs.gov/ or call 1-888-ASK-USGS (1-888-275-8747).

For an overview of USGS information products, including maps, imagery, and publications, visit https://store.usgs.gov/.

Any use of trade, firm, or product names is for descriptive purposes only and does not imply endorsement by the U.S. Government.

Although this information product, for the most part, is in the public domain, it also may contain copyrighted materials as noted in the text. Permission to reproduce copyrighted items must be secured from the copyright owner.

Suggested citation:

Powell, C.L., II, Boessenecker, R.W., Smith, N.A., Fleck, R.J., Carlson, S.J., Allen, J.R., Long, D.J., Sarna-Wojcicki, A.M., and Guruswami-Naidu, R.B., 2019, Geology and paleontology of the late Miocene Wilson Grove Formation at Bloomfield Quarry, Sonoma County, California: U.S. Geological Survey Scientific Investigations Report 2019-5021, 77 p., https://doi.org/10.3133/sir20195021.

ISSN 2328-0328 (online) 


\section{Acknowledgments}

We would like to thank Lindsey Groves (Natural History Museum of Los Angeles County) and Mary McGann (U.S. Geological Survey) for their helpful reviews. Also thanked are Christine Garcia, the late Jean DeMouthe (California Academy of Sciences), and Mark Goodwin, Patricia Holroyd, and Erica Clites (University of California Museum of Paleontology) for use of collections in their care. John K. Tucker helped find several obscure references. Janice C. Fong (University of California, Davis) and Heather B. Constable (Museum of Vertebrate Zoology, University of California, Berkeley) helped prepare tables, figures, and several of the plates. Harry Steinbeck and lessees of the Steinbeck Ranch kindly permitted sampling of the Roblar tuff on that property for age dating. 


\section{Contents}

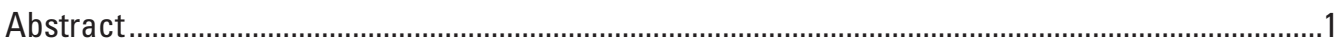

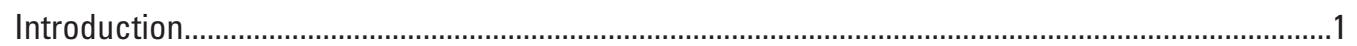

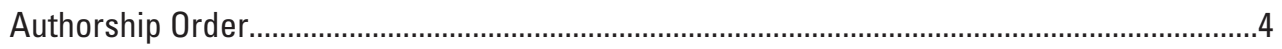

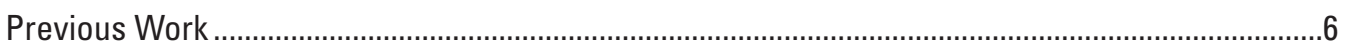

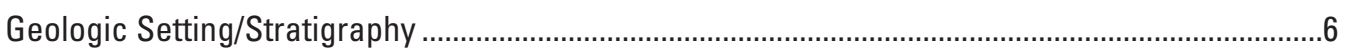

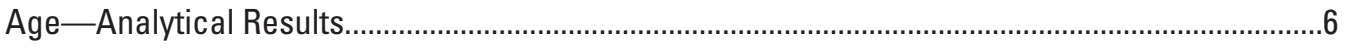

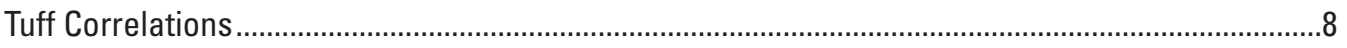

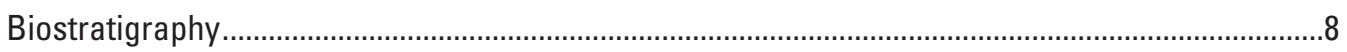

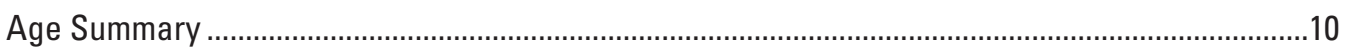

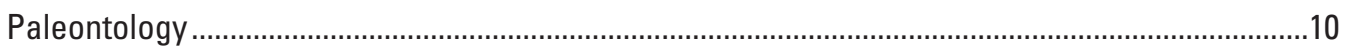

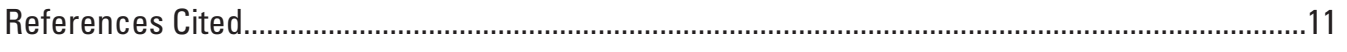

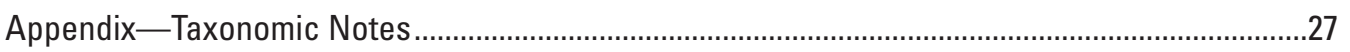

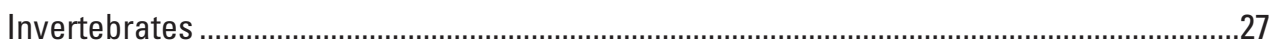

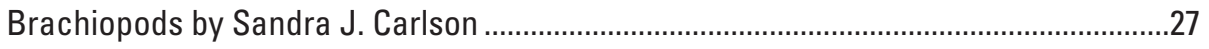

Mollusks by Charles L. Powell II .................................................................................29

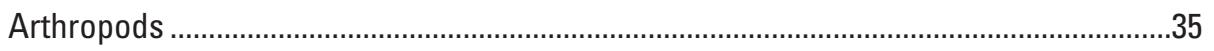

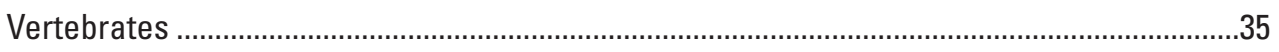

Fishes by Douglas J. Long .....................................................................................

Marine Mammals by Robert W. Boessenecker............................................................38

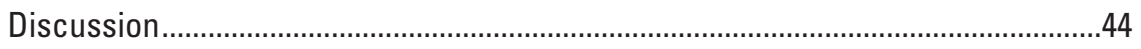

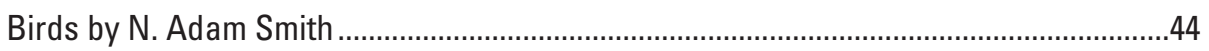

\section{Plates}

1. Selected brachiopod fossils from the basal Wilson Grove Formation exposed in Bloomfield Quarry, just north of the town of Bloomfield in Sonoma County, California.. .48

2. Selected mollusk fossils from the basal Wilson Grove Formation exposed in Bloomfield Quarry, just north of the town of Bloomfield in Sonoma County, California......................50

3. Selected mollusk fossils from the basal Wilson Grove Formation exposed in Bloomfield Quarry, just north of the town of Bloomfield in Sonoma County, California.

4. Selected fish fossils from the basal Wilson Grove Formation exposed in Bloomfield Quarry, just north of the town of Bloomfield in Sonoma County, California......................54

5. Walrus (Odobenidae) postcrania from the basal Wilson Grove Formation exposed in Bloomfield Quarry, just north of the town of Bloomfield in Sonoma County, California .56

6. Walrus (Odobenidae) teeth from the basal Wilson Grove Formation exposed in Bloomfield Quarry, just north of the town of Bloomfield in Sonoma County, California .............58

7. Walrus (Odobenidae) mandible from the basal Wilson Grove Formation exposed in Bloomfield Quarry, just north of the town of Bloomfield in Sonoma County, California .60

8. Walrus (Odobenidae) mandible from the basal Wilson Grove Formation exposed in Bloomfield Quarry, just north of the town of Bloomfield in Sonoma County, California 62

9. Walrus (Odobenidae) femur from the basal Wilson Grove Formation exposed in Bloomfield Quarry, just north of the town of Bloomfield in Sonoma County, California.. 
10. Dolphin (Odontoceti) teeth and bones from the basal Wilson Grove Formation exposed in Bloomfield Quarry, just north of the town of Bloomfield in Sonoma County, California.

11. Baleen whale (Mysticeti) bones from the basal Wilson Grove Formation exposed in Bloomfield Quarry, just north of the town of Bloomfield in Sonoma County, California.

12. Sea cow (Hydrodamalinae) rib fragments from the basal Wilson Grove Formation exposed in Bloomfield Quarry, just north of the town of Bloomfield in Sonoma County, California

13. Fragmented avian fossils from the basal Wilson Grove Formation exposed in Bloomfield Quarry, just north of the town of Bloomfield in Sonoma County, California.

14. Flightless auk (Mancallinae) fossil from the basal Wilson Grove Formation exposed in Bloomfield Quarry, just north of the town of Bloomfield in Sonoma County, California. . .74

15. Auk (cf. Uria brodkorbi Howard, 1981.) fossil from the basal Wilson Grove Formation exposed in Bloomfield Quarry, just north of the town of Bloomfield in Sonoma County, California

\section{Figures}

1. Index map $(A)$ and stratigraphic column $(B)$ showing the geology of Bloomfield Quarry, Sonoma County, California.

2. Map showing areal distribution of the informally named Roblar tuff (Sarna-Wojcicki, 1992) in northern California

3. Image showing the correlation of the Roblar tuff in northwestern and central

California

4. Cladogram depicting pan-alcid relations . .46

\section{Tables}

1. Faunal list (alphabetical) of late Miocene taxa recovered from the Wilson Grove Formation at Bloomfield Quarry, Sonoma County, California....................................................

2. Age of Miocene volcanic rocks near Bloomfield Quarry, Sonoma County, California.....7

3. Chemical and isotopic data for samples from Bloomfield Quarry, Sonoma County, California.

4. Electron-microprobe analyses of volcanic glass shards of the Roblar tephra (tuff and ash) and of an older rhyolitic pumice from a vent near the town of Roblar, Sonoma County, California, inferred to have been the source vent of the Roblar tephra (Travis, 1952) 


\section{Conversion Factors}

International System of Units to U.S. customary units

\begin{tabular}{lll}
\hline \multicolumn{1}{c}{ Multiply } & By & \multicolumn{1}{c}{ To obtain } \\
\hline \multicolumn{3}{c}{ Length } \\
\hline centimeter $(\mathrm{cm})$ & 0.3937 & inch (in.) \\
millimeter $(\mathrm{mm})$ & 0.03937 & inch (in.) \\
meter $(\mathrm{m})$ & 3.281 & foot (ft) \\
kilometer $(\mathrm{km})$ & 0.6214 & mile (mi) \\
\hline
\end{tabular}

\section{Abbreviations}

$\begin{array}{ll}\mathrm{Ar} & \text { argon } \\ { }^{40} \mathrm{Ar} /{ }^{39} \mathrm{Ar} & \text { argon-40/argon-39 } \\ \mathrm{CAS} & \text { California Academy of Sciences } \\ \mathrm{CPMS} & \text { California provincial molluscan stage } \\ \mathrm{Fe} & \text { iron } \\ \text { LACM } & \text { Los Angeles County Museum of Natural History } \\ \text { LOWESS } & \text { locally weighted scatterplot smoothing } \\ \mathrm{Ma} & \text { megaannum or millions of years } \\ \mathrm{Mn} & \text { manganese } \\ \text { NCSM } & \text { North Carolina Museum of Natural History } \\ \text { PNPMS } & \text { Pacific Northwest provincial molluscan stage } \\ \text { SDNHM } & \text { San Diego Natural History Museum } \\ \text { Sr } & \text { strontium } \\ { }^{87} \mathrm{Sr} / 86 \mathrm{Sr} & \text { strontium-87/strontium-86 } \\ \text { UCMP } & \text { University of California Museum of Paleontology } \\ \text { USGS } & \text { U.S. Geological Survey } \\ \text { USNM } & \text { National Museum of Natural History, Smithsonian Institution }\end{array}$




\title{
Geology and Paleontology of the Late Miocene Wilson Grove Formation at Bloomfield Quarry, Sonoma County, California
}

\author{
By Charles L. Powell II, ${ }^{1}$ Robert W. Boessenecker, ${ }^{2}$ N. Adam Smith, ${ }^{3}$ Robert J. Fleck, ${ }^{1}$ Sandra J. Carlson, ${ }^{4}$ \\ James R. Allen, ${ }^{5}$ Douglas J. Long, ${ }^{6,7}$ Andrei M. Sarna-Wojcicki, ${ }^{1}$ and Raj B. Guruswami-Naidu ${ }^{8}$
}

\section{Abstract}

An extensive fauna of at least 77 taxa is reported from the basal Wilson Grove Formation in a small quarry just north of the town of Bloomfield, Sonoma County, California. The fauna represents intertidal to shallow subtidal water depths and water temperatures interpreted from the fauna, consistent with the latitude of the fossil locality ( $37^{\circ}$ north) during the late Miocene. The fauna from Bloomfield Quarry is unusually large and diverse from such a small area. It consists of thousands of specimens of 4 brachiopod, 42 mollusk ( 28 bivalves and 14 gastropods), 6 arthropod ( 1 crab, 1 shrimp, and 4 barnacles), and 25 vertebrate ( 3 sharks, 1 ray, 8 bony fishes, 9 marine mammals, and 4 birds) taxa. Unusual in the fauna is the abundant and diverse brachiopod fauna, the diverse barnacle fauna, which was described previously, and the extensive and diverse vertebrate fauna. Most significant among the vertebrates is the walrus fauna, which is the most diverse assemblage of walrus yet reported worldwide from a single locality.

A single strontium $(\mathrm{Sr})$ isotope age determination of about 8 million years (megaannum, Ma) from a pectinid mollusk is consistent with a new age determination of the overlying, informally named Roblar tuff as described by SarnaWojcicki in 1992 (6.203 $\pm 0.011 \mathrm{Ma})$ and previously reported age determinations (recalculated here) from basalt $(9.27 \pm 0.06$ Ma) underlying these deposits. The Roblar tuff at Bloomfield Quarry can be correlated with other sites, including the Delgada Fan offshore northern California and the Coalinga anticline in California's Central Valley. These age determinations conform with the "Jacalitos" California provincial molluscan

\footnotetext{
${ }^{1}$ U.S. Geological Survey.

${ }^{2}$ College of Charleston.

${ }^{3}$ Campbell Geology Museum, Clemson University.

${ }^{4}$ University of California, Davis.

${ }^{5}$ ENGEO, Inc.

${ }^{6}$ California Academy of Sciences.

${ }^{7}$ St. Mary's College.

${ }^{8}$ Occidental, California.
}

stage age, the Hemphillian North American Land Mammal age determined from the fossils, and is part of the International Tortonian Stage of the Miocene.

Keywords: California, Miocene, Roblar tuff, Tortonian stage, Brachiopoda, Mollusca, Arthropoda, Vertebrata, Elasmobranch, Teleost, Mammalia, Aves.

\section{Introduction}

The Wilson Grove Formation is approximately 1,800 meters (m) thick and crops out in Sonoma County, and in a small part of Marin County, in northern California. Fossils and the informally named Roblar tuff of Sarna-Wojcicki (1992) (hereafter referred to as Roblar tuff) which occurs near the base of the formation suggest a late Neogene (late Miocene to late Pliocene) age for the formation. Several laterally varying depositional environments are represented ranging from shallower nearshore marine, which grades laterally into continental deposits of the Petaluma Formation to the east, to shelf/ slope deposits (Allen, 2003; Powell and others, 2004). The Wilson Grove Formation was deposited in a basin separate from the contemporaneous (1) Purisima Formation on the San Francisco Peninsula and in Santa Cruz County and (2) Ohlson Ranch Formation in northwestern Sonoma and southern Mendocino Counties.

This paper deals with extensive fossil collections from the basal Wilson Grove Formation made in 1973 by William F. Barbat, Raj Guruswami-Naidu, Peter U. Rodda, and Barry Roth from a small quarry north of the town of Bloomfield in Sonoma County, northern California (fig. 1). The invertebrate collections are housed at the Invertebrate Zoology and Geology section of the California Academy of Sciences, whereas vertebrates are housed with the Museum of Paleontology, University of California, Berkeley. The invertebrates were reviewed previously by Powell and others (2006), who noted the unusual fauna from the quarry and abundant brachiopods. A further study of this unusual fauna (table 1) was needed and is completed here, bringing together a wide range of experts to examine specimens in their specialties. 


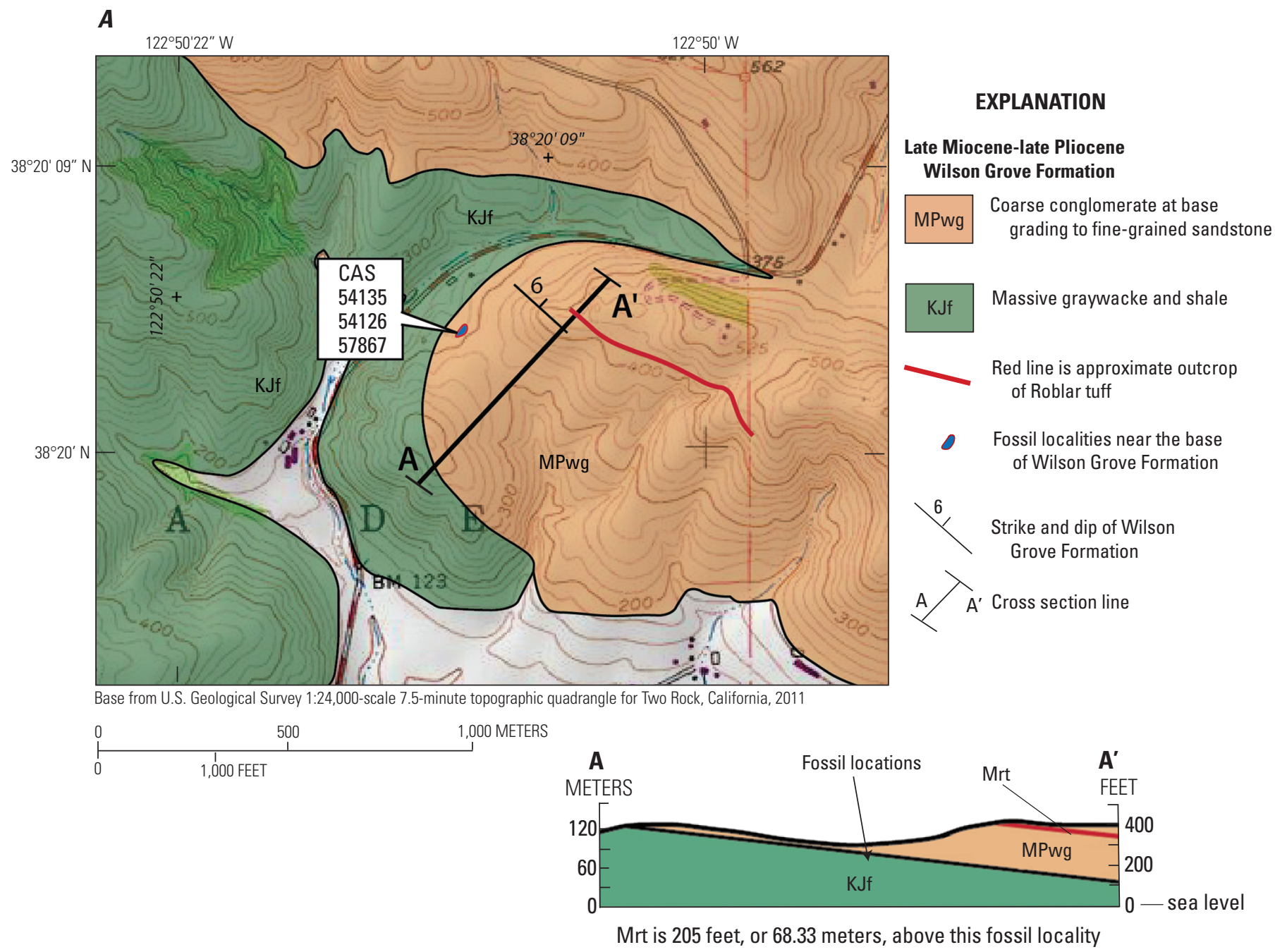

B

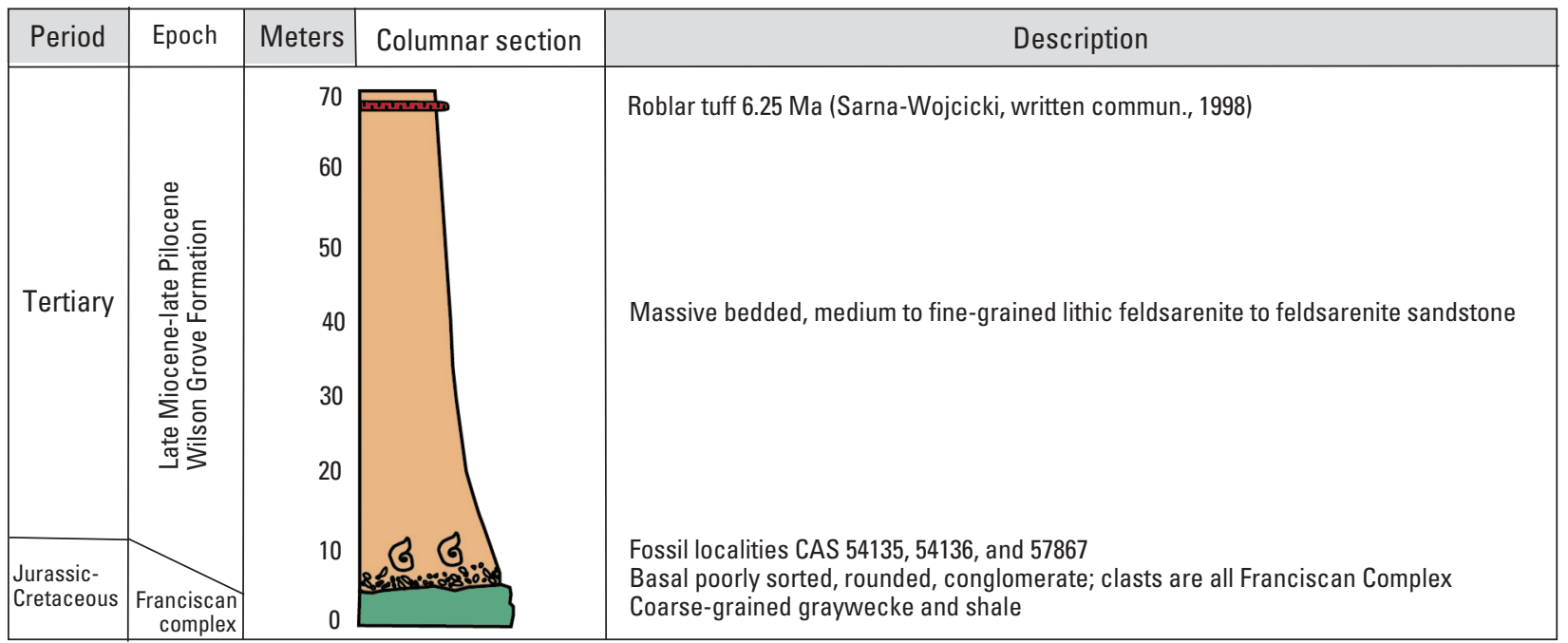

Figure 1. Index map $(A)$ and stratigraphic column $(B)$ showing the geology of Bloomfield Quarry, Sonoma County, California. California Academy of Sciences (CAS) fossil localities 54135, 54136, and 57867 are shown. Mrt, informally named Roblar tuff of Sarna-Wojcicki (1992); Ma, megaannum or millions of years ago. 
Table 1. Faunal list (alphabetical) of late Miocene taxa recovered from the Wilson Grove Formation at Bloomfield Quarry, Sonoma County, California.

[Taxa include 4 brachiopods, 42 mollusk ( 28 bivalves and 14 gastropods), 6 arthropods ( 1 crab, 1 shrimp, and 4 barnacles), and 25 vertebrates ( 3 sharks, 1 ray, 8 bony fishes, 9 marine mammals, and 4 birds)]

Brachiopoda (lamp shells)

Linguliformea

Discinisca cf. D. cumingii (Broderip, 1833)

Rhynchonelliformea

Terebratalia cf. T. transversa (Sowerby, 1846)

Terebratalia cf. T. occidentalis obsoleta Dall, 1891

Terebratulina unguicula Carpenter, 1864

Mollusca

Bivalvia (clams)

Anadara sp. indeterminate

Anomia peruviana d'Orbigny, 1846

Arca cf. A. santamariensis Reinhart, 1937

Cardiidae indeterminate

Chlamys cf. C. hodgei (Hertlein, 1925)

Chlamys aff. C. egregius (Nomland, 1917)

Chlamys cf. C. hastata (Sowerby, 1842)

Chlamys sp. indeterminate

Clinocardium? sp. indeterminate

Crenomytilus cf. C. coalingensis (Arnold, 1909)

Cryptomya californica (Conrad, 1837)

Ensis sp. indeterminate

Lucinoma annulatum (Reeve, 1850)

Macoma aff. M. indentata Carpenter, 1864

Macoma sp. indeterminate

Mactridae indeterminate

Modiolus sp. indeterminate

Mytilidae indeterminate

Panopea abrupta (Conrad, 1849)

Patinopecten sp. indeterminate

Pododesmus cf. P. macrochisma (Deshayes, 1839)

Siliqua? sp. indeterminate

Solen sp. indeterminate

Swiftopecten parmeleei (Dall, 1898)

Tellina sp. indeterminate

Teredo sp. indeterminate

Tresus pajaroanus (Conrad, 1857)

Yoldia sp. indeterminate

Gastropoda (snails)

Caesia grammatus (Dall, 1917)

Crepidula princeps (Conrad, 1856)

Crepidula sp. indeterminate

Desmondia sp. indeterminate

Lirabuccinum? sp.

Nassariidae indeterminate

Naticidae indeterminate
Neritidae indeterminate

Neogastropoda indeterminate

Nucella n. sp., cf. N. etchegoinensis (Arnold, 1909)

Nucella? sp. indeterminate

Ocenebrina? sp. indeterminate

Trochidae, indeterminate

Trochita $\mathrm{cf}$. T. diabloensis (Clark, 1915)

Arthropoda

Maxillopoda (barnacles)

Balanus aff. B. nubilus Darwin, 1854

Balanus irradians Zullo and Guruswami-Naidu, 1982

Balanus cf. B. irradians Zullo and GuruswamiNaidu,1982

Balanus? sp. indeterminate

Malacostraca (crabs and shrimp)

Callianassa? sp. indeterminate

Cancer sp. indeterminate

Vertebrata

Chondrichthyes (sharks and rays)

Hexanchus griseus (Bonnaterre, 1788)

Irusus oxyrinchus Rafinesque, 1810

Cetorhinus maximus (Guinnerus, 1765)

Myliobatis californica Gill, 1865

Osteichthyes (bony fish)

Embiotocidae, genus and species indeterminate

Merluccius sp. indeterminate

Oncorhynchus sp. indeterminate

Paralichthys sp. indeterminate

Sarda sp. indeterminate

Sardinops sp. indeterminate

Sebastes sp. indeterminate

Stereolepis sp. indeterminate

Mammalia (mammals)

Dusignathinae indeterminate (walrus)

Dusignathus santacruzensis Kellogg, 1927 (walrus)

Gomphotaria pugnax Barnes and Raschke, 1991 (walrus)

Cf. Imagoteria sp. indeterminate Mitchell, 1968

Mysticeti indeterminate (baleen whale)

Odobeninae indeterminate (walrus)

Odontoceti indeterminate (toothed whale)

Cf. Pontolis sp. indeterminate (walrus)

Sirenia indeterminate (sea cow)

Aves (birds)

Aves indeterminate

Mancallinae indeterminate

Pan-Alcidae indeterminate

Cf. Uria brodkorbi Howard, 1981 
In addition, a redetermination of the age of the Roblar tuff at its type area refines its age. Using its chemical composition, the Roblar tuff is also correlated with a number of localities in the northern and central Coast Ranges and Central Valley of California (figs. 2 and 3), as well as within sediments of the eastern Pacific Ocean. Dating of units bounding the basal Wilson Grove Formation support age determinations from argon (Ar) and strontium ( $\mathrm{Sr}$ ) analysis, tuff correlations, and paleontologic methods.

\section{Authorship Order}

The order of the authorship was determined by when each person joined the project and does not reflect the size or value of their contribution. Charles Powell wrote the introduction, previous work, geologic setting/stratigraphy/age and molluscan parts of the manuscript. The marine mammals are reported on by Robert Boessenecker. N. Adam Smith examined and reports on the bird fauna. A new age determination for the Roblar tuff was performed by Robert Fleck along with the strontium age dating. The brachiopods were examined and reported on by Sandra J. Carlson. James Allen helped with the geology/geologic setting. Fish, including sharks, were examined and reported on by Douglas Long. Andrei SarnaWojcicki wrote on tuff correlations among the Roblar tuff and other stratigraphically close tuffs in the Western United States. Lastly, Raj Guruswami-Naidu contributed to several discussions and helped collect the material on which this study is based. Everyone contributed to the introductory parts through their specialties.

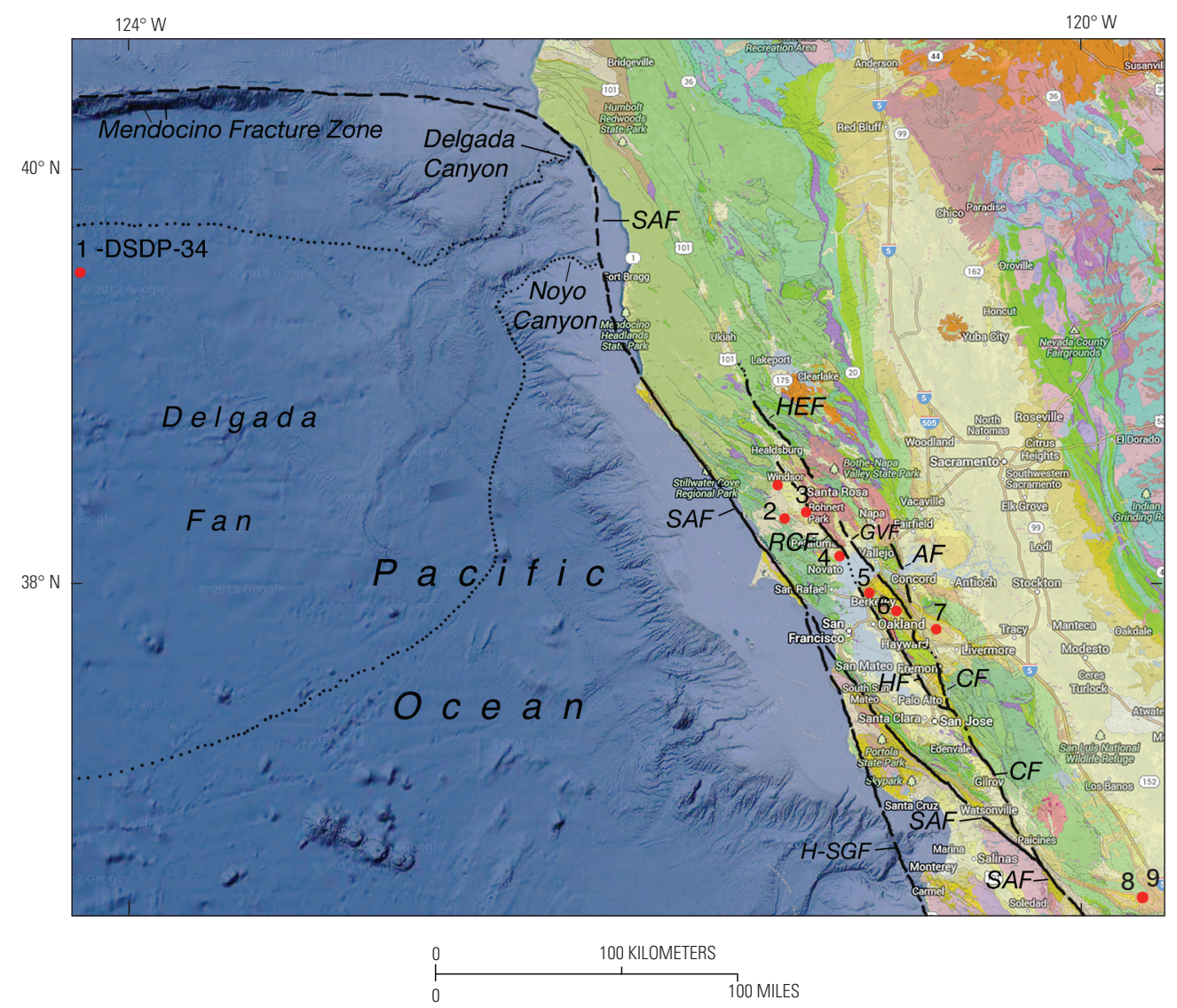

Figure 2. Map showing areal distribution of the informally named Roblar tuff (Sarna-Wojcicki, 1992) in northern California. Red dots are localities where the tuff has been identified. Numbers adjacent to the red circles refer to localities indicated in table 4 and figure 3. Solid black lines and dashed lines are major fault strands of the San Andreas Fault system. The Roblar tuff has been found in bottom sediments of the eastern Pacific Ocean (site 1, Deep-Sea Drilling Project hole 34 (DSDP-34), at extreme left), as well as within several fault-bounded blocks of the San Andreas Fault system (sites 2 through 8). The geometry of this distribution indicates progressive rightlateral displacement of the tuff and associated sediments by the San Andreas Fault system, and the displacement of the Delgada and Noyo Canyons from the Wilson Grove Formation (site 2), along the main trace of the San Andreas Fault Zone, between the Pacific and North American tectonic plates over the past 6.2 million years (Sarna-Wojcicki, 1992, and Sarna-Wojcicki, written commun., 2016). The Roblar tuff is present at the Bloomfield Quarry location at and near site 2 (see table 4), the locality discussed in the present study. SAF, main trace San Andreas Fault; H-SGF, Hosgri-San Gregorio Fault; RCF, Rodgers Creek Fault; HEF, Healdsburg Fault; MF, Maacama Fault; GVF, Green Valley Fault; AF, Antioch Fault; HF, Hayward Fault; CF, Calaveras Fault. Map is modified from a part of the Interactive Geologic Map of California (California Geological Survey, 2010). 


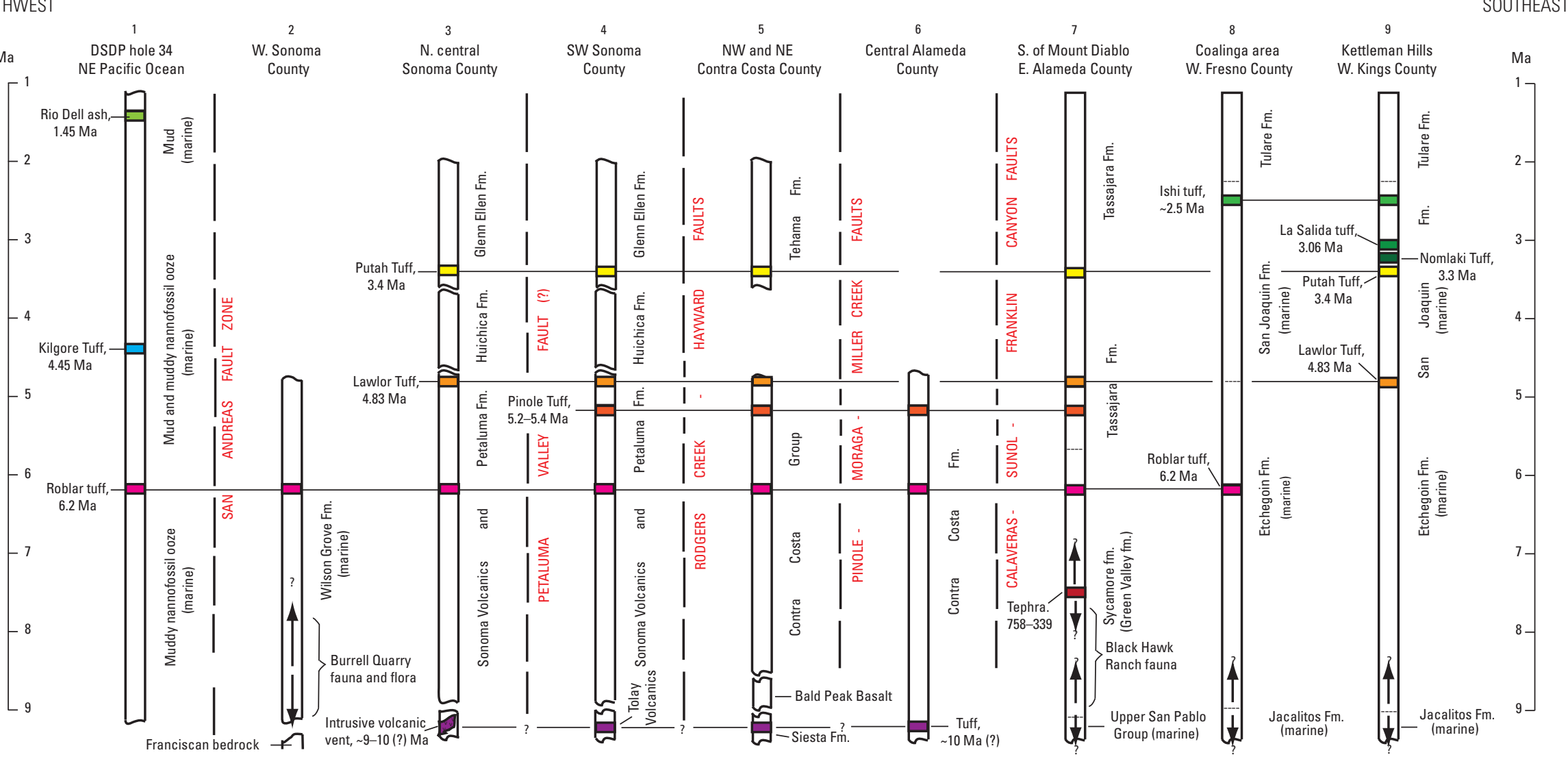

Figure 3. Image showing the correlation of the Roblar tuff in northwestern and central California and relations to other stratigraphic units. The stratigraphic relations of the Roblar tuff to other dated tephra layers are shown for a number of localities (1-9) at which the Roblar tuff has been identified. The localities are arranged geographically from the northwest to the southeast (from locality 1, at Deep-Sea Drilling Project (DSDP) hole 34 in the submarine Delgada Fan in the eastern Pacific Ocean, to locality 8, in the Coalinga area of western San Joaquin Valley, California) and according to age within each locality (age scale, in millions of years, on the far left). The Roblar tuff does not crop out in the Kettleman Hills, farther to the southeast (locality 9) but is presumed to be present in the subsurface there in the anticline of the Kettleman Hills, stratigraphically beneath the Lawlor Tuff. Names of faults of the San Andreas Fault system separating the localities from each other are shown in red. Names of the formations within the sections appear to the right of the stratigraphic column at each locality. Marine formations are designated as such; other formations are terrestrial or, as in the case of the Petaluma Formation, estuarine. See figure 2 for map locations of tuff localities 1 through 8 . Localities at which all the units within the section are exposed are shown with solid vertical lines; localities at which the section is composite, from several sublocalities within a small area, are shown with broken vertical lines, and different parts of the composite section are separated by wavy lines. Ma, megaannum or millions of years ago; fm., formation; E., east; N., north; NE, northeast; NW, northwest; S., south; SW, southwest; W., west. 


\section{Previous Work}

A full discussion of works related to the Wilson Grove Formation can be found in Powell and others (2004) with the addition of Powell and others (2006), which discusses fossil and lithologic correlations between two wells in the Santa Rosa plain and the type Wilson Grove Formation. Works specifically mentioning Bloomfield Quarry are Zullo and Guruswami-Naidu (1982) and a section in Powell and others (2004). Zullo and Guruswami-Naidu (1982) described a barnacle fauna of five taxa from the basal conglomerate at Bloomfield Quarry. They misidentified the Roblar tuff with relation to the basal fossil beds, reporting the tuff a few meters above the base of the formation, whereas Powell and others (2004) report that the tuff lies greater than $65 \mathrm{~m}$ above the base of the formation. We are uncertain if the tuff reported by Zullo and Guruswami-Naidu is the Roblar tuff or another tuff and the site is no longer accessible. Powell and others (2004) reported an invertebrate fauna of 47 taxa from Bloomfield Quarry.

\section{Geologic Setting/Stratigraphy}

The Wilson Grove Formation crops out in an inactive quarry on the east side of Bloomfield Road between Bloomfield and where the road turns sharply north-northwest at the intersection of Bloomfield Road and Canfield Road in Sonoma County (fig. 1); this quarry is referred to as the Bloomfield Quarry (Powell and others, 2004). At Bloomfield Quarry the Wilson Grove Formation overlies interbedded greywacke and shale of the Jurassic to Cretaceous Franciscan Complex mélange (Bezore and others, 2003) along an angular unconformity/nonconformity. The Wilson Grove section above the Franciscan Complex begins with a 0.3- to 0.6-m-thick basal conglomerate containing abundant sand with pebbleto cobble-size clasts of the Franciscan Complex rock and abundant disarticulated fossil shell fragments in an upward fining, gritty sandstone, which pinches out to the south. The basal conglomerate is conformably overlain by about $5 \mathrm{~m}$ of less fossiliferous, massive-bedded, friable to locally calcitecemented, fine- to medium-grained, very well-sorted, sandstone. The aforementioned outcrop at the quarry is capped by about a meter of soil.

The Roblar tuff crops out on the hill to the east stratigraphically higher in the Wilson Grove Formation, overlying a thickness of at least $68 \mathrm{~m}$ of intervening sedimentary strata (Powell and others, 2004). This thickness varies dramatically elsewhere as elevations of the base of the Wilson Grove show at least $100 \mathrm{~m}$ of relief on the opposite side of the ridge from the quarry as shown by Bezore and others (2003) and Powell and others (2004). The tuff is a well-known, well-dated volcanic unit interbedded within the Wilson Grove Formation and has been used to constrain a rather precise age datum (SarnaWojcicki, 1992; McLaughlin and others 2012). Bedding within sedimentary rocks in the quarry outcrop is the same with respect to the bedding within the tuff outcrop. Between the Bloomfield Quarry and the Roblar tuff, outcrops are spotty consisting of typical thick, bioturbated, massively bedded to occasionally hummocky cross-stratified, medium-grained, well-sorted, subangular feldsarenite sandstone beds (Holland and Allen, 1998; Allen, 2003) with a sparse fauna mostly concentrated low in the upper unit.

\section{Age-Analytical Results}

Argon-40/argon-39 $\left({ }^{40} \mathrm{Ar} /{ }^{39} \mathrm{Ar}\right)$ age determinations of volcanic units that stratigraphically overlie and underlie the Bloomfield Quarry stratigraphic horizon and a single successful Sr dating analysis from an indeterminate pectinid (Mollusca: Bivalvia) shell from the basal conglomerate support the less precise results from mollusk age ranges. At Roblar Road, less than 4 kilometers $(\mathrm{km})$ southeast of the quarry, the base of the Wilson Grove Formation rests on Miocene basalt (Bezore and others, 2003), which forms a wedge whose thickness increases locally eastward between the sediments and the underlying Franciscan Complex. The basalt is about $100-110 \mathrm{~m}$ below the Roblar tuff, and the two volcanic units provide very good age control for the Wilson Grove Formation at this location. Wagner and others (2011) report an age of $9.27 \pm 0.06 \mathrm{Ma}$ (recalculated to new constants) for outcrops of the basalt on the south side of Roblar Road (table 2, sample TW-5C-B), establishing a maximum age for the base of the Wilson Grove Formation in these exposures. Table 2 also shows similar ages for two basalts (088-27A and B) $18-20 \mathrm{~km}$ to the southeast near Petaluma, California, that occupy identical stratigraphic positions, resting on Franciscan Complex and underlying the Wilson Grove Formation (Bezore and others, 2002; Wagner and others, 2002).

A sample of the Roblar tuff (088-27D) was collected from the Steinbeck Ranch on the north side of Roblar Road, about $1.5 \mathrm{~km}$ northeast of the basalt TW-5C-B and about $2.5 \mathrm{~km}$ east of Bloomfield Quarry. The tuff sample is a pumice-clastbearing, water-lain tuff with white pumice clasts as great as 10 centimeters $(\mathrm{cm})$ in diameter in a clastic matrix of mixed volcanic and detrital components. The pumice clasts were separated from the matrix, and all matrix was removed from each clast with a small grinding tool. Pumice clasts were then brushed free of remaining loose grains, crushed, and plagioclase was separated by heavy-liquid techniques. All adhering glass was removed with dilute hydrofluoric acid. Plagioclase from this sample of Roblar tuff was analyzed by the ${ }^{40} \mathrm{Ar} /{ }^{39} \mathrm{Ar}$ incremental-heating technique. Based on a monitor age of 28.198 million years (megaannum, Ma) for Fish Canyon Tuff sanidine (Kuiper and others, 2008), an age of $6.203 \pm 0.011 \mathrm{Ma}$ was obtained combining the results of two separate, incremental-heating experiments (table 2) (monitor age refers to the age of the mineral standard or "monitor" to which the unknown 
sample is referenced in ${ }^{40} \mathrm{Ar} /{ }^{39} \mathrm{Ar}$ dating to calculate an age). This represents a redetermination of the age of the Roblar tuff at the area of its original designation (Sarna-Wojcicki, 1992) and is considered the most reliable.

The temporal variation of strontium-87/strontium- 86 $\left({ }^{87} \mathrm{Sr} /{ }^{86} \mathrm{Sr}\right)$ in seawater can be used to constrain the age of deposition of a variety of Sr-bearing materials (Peterman and others, 1970; Burke and others, 1982; Veizer, 1989; McArthur and others, 2001). Two fragments of an indeterminate pectinid (Mollusca: Bivalvia) from California Academy of Sciences (CAS) locality 54135 were analyzed for Sr chronology using the dissolution methods of Bailey and others (2000). Results of inductively coupled plasma mass-spectrometry analyses of the shell material show that one sample exhibited diagenetic patterns indicating chemical exchange in an open system, incorporating large amounts of both iron $(\mathrm{Fe})$ and manganese
(Mn) and exhibiting a lower than expected Sr concentration (table 3). $\mathrm{Mn}$ and $\mathrm{Fe}$ commonly increase during alteration and exchange, whereas Sr may decrease (Brand and Veizer, 1980). Denison and others (1994) showed that limestone samples with the lowest $\mathrm{Fe}$ and $\mathrm{Mn}$ and the highest $\mathrm{Sr} / \mathrm{Mn}$ ratios were the most likely to retain the original strontium isotope ratio of the seawater (Jones and others, 1994, McArthur and others, 2000). For quarry sample CAS 54135-1 both the $\mathrm{Sr} / \mathrm{Mn}$ and $\mathrm{Sr} / \mathrm{Fe}$ molar ratios shown in table 3 are well below those of the EN-1 modern shell standard and consistent with postdepositional alteration. Sample CAS 54135-2 also shows lower $\mathrm{Sr}$ and somewhat elevated Mn (table 3). However, its $\mathrm{Fe}$ values are less than the EN-1 values and its molar $\mathrm{Sr} / \mathrm{Fe}$ value is similar to EN-1. In view of its inconclusive compositional ratios, CAS 54135-2 must be considered suspect, but seawater $\mathrm{Sr}$ age information was calculated for

Table 2. Age of Miocene volcanic rocks near Bloomfield Quarry, Sonoma County, California.

[Ma, megaannum or millions of years ago; GM, groundmass separate; Plag, plagioclase; NAD27, North American Datum of 1927; $\sigma$, standard deviation; MSWD, mean-square weighted deviation]

\begin{tabular}{|c|c|c|c|c|c|c|c|}
\hline Sample number & Material & $\begin{array}{c}\text { Latitude } \\
\text { (North) } \\
\text { NAD27 }\end{array}$ & $\begin{array}{c}\text { Longitude } \\
\text { (West) } \\
\text { NAD27 }\end{array}$ & $\begin{array}{l}\text { Type of data } \\
\text { analysis }^{1}\end{array}$ & \multicolumn{3}{|c|}{$\begin{array}{l}\text { Indicated age } \\
\text { (Ma) }\end{array}$} \\
\hline $088-27 \mathrm{~A}$ & GM & 38.22374 & 122.61463 & Recoil model & 9.928 & 0.041 & 3.80 \\
\hline 088-27B & GM & 38.22011 & 122.64305 & Recoil model & 9.786 & 0.049 & 2.99 \\
\hline TW-5C-B & GM & 38.31509 & 122.80510 & Plateau & 9.268 & 0.058 & 1.5 \\
\hline
\end{tabular}

${ }^{1} \mathrm{~A}$ "plateau" age is the weighted mean age of contiguous, concordant age steps representing at least 50 percent of the potassium-derived. Argon-39 $\left({ }^{39} \mathrm{Ar}\right)$ released in an incremental-heating experiment (Fleck and others, 1977). A "recoil model" age is calculated as the integrated age of contiguous age steps and fractions of steps in a central fraction of the age spectrum (Fleck and others, 2014).

${ }^{2}$ All ages are calculated to a monitor age equivalent to an age of 28.198 Ma for Fish Canyon Tuff sanidine.

${ }^{3}$ Mean-square weighted deviation, a measure of goodness of fit, comparing the observed scatter to that expected from calculated analytical errors (McIntyre and others, 1966).

Table 3. Chemical and isotopic data for samples from Bloomfield Quarry, Sonoma County, California.

[CAS, California Academy of Sciences. Samples 54134-1 and 54134-2 are Chlamys (Mollusca: Bivalvia) fragments from CAS locality 54135. Sr, strontium; Ca, calcium, Mn, manganese; Fe, iron; Rb, rubidium; ${ }^{87} \mathrm{Sr} /{ }^{86} \mathrm{Sr}$, strontium-87/strontium-86; ppm, parts per million; \%, percent; $\sigma$, standard deviation; Ma, megaannum or millions of years ago; --, no data]

\begin{tabular}{|c|c|c|c|c|c|c|c|c|c|c|c|c|}
\hline $\begin{array}{c}\text { CAS } \\
\text { sample no. }\end{array}$ & $\begin{array}{c}\mathrm{Sr} \\
(\mathrm{ppm})\end{array}$ & $\begin{array}{l}\mathrm{Ca} \\
(\%)\end{array}$ & $\begin{array}{c}\text { Mn } \\
(\mathrm{ppm})\end{array}$ & $\begin{array}{c}\mathrm{Fe} \\
(\mathrm{ppm})\end{array}$ & $\begin{array}{c}\mathbf{R b} \\
\text { (ppm) }\end{array}$ & $\begin{array}{c}\text { Molar } \\
\text { Sr/Ca } \\
\times 1,000\end{array}$ & $\begin{array}{l}\text { Molar } \\
\text { Sr/Mn }\end{array}$ & $\begin{array}{l}\text { Molar } \\
\text { Sr/Fe }\end{array}$ & ${ }^{87} \mathrm{Sr} /{ }^{86} \mathrm{Sr}$ & $\pm 2 \sigma$ & $\begin{array}{l}\text { Age } \\
\text { (Ma) }\end{array}$ & $\begin{array}{c} \pm 2 \sigma \\
\text { (Ma) }\end{array}$ \\
\hline $54135-1$ & 736.5 & 37.35 & 709.0 & 6,197 & 4.05 & 0.90 & 0.65 & 0.08 & 0.708761 & 0.000019 & \multicolumn{2}{|c|}{ Too altered } \\
\hline $54135-2$ & 817.1 & 36.12 & 49.3 & 1,335 & 0.05 & 1.03 & 10.39 & 0.39 & 0.708933 & 0.000019 & 7.92 & 0.46 \\
\hline \multicolumn{13}{|l|}{ Standards } \\
\hline EN-1 & 1,201 & 4.717 & 0.45 & 1,628 & 0.044 & 1.58 & $1,672.22$ & 0.47 & 0.709173 & 0.000014 & -- & -- \\
\hline SRM987 & -- & -- & -- & -- & -- & -- & -- & -- & 0.710243 & 0.000018 & -- & -- \\
\hline
\end{tabular}


this sample (table 3 ). An age and uncertainty were assigned using the look-up table for conversion of ${ }^{87} \mathrm{Sr} r{ }^{86} \mathrm{Sr}$ in minerals, LOWESS version 3, the best-fit to the Sr seawater variation curve of McArthur and others, 2001 (also see Howarth and McArthur, 1997). The age of 7.92 $\pm 0.46 \mathrm{Ma}$ obtained from these data is consistent with age constraints provided by the ${ }^{40} \mathrm{Ar} /{ }^{39} \mathrm{Ar}$ ages of bracketing volcanic units but would benefit from $\mathrm{Sr}$ testing of less altered samples from the quarry.

\section{Tuff Correlations}

Within the Wilson Grove Formation, the Roblar tuff is continuously exposed to the east-southeast of Bloomfield Quarry for about $6.5 \mathrm{~km}$ and discontinuously exposed to the northwest for about $9.5 \mathrm{~km}$ to near Jonive School (Travis, 1952). The tuff dips at a low angle $\left(3-5^{\circ}\right)$, generally toward the northeast, and is broadly exposed in the hilltops and hillsides within a 2- to $3 \mathrm{~km}$-wide belt between these localities. The Roblar tuff is also exposed in a small area near Trenton, on the south side of Mark West Creek, where it is present on the north side of a fault that has uplifted the lower part of the Wilson Grove Formation and the Franciscan bedrock and juxtaposed it with the upper part of the Wilson Grove Formation, lying to the southwest of the fault.

Multiple chemical analyses of volcanic glass obtained from the Roblar tuff have been made using several different analytical techniques - energy-dispersive X-ray fluorescence, electron-microprobe analysis, and instrumental nuclear activation analysis (Sarna-Wojcicki, 1971, 1976; and unpublished data in the data repository of the Tephrochronology Project, U.S. Geological Survey, Menlo Park, CA 94025). These analyses make it possible to derive a unique chemical signature (a chemical "fingerprint") for this tephra layer, which allows us to distinguish this tephra layer from others, to correlate it between outcrops that are not continuously exposed, and to correlate it to other exposures within a much broader region (Sarna-Wojcicki, 1971, 1976, 2000). Chemical analysis of the volcanic glass indicates that a $\sim 15$-m-thick volcanic breccia that lies near the base of the Wilson Grove Formation to the north of Mark West Creek, and outcrops at the extreme northwest part of this formation, is the same as the Roblar tuff, contrary to Travis' (1952) inference that these two deposits were of different origin. However, Travis (1952) was correct in assuming that the source of the Roblar tuff was situated to the northeast of the Wilson Grove Formation, as the tuff thickens and coarsens in that direction. Pumice clasts as large as $10 \mathrm{~cm}$ in diameter are present in the tuff breccia situated on the north side of Mark West Creek. This suggests that the source was probably close, most likely within the older part of the Sonoma Volcanics to the east. The actual source vent has not been determined and may be buried by younger deposits beneath the Santa Rosa Plain to the east of the coarse breccia on the northside of Mark West Creek.
Using its chemical composition, the Roblar tuff in the Wilson Grove Formation has now been correlated with a number of localities in the northern and central Coast Ranges of California, as well as within sediments of the eastern Pacific Ocean (fig. 2; table 4). Specifically (proceeding from the northwest to the southeast), the tephra is present in sediments of the Delgada Fan offshore of northern California, where it was encountered in Deep-Sea Drilling Program (DSDP) hole 34 with the base of the ash at $118.90 \mathrm{~m}$ beneath the sediment/water interface.

The Delgada Fan was fed through two deep-ocean canyons, the Noyo and Delgada Canyons, and the heads of these canyons abut the San Andreas Fault Zone that lies just to the east. Sarna-Wojcicki (1992) proposed that the Delgada Canyon and fan were juxtaposed opposite the present area of the Wilson Grove Formation at the time of the eruption of the Roblar tuff, that the Roblar tuff was transported across the San Andreas Fault by streams and ocean currents into the Delgada Canyon shortly after the eruption, and that the area to the west of the Wilson Grove Formation (the Pacific Plate) was offset by right lateral movement on the fault to the northwest, a distance of about $230 \mathrm{~km}$, from the Wilson Grove Formation on the east, which is situated on the North American Plate (fig. 2).

The Roblar tuff is also present to the east of the Wilson Grove Formation, at several sites within the Sonoma Volcanics near Santa Rosa, and to the southeast near Cannon Road and Sears Point, Sonoma County, within the Petaluma Formation. Farther to the southeast, across the Rodgers Creek-Hayward Fault Zone, the Roblar tuff is present within the Contra Costa Group near the town of San Pablo, stratigraphically below the $\sim 5.4-5.2$ Ma Pinole Tuff. Farther to the southeast, southeast of the town of Lafayette, the Roblar tuff has been identified near the top of the Contra Costa Group. To the east and southeast of the latter locality, the Roblar tuff has been identified at several sites within the informal Green Valley formation of Conduit (1938) (also sometimes called the Sycamore Canyon formation of Graymer and others (2002), Tedford and others, 2004, and Sarna-Wojcicki and others (2011); Sycamore Canyon Formation has previous been use in Puente Hills, Los Angeles Basin California), where it is present below the Pinole Tuff, and the latter, in turn, below the Lawlor Tuff (4.83 Ma; Sarna-Wojcicki and others, 2011). The Roblar tuff is also present about $200 \mathrm{~km}$ farther to the southeast, in the marine Etchegoin Formation within the Coalinga Anticline, just east of the town of Coalinga in the San Joaquin Valley (fig. 3; table 4).

\section{Biostratigraphy}

Molluscan biostratigraphy supports the age for the Wilson Grove Formation at Bloomfield Quarry determined above but does not help refine it further. Four extinct molluscan species reported by Zullo and Guruswami-Naidu (1982) from 


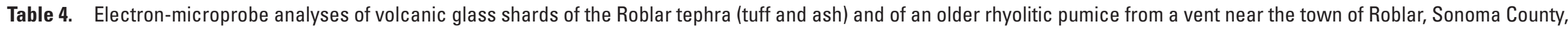
California, inferred to have been the source vent of the Roblar tephra (Travis, 1952).

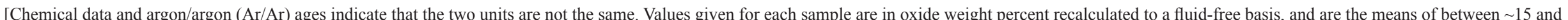

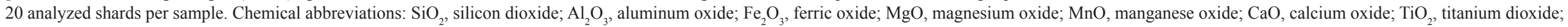

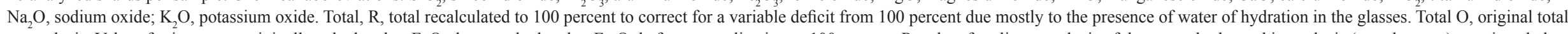

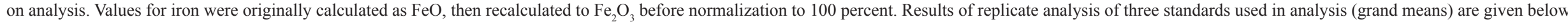

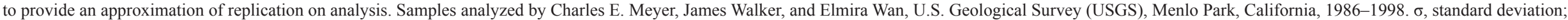
fm., formation; DSDP, Deep Sea Drilling Project; NA, not applicable]

\begin{tabular}{|c|c|c|c|c|c|c|c|c|c|c|c|c|}
\hline Roblar tephra locality & $\begin{array}{l}\text { Number of samples and } \\
\text { standard deviation }(1 \sigma)\end{array}$ & $\mathrm{SiO}_{2}$ & $\mathbf{A l}_{2} \mathbf{O}_{3}$ & $\mathrm{Fe}_{2} \mathrm{O}_{3}$ & MgO & MnO & $\mathrm{CaO}$ & $\mathrm{TiO}_{2}$ & $\mathrm{Na}_{2} \mathrm{O}$ & $\mathrm{K}_{2} \mathrm{O}$ & Total 0 & Total R \\
\hline $\begin{array}{l}\text { 1. Northeast Pacific Ocean, DSDP-34-8-6 } \\
\text { (Delgada Fan) }\end{array}$ & 1 sample & 75.04 & 13.61 & 1.49 & 0.07 & 0.03 & 0.60 & 0.14 & 4.45 & 4.57 & 93.07 & 100.00 \\
\hline \multirow{2}{*}{$\begin{array}{l}\text { 2. Wilson Grove Fm. (includes Bloomfield } \\
\text { Quarry locality) }\end{array}$} & Mean of 9 samples & 75.03 & 13.62 & 1.48 & 0.06 & 0.03 & 0.58 & 0.13 & 4.44 & 4.62 & 92.69 & 100.00 \\
\hline & Standard deviation & 0.18 & 0.19 & 0.03 & 0.01 & 0.01 & 0.02 & 0.02 & 0.11 & 0.16 & 0.32 & 0.00 \\
\hline $\begin{array}{l}\text { 3. Southeast of Roblar (Wilson Grove Fm. } \\
\text { (?)) }\end{array}$ & Mean of 2 samples & 75.52 & 13.44 & 1.46 & 0.07 & 0.02 & 0.59 & 0.13 & 3.90 & 4.88 & 92.74 & 99.99 \\
\hline \multirow{2}{*}{$\begin{array}{l}\text { 4. Northwest Sonoma Volcanics (including } \\
\text { Petaluma Fm. (?)) }\end{array}$} & Mean of 8 samples & 75.44 & 13.51 & 1.45 & 0.07 & 0.03 & 0.60 & 0.12 & 4.14 & 4.66 & 94.47 & 100.00 \\
\hline & Standard deviation & 0.34 & 0.21 & 0.09 & 0.01 & 0.01 & 0.03 & 0.01 & 0.29 & 0.19 & 0.96 & 0.01 \\
\hline \multirow{2}{*}{$\begin{array}{l}\text { 5. Southwest Sonoma Volcanics (Petaluma } \\
\text { Fm.) }\end{array}$} & Mean of 5 samples & 75.62 & 13.76 & 1.51 & 0.07 & 0.03 & 0.59 & 0.11 & 4.49 & 3.83 & 93.22 & 100.00 \\
\hline & Standard deviation & 0.38 & 0.08 & 0.04 & 0.00 & 0.01 & 0.02 & 0.01 & 0.20 & 0.63 & 1.33 & 0.01 \\
\hline \multirow{2}{*}{$\begin{array}{l}\text { 6. Berkeley Hills block (Contra Costa } \\
\text { Group) }\end{array}$} & Mean of 4 samples & 75.62 & 13.74 & 1.47 & 0.06 & 0.03 & 0.57 & 0.11 & 3.64 & 4.59 & 92.61 & 100.00 \\
\hline & Standard deviation & 0.83 & 0.21 & 0.03 & 0.02 & 0.01 & 0.04 & 0.02 & 0.53 & 0.89 & 2.63 & 0.00 \\
\hline \multirow{2}{*}{$\begin{array}{l}\text { 7. Block } 5 \text { of Mount Diablo (Green Valley or } \\
\text { Sycamore fm.) }\end{array}$} & Mean of 4 samples & 75.46 & 13.48 & 1.48 & 0.07 & 0.02 & 0.58 & 0.11 & 3.93 & 4.88 & 91.43 & 100.00 \\
\hline & Standard deviation & 0.19 & 0.13 & 0.03 & 0.01 & 0.00 & 0.02 & 0.01 & 0.35 & 0.39 & 0.71 & 0.01 \\
\hline 8. Coalinga Anticline (Etchegoin Fm.) & 1 sample & 75.89 & 13.59 & 1.51 & 0.06 & 0.01 & 0.58 & 0.11 & 5.01 & 3.25 & 92.85 & 100.01 \\
\hline \multicolumn{13}{|c|}{ Roblar tephra, average composition } \\
\hline & Grand mean, 35 samples & 75.41 & 13.59 & 1.47 & 0.07 & 0.03 & 0.58 & 0.12 & 4.20 & 4.52 & 93.09 & 100.00 \\
\hline & Standard deviation & 0.43 & 0.19 & 0.05 & 0.01 & 0.01 & 0.03 & 0.01 & 0.41 & 0.54 & 1.42 & 0.01 \\
\hline \multicolumn{13}{|c|}{ Reference standards used in analysis and replication (values on analysis; not normalized to 100 percent) } \\
\hline \multirow{2}{*}{$\begin{array}{l}\text { USGS obsidian glass standard RLS } 132 \text {, } \\
\text { a homogenous glass from near Puebla, } \\
\text { Mexico }\end{array}$} & Grand mean, 94 samples & 75.42 & 75.42 & $2.115^{1}$ & 0.06 & 0.150 & 0.11 & 0.19 & 4.578 & 4.39 & 98.56 & NA \\
\hline & Standard deviation & 0.69 & 0.15 & 0.038 & 0.02 & 0.01 & 0.02 & 0.02 & 0.516 & 0.12 & 0.71 & NA \\
\hline \multirow{2}{*}{$\begin{array}{l}\text { USGS glass standard GSC, a synthetic glass } \\
\text { standard made for the USGS by Corning } \\
\text { Glass Co. (Myers and others, 1976) }\end{array}$} & Grand mean, 77 samples & 61.99 & 14.22 & 6.276 & 3.85 & 0.027 & 5.0 & 0.01 & 4.028 & 3.59 & 98.978 & NA \\
\hline & Standard deviation & 0.31 & 0.31 & 0.169 & 0.12 & 0.007 & 0.1 & 0.01 & 0.119 & 0.09 & 0.41 & NA \\
\hline \multirow{2}{*}{$\begin{array}{l}\text { USGS mineral standard, andesine plagio- } \\
\text { clase } \mathrm{An}_{40}\end{array}$} & Grand mean, 60 samples & 57.91 & 27.35 & 0.029 & 0 & 0.008 & 8.36 & 0.01 & 6.88 & 0.02 & 100.57 & NA \\
\hline & Standard deviation & 0.51 & 0.31 & 0.009 & 0 & 0.005 & 0.09 & 0.01 & 0.368 & 0.01 & 0.78 & NA \\
\hline
\end{tabular}

${ }^{1}$ Iron in standard RLS 132 is reported as $\mathrm{FeO}$. 
the basal unit [Arca santamariensis (provisionally identified), Crenomytilus coalingensis (provisionally identified), Swiftopecten parmeleei, and Tresus pajaroanus], two from the upper sand unit (Tresus pajaroanus and Crepidula princeps) and an additional gastropod and bivalve from the quarry in collections at the CAS [Caesia grammatus (provisionally identified) and Chlamys hodgei (provisionally identified)] are also extinct. Most of these taxa have overlapping teil zones within the "Jacalitos" California provincial molluscan stage (CPMS); however, Caesia grammatus (provisionally identified) has previously been restricted to the Pliocene (uppermost "Etchegoin" and "San Joaquin" CPMSs), although it is not confidently identified so it is not used to determine the age of the unit or to have it stratigraphic distribution modified.

\section{Age Summary}

The data presented above indicate that the lower part (below the Roblar tuff) of the Wilson Grove Formation is late Miocene in age, between $<9.27 \pm 0.06 \mathrm{Ma}$ and $>6.203 \pm 0.011$ $\mathrm{Ma}$, whereas in its upper part (above the Roblar tuff) an age range between $6.203 \pm 0.011 \mathrm{Ma}$ to possibly as young as $>2.6 \mathrm{Ma}$ (late Pliocene; Powell and others, 2004) is determined. This age range includes the "Jacalitos" CPMS for the lower unit to possibly the "San Joaquin" CPMS for the upper unit and overall overlaps the upper part of the Tortonian and lower part of the Messinian to the Piacenzian stages of the International Chronostratigraphic Chart (International Commission on Stratigraphy, 2012).

\section{Paleontology}

The fauna from the Bloomfield Quarry exposures of the Wilson Grove Formation consists of 77 taxa -4 brachiopods, 42 mollusks ( 28 bivalves and 14 gastropods), 6 arthropods ( 1 crab, 1 shrimp, and 4 barnacles), and 25 vertebrates ( 3 sharks, 1 ray, 8 bony fishes, 9 marine mammals, and 4 birds) (table 1 ; see the appendix for taxonomic notes). Not documented during this study are a few bryozoans, fragmentary fish bones, and other possible biologic remains in the CAS and the University of California Museum of Paleontology (UCMP) collections, most of which are not well enough preserved for more precise identification.

The paleoenvironmental interpretation of the brachiopods is a shallow subtidal to rocky intertidal environment, with some, but relatively little, transport of individuals away from their in-life position to the site of deposition, very similar to that described for mollusks, below. This interpretation is supported by several lines of evidence. The depth and habitat ranges for extant representatives of these species, and closely related congeners, is shallow subtidal to intertidal; all require a hard substrate (rocky substrate or shells of other organisms) for attachment by a pedicle and live gregariously in crowded conditions of relatively high abundance. Extant articulated brachiopod valves from dead individuals that remain on the substrate will begin to degrade after only a few weeks of exposure from decay of organic material surrounding the "fibers" making up the mineralized secondary shell (Kowalewski and LaBarbera, 2004). The nature of the preservation of individual valves, and relative proportions of still-articulated individuals and disarticulated valves, indicates relatively rapid burial shortly after death, with little prolonged exposure on the seafloor. Rapid deposition is also indicated by the three-dimensional orientation of disarticulated valves within the sandstone matrix - either as unoriented individual dorsal valves of inarticulated brachiopods floating in matrix or as clumped or imbricated dorsal or ventral valves of articulated brachiopods; relatively strong, bidirectional forces generated near wave base could result in a deposit of this type.

Mollusks and the geologic setting indicate a paleoenvironment similar to that described above for the Brachiopoda. Mollusks collected from the basal conglomerate were analyzed by Barry Roth (in Zullo and Guruswami-Naidu, 1982) and interpreted as representing a rocky intertidal or shallow subtidal environment exposed to moderate to heavy surf. A rocky substrate with adjacent sandy areas is indicated by the mollusks identified here supplementing the environmental interpretation of Roth (in Zullo and Guruswami-Naidu, 1982) cited above. In addition, the stratigraphic position of the underlying Franciscan Complex basement indicates very shallow water depths in agreement with Zullo and GuruswamiNaidu (1982). Using extant mollusks ( $n=14)$, the overlapping latitudinal ranges show that the bivalve genera Anadara and Arca today occur only south of the current latitude of the fossil locality today, whereas the others are consistent with that latitude. However, both genera are known from further north than Sonoma County during the Miocene, so the faunal composition is consistent with the latitude of the fossil locality in the Miocene.

The ichthyofauna is indicative of the relatively recent northeastern Pacific assemblages that originated in the late Miocene with the evolution of a temperate upwelling regime (Long, 1994; Hobson 2006), and each of the family and genera of bony fishes collected at this site, as well as those sharks and ray identified to the species level, are still found in California marine waters. The most important aspect of the teleost fauna is that many represent early records, or even ancestral forms, of later species found in California waters today. These fossil teleosts are taxa that today are found in nearshore habitats, such as kelp beds, seagrass meadows, sand flats, and muddy bottoms (Allen and Pondella, 2006). Most of these species are coastal, or have ranges that extend into littoral waters, but due to the wide latitudinal and bathymetric distributions of some species, they are not especially indicative of a more precise paleoecology of the locality. Several species, such as the shark Isurus oxyrinchus and the bonito Sarda sp. tend to be associated with warmer temperate waters, but often extend into cooltemperate waters when waters are seasonally warm or during warmer El Niño events. This indicates that the local marine 
climate of this depositional environment was slightly warmer than the adjacent coast today or that these specimens were deposited during periods of seasonal or abnormal warm-water intrusion (Long, 1992, 1993b).

Barnes (1976 [1977]) reported the first marine mammals from the Wilson Grove Formation, including the lipotid dolphin Parapontoporia sternbergi and the balaenid right whale Balaenula sp. However, these specimens have not yet been described. To that list can be added Dusignathus santacruzensis, Gomphotaria pugnax, cf. Pontolis, an unidentified odobenine walrus, and an unidentified sirenian. The marine mammal assemblage from Bloomfield Quarry represents the most diverse walrus assemblage yet reported in the world. It includes three dusignathine walruses and an indeterminate odobenine walrus. The cetacean fossils are less diagnostic and only indicate the presence of unidentified odontocetes and mysticetes; more diagnostic cetacean material including skulls, jaws, and petrosals are known from other localities in the Wilson Grove Formation that are not yet described, including a pygmy mysticete a few kilometers to the east (Allen and Holland, 1999; Powell and others, 2004). Notably lacking from the marine mammal assemblage are otariid fur seals, which are known from other late Miocene strata such as the Purisima Formation in central California (Repenning and Tedford, 1977), as well as localities stratigraphically higher in the Wilson Grove Formation. Again, these other specimens from the Wilson Grove Formation have yet to be described. The pinniped assemblage is similar to that of the basal Purisima Formation near Santa Cruz, where Gomphotaria and Dusignathus are preserved alongside odobenine walruses and otariid fur seals. However, no other strata from the eastern North Pacific preserve even two of these three dusignathine taxa together.

Bird remains have not been reported previously from the Wilson Grove Formation, and a minimum of only two species can be attributed to the avifauna from Bloomfield Quarry based on the material presently available. However, conclusions regarding the composition of the Wilson Grove Formation avifauna are necessarily preliminary because the quantity of fossil remains ( $n=6$ specimens) is very limited. Nonetheless, the species represented by the material described herein (Mancallinae indeterminate and cf. Uria brodkorbi) are consistent with that documented for other Miocene marine avifaunas from the eastern Pacific Ocean basin (Warheit, 1992, 2002). Uria and Mancallinae co-occur in the middlelate Miocene "Monterey" Formation of Orange County, California (Howard, 1966, 1978) and the late Miocene to early Pliocene San Mateo Member of the Capistrano Formation of San Diego County, California. However, Mancallinae remains have not been reported from the type locality of Uria brod$k o r b i$, the late Miocene to early Pliocene diatomite deposits of the Sisquoc Formation in Santa Barbara, County, California (Howard, 1981).

Nearly every deposit that has produced pan-alcid remains has been interpreted as the result of moderate to shallow depth deposition of sediments associated with cold-water upwelling (Deméré, 1983; Olson and Rasmussen, 2001; Smith, 2011; Smith and Clarke, 2011; Smith, 2013a,b). This interpretation is in agreement with the intertidal to shallow subtidal water depths indicated by the molluscan fauna and the relatively shallow (that is, $<10 \mathrm{~m}$ ) depositional setting proposed by Roth in Zullo and Guruswami-Naidu (1982).

\section{References Cited}

Adams, H., and Adams, A., 1853-1858, The genera of Recent Mollusca, arranged according to their organization: London, p. vi-xi, p. 1-484; v. 2, p. 1-661; 3, pls. 1-138 [dating of parts from Keen, 1971, p. 661].

Addicott, W.O., 1965, Some western American Cenozoic gastropods of the genus Nassarius: U.S. Geological Survey Professional Paper 503-B, p. B1-B24. [Also available at https://pubs.er.usgs.gov/publication/pp503B.]

Addicott, W.O., 1970, Miocene gastropods and biostratigraphy of the Kern River area, California: U.S. Geological Survey Professional Paper 642, 174 p. [Also available at https:// pubs.er.usgs.gov/publication/pp642.]

Addicott, W.O., 1976a, Molluscan paleontology of the lower Miocene Clallam Formation, northwestern Washington: U.S. Geological Survey Professional Paper 976, 44 p. [Also available at https://pubs.er.usgs.gov/publication/pp976.]

Addicott, W.O., 1976b, Neogene molluscan stages of Oregon and Washington, in Fritsche, A.E., TerBest, H., Jr., and Wornardt, W.W., eds., The Neogene symposium: Pacific Section, Society of Economic Paleontologists and Mineralogists, p. 95-115.

Addicott, W.O., 1980, Miocene stratigraphy and fossils, Cape Blanco, Oregon: Oregon Geology, v. 42, p. 87-97.

Addicott, W.O., 1981, Significance of pectinids in Tertiary biochronology of the Pacific Northwest, chap. P, in Armentrout, J.M., ed., Pacific Northwest Cenozoic biostratigraphy: Geological Society of America Special Paper 184, p. 17-37.

Addicott, W.O., 1983, Biostratigraphy of the marine Neogene sequence at Cape Blanco, southwestern Oregon: U.S. Geological Survey Professional Paper 774-G, p. G1-G20. [Also available at https://pubs.er.usgs.gov/publication/pp774G.]

Addicott, W.O., Barron, J.A., and Miller, J.W., 1978, Marine late Neogene near Santa Cruz, California, in Addicott, W.O., ed., Neogene biostratigraphy of selected areas in the California Coast Range-Field conference on marine Neogene of California, International Geological Correlation Programme, Project 114, June 21-24, 1978: U.S. Geological Survey Open-File Report 78-446, p. 97-109. [Also available at https://pubs.er.usgs.gov/publication/ofr78446.] 
Adegoke, O.S., 1969, Stratigraphy and paleontology of the marine Neogene formations of the Coalinga region, California: University of California Publications in Geological Sciences, v. 80, 241 p.

Agassiz, L., 1853, Extraordinary fishes from California, constituting a new family, described by L. Agassiz: American Journal of Science and the Arts, series 2, v. 16, no. 48, p. 380-390.

Allen, J.A., 1880, History of North American pinnipeds-A monograph of the walruses, sea-lions, sea-bears and seals of North America: U.S. Geological and Geographic Survey, Miscellaneous Publications-No. 12, 785 p., https://doi. org/10.5962/bhl.title.1921.

Allen, J.E., 1945, Geology of the San Juan Bautista Quadrangle, California: University of California, Berkeley, Ph.D. dissertation, $94 \mathrm{p}$.

Allen, J.R., 2003, Stratigraphy and tectonics of Neogene strata, northern San Francisco bay area: San Jose, Calif., San Jose State University, Master's thesis, 190 p.

Allen, J.R., and Holland, P.J., 1999, Description and interpretation of the pebbly sandstone facies of the Wilson Grove Formation, Marin County, California-A possible sediment for the Delgada Fan during late Miocene-early Pliocene time: Geological Society of America Abstracts with Programs, v. 31 , no. 6 , p. A33.

Allen, J.R., Barnes, L.G., and Holland, P.J., 1999, A small species of fossil mysticete whale (Cetacea: Balaenopteridae) from the late Miocene to early Pliocene Wilson Grove Formation, Sonoma County, California: PaleoBios, v. 19, supplement to no. 1, p. 1.

Allen, L.G., and Pondella, D.J., 2006, Ecological classification, in Allen, L.G., Pondella, D.J., and Morn, M.H., eds., The ecology of marine fishes - California and adjacent waters: Berkeley, University of California Press, p. 81-113.

Allen, M., 1990, The biological environment of the California halibut, Paralichthys californicus, chap. 9 in Haugen, C., ed., The California halibut, Paralichthys californicusResource and fisheries - 4: Sacramento, California Department of Fish and Game, Fish Bulletin 174, p. 7-29.

Andrews, K.S., Williams, G.D., Farrer, D., Tolimieri, N., Harvey, C.J., Bargmann, G., and Levin, P.S., 2009, Diel activity patterns of sixgill sharks, Hexanchus griseus - The ups and downs of an apex predator: Animal Behaviour, v. 78 , p. $525-536$.

Armentrout, J.M., 1981, Correlation and age of Cenozoic chronostratigraphic units in Oregon and Washington: Geological Society of America Special Paper 184, p. 137-148.

Arnold, R.A., 1903, The paleontology and stratigraphy of the marine Pliocene and Pleistocene of San Pedro, California: California Academy of Sciences, Memoir 3, 420 p.
Arnold, R.A., 1907, New and characteristic species of fossil mollusks from the oil-bearing Tertiary formations of southern California: Proceedings of the U.S. National Museum, v. XXXII, p. 525-546.

Arnold, R.A., 1908, Descriptions of new Cretaceous and Tertiary fossils from the Santa Cruz Mountains, California: U.S. National Museum Proceedings, v. 34, p. 345-390.

Arnold, R.A., 1909 [1910], Paleontology of the Coalinga district, Fresno and Kings Counties, California: U.S. Geological Survey Bulletin 396, 173 p. [Also available at https:// pubs.er.usgs.gov/publication/b396.]

Ayres, W.O., 1859, Descriptions of fishes: Proceedings of the California Academy of Sciences, 1st series, v. 2, p. 25-32.

Bailey, T.R., McArthur, J.M., Prince, H., and Thirlwall, M.F., 2000, Dissolution methods for strontium isotope stratigraphy, whole rock analysis: Chemical Geology, v. 167, p. 313-319.

Baldwin, W.J., 1961, First record of three northern fishes from the upper Gulf of California: Copeia 1961, p. 475-476.

Barnes, L.G., 1971, Imagotaria (Mammalia: Otariidae) from the late Miocene Santa Margarita Formation near Santa Cruz, California: PaleoBios, no. 11, 10 p.

Barnes, L.G., 1976 [1977], Outline of eastern North Pacific fossil cetacean assemblages: Systematic Zoology, v. 25, p. 321-343, https://doi.org.10.2307/2412508.

Barnes, L.G., and Raschke, R.E., 1991, Gomphotaria pugnax, a new genus and species of late Miocene dusignathine otariid pinniped (Mammalia: Carnivora) from California: Natural History Museum of Los Angeles County Contributions in Science, no. 426, 27 p.

Barnes, L.G., Domning, D.P., and Ray, C.E., 1985, Status of studies on fossil marine mammals: Marine Mammal Science, v. 1, p. 15-53.

Bateson W., 1885, The later stages in the development of Balanoglossus kowalevskii, with a suggestion as to the affinities of the Enteropneusta: Quarterly Journal of Microscopical Science, v. 25, p. 81-122.

Baumel, J., and Witmer, L., 1993, Osteologica, in Baumel, J.J., King, A.S., Breazile, J.E., Evans, H.E., and Vanden Berge, J.C., eds., Handbook of avian anatomy-nomina anatomica avium, 2nd ed.: Publications of the Nuttall Ornithology Club, no. 23, p. 45-132.

Baumgartner, T.R., Soutar, A., and Ferreira-Bartrina, V., 1992, Reconstructions of the history of Pacific sardine and northern anchovy populations over the past two millennia from sediments of the Santa Barbara Basin, California: California Cooperative Oceanic Fisheries Investigations, report, no. 33, p. 24-40. 
Beecher, C.E., 1893, Revision of the families of loop-bearing Brachiopoda: Transactions of the Connecticut Academy of Arts and Sciences, v. 9, p. 276-391.

Berg, L.S., 1958, System der rezenten und fossilen Fischartigen und Fische: Berlin, Deutscher Verlag Wissenschaft, 310 p.

Berkoff, M., and Barnes, L.G., 1998, The evolution of the dusignathines-Pseudo-walruses of the late Miocene: PaleoBios, v. 18, supplement to number 3, 2 p.

Bernardi, G., and Bucciarelli, G., 1999, Molecular phylogeny and speciation of the surfperches (Embiotocidae, Perciformes): Molecular Phylogenetics and Evolution v. 13, no. 1, p. 77-81.

Bezore, S.P., Koehler, R.D., and Witter, R.C., 2003, Geologic map of the Two Rock 7.5' quadrangle, Sonoma County, California-A digital database: California Geological Survey, accessed January 2014, at ftp://ftp.consrv.ca.gov/pub/dmg/ rgmp/Prelim_geo_pdf/Two_Rock_prelim.pdf_x.

Bezore, S.P., Randolph-Loar, C.E., and Witter, R.C., 2002, Geologic map of the Petaluma 7.5' Quadrangle, Sonoma and Marin counties, California-A digital database: California Geological Survey, accessed July 2015, at ftp://ftp. consrv.ca.gov/pub/dmg/rgmp/Prelim_geo_pdf/petaluma_ layout_highres.pdfx.

Blainville, H.M.D. de., 1814, Mémoíre sur la classification méthodique des animaux mollusques, et établissement d'une nouvelle consideration pour y parvenir: Sciences par la Société Philomatique de Paris Bulletin, Zoologie (1814), p. $175-180$.

Bleeker, P., 1859, Negende bijdrage (I) tot de kennis der vischfauna van Banka: Natuurkundig Tijdschrift voor Nederlandsch Indië, v. 18, p. 359-378.

Boessenecker, R.W., 2007, New records of fossil fur seals and walruses (Carnivora: Pinnipedia) from the late Neogene of northern California: Vertebrate Paleontology Journal, v. 27 (supplement to number 3), p. 50A.

Boessenecker, R.W., 2011, Herpetocetine (Cetacea: Mysticeti) dentaries from the upper Miocene Santa Margarita Sandstone of central California: PaleoBios, no. 30, 12 p.

Boessenecker, R.W., 2013, A new marine vertebrate assemblage from the late Neogene Purisima Formation in central California, part II - pinnipeds and cetaceans. Geodiversitas, v. 35, p. $815-940$.

Bonaparte, C.L., 1838, Synopsis vertebratorum systematis: Nouovi Annali delle Scienze Naturali Bologna, series 1, p. 105-133.

Bonnaterre, J.P., 1788, Ichthyologie-Tableau encyclopédique et méthodique des trois règnes de la nature: Paris, $215 \mathrm{p}$.
Born, I., 1778, Index rerum naturalium musei caesarei vindobonensis-Part I, Testacea: Vienna, $458 \mathrm{p}$.

Bouchet, P., Rocroi, J.-P., Bieler, R., Carter, J.G., and Coan, E.V., 2010, Nomenclator of bivalve families with a classification of bivalve families iles: Malacologia, v. 52, no. 2, p. $112-184$.

Bouchet, P., and Rocroi, J.-P., eds., with classification by Fryda, J., Hausdorf, B., Ponder, W., Valdés, A., and Warén, A., 2005, Classification and nomenclator of gastropod families: Malacologia, v. 47, 397 p.

Bouetel, V., and Muizon, C., de, 2006, The anatomy and relationships of Piscobalaena nana (Cetacea, Mysticeti), a Cetotheriidae s.s. from the early Pliocene of Peru: Geodiversitas, v. 28, p. 319-395.

Bowdich, T.E., 1821, An analysis of the natural classifications of Mammalia for the use of students and travellers: Paris, J. Smith, $115 \mathrm{p}$.

Brand, U., and Veizer, J., 1980, Chemical diagenesis of a multicomponent carbonate system, 1 -Trace elements: Journal of Sedimentary Petrology, v. 50, p. 155-264.

Brandt, J.F., 1872, Bericht über den bereits vollendeten, druckfertigen theil seiner untersuchungen über die fossilen and subfossilen Cetaceen Europas: Compte rendu de l'Académie impériale des Sciences de St. Pétersbourg, v. 17, p. 407-408.

Brisson, M.J., 1762, Regnum animale in classes IX distributum sive synopsis methodica: Paris, Jean-Baptiste Bauche, $296 \mathrm{p}$.

Broderip, W.J., 1832-1833, Characters of new species of Mollusca and Conchifera, collected by Mr. Cuming: Proceedings of the Zoological Society of London, for 1832, p. 25-33, 50-61, 104-108, 124-126, 173-179, 194-202 [some of the species cited in these pages were described by G.B. Sowerby, I]. [Also available at https://www.biodiversitylibrary.org/bibliography/44963\#/summary.]

Broderip, W.J., 1835, Descriptions of some new species of Cuvier's family of Brachiopoda: Zoological Society of London Proceedings, v. 1, p. 141-144.

Brodkorb, P., 1967, Catalogue of fossil birds-Part 3 (Ralliformes, Ichthyornithiformes, Charadriiformes): Florida State Museum Bulletin, Biological Sciences, v. 11, p. 99-220.

Burch, J.Q., 1942, Brachiopoda: Conchological Club of Southern California, May 5, 1942, p. 10.

Burke, W.H., Denison, R.E., Hetherington, E.A., Koepnick, R.B., Nelson, H.F., and Otto, J.B., 1982, Variation of seawater ${ }^{87} \mathrm{Sr} r{ }^{86} \mathrm{Sr}$ throughout Phanerozoic time: Geology, v. 10, p. 516-519. 
California Geological Survey, 2010, Geologic Map of California (2010): California Geological Survey interactive map, scale of 1:750,000, accessed November 2016, at https:// maps.conservation.ca.gov/cgs/gmc/.

Campbell, C.A., and Valentine, J.W., 1979, Morphological adaptation to climate-Nucella lamellosa in the California Pleistocene: Geological Society of America, Abstracts with Program, v. 11, no. 3, p. 72.

Campbell, R.B., 1929, Bibliography of otoliths: Society of Economic Mineralogists and Paleontologists Special Publication, v. 1, $35 \mathrm{p}$.

Cappetta, H., 2012, Chondrichthyes; Mesozoic and Cenozoic Elasmobranchii-Teeth, in Schultze, H.-P., ed., Handbook of Paleoichthyology, v. 3E: Munich, Verlag Dr. Friedrich Pfeil, 512 p.

Carlson, S.J., 1989, The articulate brachiopod hinge mechanism-Morphological and functional variation: Paleobiology, v. 15, p. 364-386.

Carpenter, P.P., 1864, Supplementary report on the present state of our knowledge with regard to the Mollusca of the West Coast of North America: British Association for the Advancement of Science, Report for 1863, p. 517-686.

Clark, A., 1931, The cool-water Timms Point Pleistocene horizon at San Pedro, California: San Diego Society of Natural History Transaction, v. 7, p. 25-42.

Clark, B.L., 1915, Fauna of the San Pablo Group of middle California: University of California Publications, Department of Geology Bulletin, v. 8, p. 385-572.

Clark, B.L., 1918, The San Lorenzo series of middle California-A stratigraphic and paleontologic study of the San Lorenzo Oligocene series of the general region of Mount Diablo, California: University of California Publications, Department of Geology Bulletin, v. 11, p. 45-234.

Clark, B.L., 1943, Notes on California Tertiary correlations, in Jenkins, O.P., director, Geologic Formations and Economic Development of the Oil and Gas Fields of California: California Division of Mines Bulletin 118, pt. 2, p. 187-191

Clark, G.A., Jr., 1993, Termini situm et directionum partium corporis indicates, in King, A.S., Breazile, J.E., Evans, H.E., and Vanden Berge, J.C., eds., Handbook of Avian Anatomy_nomina anatomica avium, 2nd ed. J.J., Baumel, Cambridge: Publications of the Nuttall Ornithological Club, no. 23 , p. $1-5$.
Clark, J.C., 1981, Stratigraphy, paleontology, and geology of the central Santa Cruz Mountain, California Coast Ranges: U.S. Geological Survey Professional Paper 1168, 51 p. [Also available at https://pubs.er.usgs.gov/publication/ pp1168.]

Coan, E.V., Valentich Scott, P., and Bernard, F.R., 2000, Bivalve seashells of western North America-Marine bivalve mollusks from Arctic Alaska to Baja California: Santa Barbara Museum of Natural History Monograph 2, Studies in Biodiversity, no. 2, 764 p.

Cohen, D.M., Inada, T., Iwamoto, T., and Scialabba, N., 1990, FAO species catalogue, volume 10-Gadiform fishes of the world (Order Gadiformes)_-An annotated and illustrated catalog of cods, hakes, grenadiers and other gadiform fishes known to date: Food and Agriculture Organization of the United Nations, Fisheries and Aquaculture Department, FAO Fisheries Synopsis, v. 125, 442 p.

Collette, B.B., and Nauen, C.E., 1983, FAO species catalog, volume 2-Scombrids of the world - An annotated and illustrated catalogue of tunas, mackerels, bonitos and related species known to date: Food and Agriculture Organization of the United Nations, Fisheries and Aquaculture Department, FAO Fisheries Synopsis, v. 125, no. 2, 137 p.

Compagno, L.J.V., 1973, Interrelationship of living elasmobranch fishes, in Greenwood, P.H., Patterson, C., and Mies, R., eds., Interrelationship of Fishes: London, Academic Press, p. 15-61.

Compagno, L.J.V., 2001, Sharks of the world-An annotated and illustrated catalogue of shark species known to dateVolume 2, bullhead, mackerel and carpet sharks (Heterodontiformes, Lamniformes and Orectolobiformes): Food and Agriculture Organization of the United Nations, Fisheries and Aquaculture Department, FAO Species Catalogue for Fishery Purposes, v. 1, 269 p.

Conrad, T.A., 1837, Description of new marine shells from upper California, collected by Thomas Nuttall, Esq.: Academy of Natural Sciences of Philadelphia Journal, v. 7, p. 227-268.

Conrad, T.A., 1849, Fossils from northwestern America, in Dana, J.D., Geology, U.S. Exploring Expedition, during the years $1838,1839,1840,1841,1842$, under the command of Charles Wilkes, U.S.N.: Philadelphia, v. 10, appendix, p. 722-728 [reprinted in Dall, W. H., 1909, p.152-156.] 
Conrad, T.A., 1855, Report of Mr. T.A. Conrad on the fossil shells collected in California by Wm. P. Blake, geologist of the expedition, under the command of Lieutenant R.S. Williamson, United States Topographical Engineers, 1853, in Blake, W.P., Appendix to preliminary geological report of W.P. Blake, in Williamson, R.S., ed., Reports of explorations and surveys, to ascertain the most practicable and economical route for a railroad from the Mississippi River to the Pacific Ocean: Washington, D.C., War Department, 33d Congress, 1st session, House of Representatives Ex. Doc. No. 129, p. 5-20 [reprinted in Dall, W.H., 1909, p. 163-171]. [Also available at http://olivirv.myspecies.info/ sites/olivirv.myspecies.info/files/Description $\% 20$ of $\% 20$ the $\% 20$ fossils $\% 20$ and $\% 20$ shells $\% 20$ collected $\% 20$ in $\% 20$ Calam\%20Phipps\%29\%20\%26\%20Conrad\%2C\%20 T.A.\%20\%28Timothy\%20Abbott\%20-\%201803-1877\%29. pdf.]

Conrad, T.A., 1856 [1857], Descriptions of new fossil shells, in Blake, W.P. Part II, Geological report; routes in California, to connect with the routes near the thirty-fifth and thirty-second parallels, explored by Lieut. R.S. Williamson, corps topographical engineers, in 1853, in Williamson, R.S., ed., Reports of explorations and surveys, to ascertain the most practicable and economical route for a railroad from the Mississippi River to the Pacific Ocean: Washington, D.C., War Department, 33d Congress, 2d session, House of Representatives Ex. Doc. No. 91, part 2, p. 317-329 [separate in 1856].

Conduit, C., 1938, The San Pablo flora of west central California: Carnegie Institution of Washington, Contributions to Paleontology, v. 476, p. 217-268.

Conrad, T.A., 1857, Descriptions of new West Coast shells. American Journal of Conchology, v. 3, p. 192-193.

Cummings, J.C., Touring, R.M., and Brabb, E.E., 1962, Geology of the northern Santa Cruz Mountains, California, in Bowen, O.E., ed., Geologic guide to the gas and oil fields of northern California: California Division of Mines and Geology Bulletin 181, p. 179-220.

Cuvier, G., 1795, Second Mémoire sur l'organisation et les rapports des animaux à sang blanc, dans lequel on traite de la structure des Mollusques et de leur division en ordre, lu à la société d'Histoire Naturelle de Paris, le 11 prairial an troisième [30 May 1795]: Magazin Encyclopédique, ou Journal des Sciences, des Lettres et des Arts, 1795 [1. année], no. 2, p. 433-449. [Also available at http://www. biodiversitylibrary.org/page/6736775.]

Cuvier, G., 1817, Le règne animal distribué d'après son organisation pour servir de base à l'histoire naturelle des animaux et d'introduction à l'anatomie comparée-Les reptiles, les poissons, le mollusques et les annélides: Paris, Chez Déterville, Libraire, ed. 1, v. 2, 532 p., https://doi.org/10.5962/ bhl.title.41460.
Cuvier, G., 1829, Le règne animal, distribué d'après son organisation, pour servir de base à l'histoire naturelle des animaux et d'introduction à l'anatomie comparée: Paris, Chez Déterville, Libraire, ed. 2, v. 2, 406 p., https://doi. org/10.5962/bhl.title.49223.

Cuvier, G., and Valenciennes, M., 1828-1849, Histoire naturelle des poissons: Paris, Chez F. G. Levrault, 22 v., https://doi.org/10.5962/bhl.title.7339.

d'Orbigny, A., 1837-1847, Voyage dans l'Amerique Meridionale-Mollusques: Paris, v. 5, 758 p., https://doi. org/10.5962/bhl.title.85973.

d'Orbigny, A., 1847, Considérations zoologiques et géologiques sur les Brachiopodes ou Palliobranches, parts 1-2: Comptes Rendus, Hebdomadaires des Séances de l'Académie des Sciences, v. 25, p. 193-195 and 266-269.

Dahl, E., 1956, Some Crustacean relationships, in Wingstrand, K.G., ed., Bertil Hanström; zoological papers in honour of his sixty-fifth birthday: Lund Zoological Institute, $p$. 138-147.

Dall, W.H., 1871, Descriptions of sixty new forms of mollusks from the West Coast of North America and north Pacific Ocean, with notes on others already described: American Journal of Conchology, v. 7, p. 93-160.

Dall, W.H., 1874, Notes on some Tertiary fossils from the California coast, with a list of the species obtained from a well at San Diego, California, with descriptions of two new species: California Academy of Sciences Proceedings, v. 5, p. 296-299.

Dall, W.H., 1891, Scientific results of explorations by the U.S. Fish Commission Steamer Albatross: U.S. National Museum Proceedings, v. 14, p. 173-191.

Dall, W.H., 1898, Contributions to the Tertiary fauna of Florida with especial reference to the Miocene silex beds of Tampa and the Pliocene beds of the Caloosahatchie River: Wagner Free Institute of Science of Philadelphia Transactions, v. 3, p 571-947.

Dall, W.H., 1902, Illustrations and descriptions of new, unfigured, or imperfectly known shells, chiefly American, in the U.S. National Museum: U.S. National Museum Proceedings, v. 24, p. 499-566.

Dall, W.H., 1909, Contributions to the Tertiary paleontology of the Pacific Coast, 1-The Miocene of Astoria and Coos Bay, Oregon: U.S. Geological Survey Professional Paper $59,278 \mathrm{p}$.

Dall, W.H., 1910, Notes on California shells. Nautilus, v. 24, p. 95-96. 
Dall, W.H., 1917, Summary of the mollusks of the family Alectrionidae of the west coast of America: U.S. National Museum Proceedings, v. 51, p. 575-579.

Dall, W.H., 1920, Annotated list of the recent Brachiopoda in the collection of the United States National Museum, with descriptions of thirty-three new forms: U.S. National Museum Proceedings, v. 57, p. 261-377.

Dall, W.H., and Pilsbry, H.A., 1891, On some recent Japanese Brachiopoda, with a description of a species believed to be new: Academy of Natural Sciences of Philadelphia, Proceedings, series 3, v. 43, p. 165-171.

Dana, J.D., 1852-1853, Crustacea, in United States Exploring expedition; During the years, 1838, 1839, 1840, 1841, 1841, under the command of Charles Wilkes, U.S.N: Philadelphia, v. 13 , no. 1, p. 1-1685 [1852], v. 13, no. 2, p. 1-1593 [1853].

Darwin, C., 1854, A monograph of the subclass Cirripedia with figures of all the species-The Balanidae (or sessile Cirripedea); the Verrucidae, etc., etc., etc: London, Ray Society, $684 \mathrm{p}$.

David, L.R., 1943, Miocene fishes of southern California: Geological Society of America Special Paper, v. 43, 193 p.

David, L.R., 1956, Tertiary anacanthin fishes from California and the Pacific Northwest-Their paleoecological significance: Paleontology Journal, v. 30, p. 568-607.

Deméré, T.A., 1983, The Neogene San Diego basin—A review of the marine Pliocene San Diego Formation, in Larue, D.K., and Steel, R.J., eds., Cenozoic marine sedimentation, Pacific margin U.S.A: Society of Economic Paleontologists and Mineralogists, p. 187-195.

Deméré, T.A., 1994a, The family Odobenidae-A phylogenetic analysis of fossil and living taxa: San Diego Society of Natural History Proceedings, v. 29, p. 99-123.

Deméré, T.A., 1994b, Two new species of fossil walruses (Pinnipedia: Odobenidae) from the upper Pliocene San Diego Formation, California: San Diego Society of Natural History Proceedings, v. 29, p. 77-98.

Deméré, T.A., and Berta, A., 2001, A reevaluation of Proneotherium repenningi from the Miocene Astoria Formation of Oregon and its position as a basal odobenid (Pinnipedia: Mammalia): Vertebrate Paleontology Journal, v. 21, p. 279-310.

Deméré, T.A., Berta, A., and Adam, P.J., 2003, Pinnipedimorph evolutionary biogeography: American Museum of Natural History Bulletin, v. 279, p. 32-76.
Denison, R.E., Koepnick, R.B., Fletcher, A., Howell, M.W., and Calloway, W.S., 1994, Criteria for the retention of original seawater ${ }^{87} \mathrm{Sr} /{ }^{86} \mathrm{Sr}$ in ancient shelf limestones: Chemical Geology, v. 112, p. 131-143.

Deshayes, G.P., 1839, Nouvelles espéces de mollusques, provenant des cotés de la Californie, du Méxique, du Kamtschatka et de la Nouvelle-Zélande: Révue zoologique, par la Société Cuvierienne, v. 2, p. 356-361.

Dillwyn, L.W., 1817, A descriptive catalogue of recent shells, arranged according to the Linnean method, with particular attention to the synonym: London, v. 1,580 p., v. 2, p. 581-1092.

Domning, D.P., 1978, Sirenian evolution in the North Pacific Ocean: University of California, Publications in Geological Sciences, v. 118, $176 \mathrm{p}$.

Domning, D.P., and Deméré, T.A., 1984, New material of Hydrodamalis cuestae (Mammalia: Dugongidae) from the Miocene and Pliocene of San Diego County, California: San Diego Society of Natural History Transactions, v. 20, p. 169-188.

Duméril, A.M.C., 1806, Zoologie analytique ou méthode naturelle de classification des animaux, rendue plus facile à l'aide de tableaux synoptiques: Paris, Allais, p. i-xxxii and $1-344$.

Durham, D.L., and Addicott, W.O., 1965, Pancho Rico Formation, Salinas Valley, California: U.S. Geological Survey Professional Paper no. 524-A, p. A1-A22.

Ebert, D.A., 2003, Sharks, Rays, and Chimaeras of California: Berkeley, University of California Press, 284 p.

Ebert, D.A., and Compagno, L.J.V., 2013, Sharks of the world-An annotated and illustrated catalogue of shark species known to date-Volume1, Cow, frilled, dogfish, saw, and angel sharks (Hexanchiformes, Squaliformes, Pristiophoriformes, and Squatiniformes): Food and Agriculture Organization of the United Nations, Fisheries and Aquaculture Department, FAO Species Catalogue for Fishery Purposes, v. 4, 535 p. [Also available at http://www.fao.org/ docrep/009/x9293e/x9293e00.htm.]

English, W.A., 1914, The Fernando Group near Newhall, California: University of California Publications, Department of Geology Bulletin, v. 8, p. 203-218.

Eschscholtz, J.F., von, 1829-1831, Zoologischer atlas, enthaltend abbildungen und beschreibungen neuer thierarten während des Flottcapitains von Kotzebue zweiter reise um die welt, auf der Russisch-Kaiserlichen Kriegsschlupp Predpriaetie in den Jahren 1823-1826 beobachtet: Berlin, G. Reimer, pts. 1-4 [for pt. 5 see Rathke, 1833]. 
Fierstine, H.L., Huddleston, R.W., and Takeuchi, G.T., 2012, Catalog of the Neogene bony fishes of California, a systematic inventory of all published accounts: Occasional Papers of the California Academy of Sciences, no. 159, 206 p.

Fitch, J.E. 1967, The marine fish fauna, based primarily on otoliths, of a lower Pleistocene deposit at San Pedro, California (LACMIP 332, San Pedro Sand): Los Angeles County Museum Contributions in Science, no. 82, 35 p.

Fitch, J.E., 1964, The fish fauna of the Playa Del Rey locality, a southern California marine Pleistocene deposit: Los Angeles County Museum Contributions in Science, no. 128, 23 p.

Fitch, J.E., 1968, Otoliths and other fish remains from the Timms Point Silt (early Pleistocene) at San Pedro, California: Los Angeles County Museum Contributions in Science, no. 146,29 p.

Fitch, J.E., 1970, Fish remains, mostly otoliths and teeth, from the Palos Verdes Sand (late Pleistocene) of California: Los Angeles County Museum Contributions in Science, no. 199, $41 \mathrm{p}$.

Fitch, J.E., and Lavenberg, R.J., 1971, California marine food and game fishes: University of California Press, Berkeley, $179 \mathrm{p}$.

Fitch, J.E., and Lavenberg, R.J., 1975, Tidepool and nearshore fishes of California: University of California Press, Berkeley, $156 \mathrm{p}$.

Fitch, J.E., and Reimer, R.D., 1967, Otoliths and other fish remains from a Long Beach, California, Pliocene Deposit: Bulletin of the Southern California Academy of Sciences, v. 66, no. 2, p. 77-91.

Fleck, R.J., Hagstrum, J.T., Calvert, A.T., Evarts, R.C., and Conrey, R.M., 2014, ${ }^{40} \mathrm{Ar} /{ }^{39} \mathrm{Ar}$ geochronology, paleomagnetism, and evolution of the Boring volcanic field, Oregon and Washington, USA: Geosphere, v. 10, p. 1283-1314, https:// doi.org/10.1130/GES00985.1.

Fleck, R.J., Sutter, J.F., and Elliot, D.H., 1977, Interpretation of discordant ${ }^{40} \mathrm{Ar} /{ }^{39} \mathrm{Ar}$ age-spectra of Mesozoic tholeiites from Antarctica: Geochimica et Cosmochimica Acta, v. 41, p. 15-32.

Fleming, J., 1822, The philosophy of zoology or a general view of the structure, functions and classification of animals, vol. 2: Constable \& Co., Edinburg, Hurst \& Co, London, $618 \mathrm{p}$.

Fleming, J., 1828, A history of British animals, exhibiting the descriptive characters and systematical arrangement of the genera and species of quadrupeds, birds, reptiles, fishes, Mollusca, and Radiata of the United Kingdom; including the indigenous, extirpated, and extinct kinds, together with periodical and occasional visitants: Edinburgh, Bell \& Bradfute \& London (Duncan), p. i-xxiii and 1-565.
Flower, W.F., 1869, Description of the Skeleton of Inia geoffrensis and of the skull of Pontoporia blainvillii, with remarks on the systematic position of these Animals in the order Cetacea: Zoological Society Transactions, London, v. 6, p. 87-116.

Flower, W.H., 1864, Notes on the skeletons of whales in the principle museums of Holland and Belgium, with description of two species apparently new to science: Proceedings of the Zoological Society of London for 1864, p. 384-420.

Forbes, E., 1852, On the marine Mollusca discovered during the voyage of the Herald and Pandora, by Capt. Kellett, R.N., and Lieut. Wood, R.N.: Zoological Society of London, for 1850 , p. 270-274.

Fossilworks, 2011, Calyptraea (Trochita) floridana Olsson and Petit 1964 (slipper shell): Fossilworks paleobiology data portal, accessed December 2011 at http:/fossilworks.org/ bridge.pl?taxon_no $=158722$ \&action $=$ taxonInfo.

Fossilworks, 2012, Takaradayskaya suite-Takaraday Railway Station, Kholmsk District, Sakhalin (Eocene of Russian Federation): Fossilworks paleobiology data portal, accessed July 2012 at http://fossilworks.org/bridge.pl?taxon_ no $=167913 \&$ max_interval $=$ Eocene $\&$ country $=$ Russian $\% 20$ Federation\&is_real_user $=1 \&$ basic $=$ yes \& type $=$ view \&action $=$ collectionSearch.

Foster, N.R., 1991, Intertidal bivalves - A guide to the common marine bivalves of Alaska: Fairbanks, University of Alaska Press, 152 p.

Gabb, W.M., 1869, Tertiary invertebrate fossils, in Gabb, W.M., Paleontology, vol. 2-Cretaceous and Tertiary fossils: California Geological Survey, p. 39-63.

Gaffney, P.M., Rupnow, J., and Domeier, M.L., 2007, Genetic similarity of disjunct populations of the giant sea bass Stereolepis gigas: Journal of Fish Biology, v. 70, p. 111-124.

Galloway, A.J., 1977, Geology of the Point Reyes Peninsula, Marin County, California: California Division of Mines and Geology Bulletin, v. 202, 72 p.

Gill, T.N., 1862, Analytical synopsis of the order Squali and revision of the nomenclature of the genera: Annals of the Lyceum of Natural History of New York, v. 7, p. 367-408. [Also available at https://www.biodiversitylibrary.org/bibliography/15987\#/summary.]

Gill, T.N., 1865, Note on the family of myliobatoids, and on a new species of Aetobatis: Annals of the Lyceum of Natural History of New York, v. 8, p.135-138. [Also available at https:/www.biodiversitylibrary.org/bibliography/15987\#/ summary.] 
Gill, T.N., 1884, On the Anacanthini fishes: Proceedings of the Academy of Natural Sciences of Philadelphia, v. 36, p. 167-183. [Also available at https://www.biodiversitylibrary. org/bibliography/6885\#/summary.]

Girard, C.F., 1858, Fishes, in General report upon zoology of the several Pacific railroad routes, 1857, in Reports of explorations and surveys, to ascertain the most practicable and economical route for a railroad from the Mississippi River to the Pacific Ocean: Washington, D.C., Beverley Tucker, $400 \mathrm{p}$.

Glen, W., 1959, Pliocene and lower Pleistocene of the western part of the San Francisco Peninsula: University of California Publications in Geological Sciences, v. 36, p. 147-198.

Gmelin, J.F., 1791, Caroli a Linné—Systema naturae per regna tria naturae, secundum classes, ordines, genera, species, cum characteribus, differentiis, synonymis, locis: Lipsiae, Georg. Emanuel, Beer Vermes, v. 1, pt. 6, p. 3021-3910.

Goodrich, E.S., 1909, The Vertebrata Craniata (Cyclostoms and Fishes), in Lankester, E.R., ed., Treatise on Zoology, vol. IX: London, E.R. Lankester, Adam Black, and Charles Black, 518 p.

Gorjansky, V.Y., and Popov, L.E., 1985, The morphology, systematic position, and origin of inarticulate brachiopods with carbonate shells: Paleontologicheskii Zhurnal, v. 3, p. 3-13.

Gould, A.A., 1850, [On the shells collected by the United States Exploring Expedition under the command of Charles Wilkes]: Boston Society of Natural History Proceedings, v. 3, p. 343-348.

Grant, U.S., IV, and Gale, H.R., 1931, Catalogue of the marine Pliocene and Pleistocene Mollusca of California: San Diego Society of Natural History Memoir, v. 1, 1036 p.

Grant, W.S., and Bowen, B.W., 1998, Shallow population histories in deep evolutionary lineages of marine fishesInsights from sardines and anchovies and lessons for conservation: Heredity Journal, v. 89, p. 415-426.

Gray, J.E., 1821, On the natural arrangement of vertebrate animals: The London Medical Repository Monthly Journal and Review, v. 15, p. 296-310.

Gray, J.E., 1824, Shells, in A supplement to the appendix of Captain Perry's voyage for the discovery of a north-west passage, in the years 1819-20-Containing an account of the subjects of natural history: London, Murray, p. ccxiccxlvi.

Gray, J.E., 1840, Synopsis of the contents of the British Museum, 42nd ed.: London, 370 p.

Gray, J.E., 1851, List of the specimens of fish in the collection of the British Museum-Part I, Chondropterygii: British Museum (Natural History), London, 160 p.
Gray, J.E., 1864, On the Cetacea which have been observed in the seas surrounding the British Isles: Zoological Society of London Proceedings, 1864, p. 195-248.

Graymer, R.W., Sarna-Wojcicki, A.M., Walker, J.P., McLaughlin, R.J., and Fleck, R.J., 2002, Controls on timing and amount of right-lateral offset on the East Bay fault system, San Francisco Bay region, California: Geological Society of America Bulletin, v. 114, no. 12, p. 1471-1479, https:// doi.org/10.1130/0016-7606(2002)114<1471:COTAAO >2.0 .CO;2.

Greenwood, P.H., Rosen, D.E., Weitzman, S.H. and Myers, G.S., 1966, Phyletic studies of teleostean fishes, with a provisional classification of living forms: American Museum of Natural History Bulletin, v. 131, p. 339-456.

Groves, L.T., 1991, Paleontology and biostratigraphy of the Plio-Pleistocene lower Saugus Formation, Santa Susana Mountain, southern California: Northridge, University of California, Master of Science thesis, 383 p.

Guilding, L., 1834, Observations on Naticina and Dentalium, two genera of molluscous animals: Linnean Society of London Transactions, v. 17, p. 29-35.

Gunnerus, J.E., 1765, Brugden (Squalus maximus), Beskrvenen ved J.E. Gunnerus: Det Trondhiemske Selskabs Skrifter, v. 3, p. 33-49.

Hernández, S., Vögler, R., Bustamante, C., and Lamilla, J., 2010, Review of the occurrence and distribution of the basking shark (Cetorhinus maximus) in Chilean waters: Marine Biodiversity Records, v. 3, e67, https://doi. org/10.1017/S1755267210000540.

Hertlein, L.G., 1925, Pectens from the Tertiary of Lower California: California Academy of Sciences Proceedings, series 4, v. 14, 35 p.

Hertlein, L.G., 1928, Preliminary report on the paleontology of the Channel Islands, California: Paleontology Journal, v. 2, p. 142-157.

Hertlein, L.G., and Grant, U.S., IV, 1944, The Cenozoic Brachiopoda of western North America: University of California, Publications in Mathematics and Physical Sciences, v. 3, $236 \mathrm{p}$.

Hickman, C.J.S., 1969, The Oligocene marine molluscan fauna of the Eugene Formation in Oregon: Oregon University Museum of Natural History Bulletin, no. 16, 112 p.

Hinds, R.B., 1844 [1845], The zoology of the voyage of H.M.S. Sulphur, under the command of Capt. Sir Edward Belcher R.N., C.B., F.R.G.S., etc., during 1836-1842Mollusca: London, Smith, Elder \& Co., v. 1, pl. 1-24 (July 1844); v. 2, pl. 25-48 (October, 1844); v. 3, pl. 49-72 (January 1845$)$. 
Hobson, E.S., 2006, Evolution, in Allen, L.G., Pondella, D.J., and Morn, M.H., eds., The Ecology of marine fishes-California and adjacent waters: University of California Press, Berkeley, p. 55-80.

Hochberg, F.G., 1996, The Brachiopoda17, in Blake, J.A., Scott, P.A., and Lissner, A., eds., Taxonomic atlas of the benthic fauna of the Santa Maria Basin and the western Santa Barbara Channel, Miscellaneous taxa: Santa Barbara Museum of Natural History Memoir, v. 14, p. 1-471.

Holland, P.J., and Allen, J.R., 1998, Description and interpretation of the Miocene-Pliocene Wilson Grove Formation, Steinbeck Ranch, Sonoma County, California: Geological Society of America Abstracts with Programs, v. 30, no. 7, p. 339.

Hosford Scheirer, A., and Magoon, L.B., 2007, Age, distribution, and stratigraphic relationship of rock units in the San Joaquin Basin province, California, in Hosford Scheirer, A., ed., Petroleum systems and geologic assessment of oil and gas in the San Joaquin Basin province: U.S. Geological Survey Professional Paper 1713, chap. 5, 107 p. [Also available at https://pubs.usgs.gov/pp/pp1713/.]

House, P.H., Clark, B.L.F., and Allen, L.G., 2016, The return of the king of the kelp forest-Distribution, abundance, and biomass of giant sea bass (Stereolepis gigas) off Santa Catalina Island, California, 2014-2015: Bulletin of the Southern California Academy of Sciences, v. 115, no. 1, p. 1-14.

Howard, H., 1929, The avifauna of Emeryville shellmound: University of California Publications in Zoology, v. 32, p. 301-394.

Howard, H., 1966, A possible ancestor of the Lucas auk (Family: Mancallidae) from the Tertiary of Orange County, California: Los Angeles County Museum Contributions in Science, no. 101, 8 p.

Howard, H., 1971, Pliocene avian remains from Baja California: Los Angeles County Museum Contributions to Science, no., 217, 17 p.

Howard, H., 1976, A new species of flightless auk from the Miocene of California (Alcidae: Mancallinae), in Olson, S.L., ed., Collected papers in avian paleontology honoring the 90th birthday of Alexander Wetmore: Smithsonian Contributions to Paleobiology, no. 27, p.141-146.

Howard, H., 1978, Late Miocene marine birds from Orange County, California: Natural History Museum of Los Angeles County Contributions to Science, no. 290, 26 p.

Howard, H., 1981, A new species of murre, genus Uria, from the late Miocene of California: Southern California Academy of Sciences Bulletin, v. 80, 12 p.
Howard, H., 1982, Fossil birds from the Tertiary marine beds at Oceanside, San Diego County, California, with descriptions of two new species of the genera Uria and Cepphus (Aves: Alcidae): Natural History Museum of Los Angeles County Contributions to Science, no. 341, 15 p.

Howarth, R.J., and McArthur, J.M., 1997, Statistics for strontium isotope stratigraphy, a robust LOWESS fit to the marine Sr-isotope curve for 0 to $206 \mathrm{Ma}$, with look-up table for derivation of numeric age: Journal of Geology, v. 105, p. $441-456$.

Hubbs, C.L., 1929, The genetic relationships and nomenclature of the California sardine: California Academy of Sciences Proceedings, series 4, v. 18, p. 261-265.

Huxley, T.H., 1867, On the classification of birds and on the taxonomic value of the modifications of certain of the cranial bones observable in the class: Zoological Society of London Proceedings, for 1867, p. 415-472.

Huxley, T.H., 1880, On the application of the laws of evolution to the arrangement of the Vertebrata, and more particularly of the Mammalia: Zoological Society of London Proceedings for 1880, p. 649-662.

Hyzny, M., Vega, F.J., and Coutiño, M.A., 2013, Ghost shrimp (Decapoda: Axilldae: Callianassidae) of the Maastrichtian (Late Cretaceous) Ocozocoautla Formation, Chiapas (Mexico): Boletín de la Sociedad Geológica Mexicana, v. 65 , p. 255-264.

Illiger, C., 1811, Prodromus systematis Mammalium et Avium: Berlin, Sumptibus C. Salfield, 236 p.

International Commission on Stratigraphy, 2012, International Chronostratigraphic Chart: International Commission on Stratigraphy, accessed July 2012, at http://www.stratigraphy.org.

Iredale, T., 1916, On some new and old molluscan generic names: Malacological Society of London Proceedings, v. 12, p. 27-37.

Iredale, T., 1922, Book notes: Malacological Society of London Proceedings, v. 15, p. 78-92.

Jaanusson, V.J., 1971, Evolution of the brachiopod hinge: Smithsonian Contributions to Paleobiology, v. 3, p. 33-46.

Jones, C.E., Jenkyns, H.C., Coe, A.L., and Hesselbo, S.P., 1994, Strontium isotopic variations in Jurassic and Cretaceous seawater: Geochimica Cosmochimica Acta, v. 58, p. 3061-3074.

Jordan, D.S., 1924, Rare species of fishes from the coast of southern California: Copeia, no. 134, p. 81-82.

Jung, P., 1969, Miocene and Pliocene mollusks from Trinidad: American Paleontology Bulletin, v. 55, p. 289-657. 
Kafanov, A.I., and Ogasawara, K., 2003, Neogene and Paleogene Molluscan (Bivalvia) Cenozones of Sakhalin and Kurile Islands: Institute of Geoscience, University of Tsukuba, Science Reports, v. 24, p. 45-79.

Kato, M., 1996, The unique intertidal subterranean habitat and filtering system of a limpet-like brachiopod, Discinisca sparselineata: Canadian Journal of Zoology, v. 74, p. 1983-1988.

Kaup, J.J., 1873, Die Familie Triglidae nebst einigen Worten über die Classification: Archiv für Naturgeschichte, v. 39, pt. 1, p. 71-94.

Keen, A.M., 1971, Sea shells of tropical west AmericaMarine mollusks from Baja California to Peru, 2nd ed.: Stanford, California, Stanford University Press, 1064 p.

Kellogg, R., 1927, Fossil pinnipeds from California: Carnegie Institution of Washington Publication, no. 348, p. 27-37.

Kern, J.P., and Wicander, E.R., 1974, Origin of a bathymetrically displaced marine invertebrate fauna in the upper part of the Capistrano Formation (lower Pliocene), southern California: Paleontology Journal, v. 48, p. 495-505.

Kincade, T., 1957., Local races and clines in the marine gastropod Thais lamellosa, a population study: Seattle, The Calliostoma Co., $75 \mathrm{p}$.

Klein, E.F., 1885, Beiträge zur bildung des schädels der knochenfische, 2: Jahreshefte des Vereins für Vaterländische Naturkunde in Württemberg, v. 42, p. 205-300.

Kowalewski, M., and LaBarbera, M., 2004, Actualistic taphonomy: death, decay, and disintegration in contemporary settings: Palaios, v. 19, p. 423-427.

Kuiper, K.F., Deino, A., Hilgen, F.J., Krijgsman, W., Renne, P.R., and Wijbrans, J.R., 2008, Synchronizing rock clocks of earth history: Science, v. 320, p. 500-504.

Lamarck, J.B.P.A. de M. de., 1809, Philosophie zoologique: Paris, Dentu, v. 1, p. i-xxv and 1-428.

Lamarck, J.B.P.A. de M. de., 1815-1822, Histoire naturelle des animaux sans vertébres: Paris, Verdière, v. 1-7 [for the dates of issue of this work, see Sherborn, C.D., 1922 (in Sherborn 1922-1933), sect. 2, p. lxxvii, and Iredale, T., 1922, p. 85].

Latreille, P.A., 1802, Histoire naturelle generale dt particuliére des crustacés et des insects: Paris, F. Dufar, v. 3, 467 p.

Latrielle, P.A., 1829, Les Crustaces, les Arachnides, les Insectes, in Cuvier, G., Le regne animal distribue d'apres son organasion, pour servir de base a l'histoire naturelle des animaux et d'introduction a l'anatomie: Paris, Chez Déterville, Libraire, ed. 2, v. 4, 653 p.
Leach, W.E., 1814-1817, The zoological miscellany; being descriptions of new, or interesting animals: London, v. 1, 144 p. (1814); v. 2, 154 p. (1815); v. 3, 149 p. (1817).

Linnaeus, C., 1758, Systema naturae per regna tria naturae, secundum classis, ordines, genera, species cum characteribus, differntiis, synonymis, oocis: Stockholm, Laurentii Salvii, 824 p.

Loel, W., and Corey, W.H., 1932, The Vaqueros Formation, lower Miocene of California [part] 1, Paleontology: University of California Publications, Department of Geological Sciences Bulletin, v. 22, p. 31-410.

Long, D.J., 1992, Paleoecology of Eocene Antarctic sharks, in Kennett, J.P., and Warnke, D.A., eds., The Antarctic paleoenvironment-A perspective on global change: American Geophysical Union, Antarctic Research Series, v. 56, p. 131-139.

Long, D.J., 1993a, Late Miocene and early Pliocene fish assemblages from the north-central coast of Chile: Tertiary Research, v. 14, p. 117-126.

Long, D.J., 1993b, Preliminary list of the marine fishes and other vertebrate remains from the late Pleistocene Palos Verdes Sand Formation at Costa Mesa, Orange County, California: PaleoBios, v. 15, p. 9-13.

Long, D.J., 1994, Historical biogeography of sharks from the eastern north Pacific Ocean: University of California, Berkeley, Ph.D. dissertation, 371 p.

Love, M.S., Yoklavitch, M., and Thorsteinson, L., 2002, The rockfishes of the Northeast Pacific: University of California Press, Berkeley, $405 \mathrm{p}$.

Lowry, M.S., 2011, Photographic catalog of California marine fish otoliths: prey of California sea lions (Zalophus californianus): National Oceanic and Atmospheric Administration, National Marine Fisheries Service, Southwest Fisheries Science Center, Technical Memorandum NOAA-TM-NMFSSWFSC-483 no.483, 250 p.

Lucas, F.A., 1901, A flightless auk, Mancalla californiensis, from the Miocene of California: U.S. National Museum Proceedings, v. 24, p. 113-134.

MacNeil, F.S., 1967, Cenozoic Pectinids of Alaska, Iceland, and other northern regions: U.S. Geological Survey Professional Paper 553, 57 p. [Also available at https://pubs. er.usgs.gov/publication/pp553.]

Magallanes, I., Parham, J.F., Santos, G.-P., and Velez-Juarbe, J., 2018, A new tuskless walrus from the Miocene of Orange County, California, with comments on the diversity and taxonomy of odobenids: PeerJ, v. 6, e5708, https://dx.doi. org/10.7717\%2Fpeerj.5708. 
Martin, B., 1916, The Pliocene of middle and northern California: University of California Publications, Bulletin of the Department of Geology, v. 9, p. 215-259.

McArthur, J.M., Crame, J.A., and Thirlwall, M.F., 2000, Definition of Late Cretaceous stage boundaries in Antarctica using strontium isotope stratigraphy: Journal of Geology, v. 108, p. 623-640.

McArthur, J.M., Howarth, R.J., and Bailey, T.R., 2001, Strontium isotope stratigraphy; LOWESS version 3; best fit to the marine Sr-isotope curve for 0-509 Ma and accompanying look-up table for deriving numerical age: Geology Journal, v. 109 , p. $155-170$.

McIntyre, G.A., Brooks, C., Compston, W., and Turek, A., 1966, The statistical assessment of Rb-Sr isochrones: Geophysical Research Journal, v. 71, p. 5459-5468.

McLaughlin, R.J., Sarna-Wojcicki, A.M., Wagner, D.L., Fleck, R.J., Langenheim, V.E., Jachens, R.C., Clahan, K., and Allen, J.R., 2012, Evolution of the Rodgers Creek-Maacama right-lateral fault system and associated basins east of the northward-migrating Mendocino Triple Junction, northern California: Geosphere, v. 8, no. 2, p. 342-373, https://doi. org/10.1130/GES00682.1.

McLean, J.H., 1966, A new genus of Fissurellidae and a new name for a misunderstood species of west American Diodora: Los Angeles County Museum Contributions in Science, no. 100, 8 p.

McLean, J.H., 1970, On the authorship of part 5 of Eschscholtz's 'Zoologischer Atlas,' 1833 [1829-1831]: The Veliger, v. 13, no. 1, p. 112.

McLean, J.H., 1978, Marine shells of southern California, revised edition: Natural History Museum of Los Angeles County, Science Series 24, 104 p.

Miller, D.J., and Lea, R.N., 1972, Guide to the coastal marine fishes of California: Sacramento, California Department of Fish and Game, Fish Bulletin, no. 157, 235 p.

Mitchell, E.D., 1962, A walrus and a sea lion from the Pliocene Purisima Formation at Santa Cruz, California; with remarks on the type locality and geologic age of the sea lion Dusignathus santacruzensis Kellogg: Los Angeles County Museum Contributions in Science, no. 44, 24 p.

Mitchell, E.D., 1968, The Mio-Pliocene pinniped Imagotaria: Fisheries Research Board of Canada Journal, v. 25, p. 1843-1900.

Montgomery, D.R., 2000, Coevolution of the Pacific salmon and Pacific Rim topography: Geology v. 28, p. 1107-1110.
Moody, C.L., 1916, Fauna of the Fernando of Los Angeles: University of California Publications, Department of Geology Bulletin, v. 10, p. 39-62.

Moore, E.J., 1963 [1964], Miocene marine mollusks from the Astoria Formation in Oregon: U.S. Geological Survey Professional Paper 419, 109 p. [Also available at https://pubs. er.usgs.gov/publication/pp419.]

Moore, E.J., 1983, Tertiary marine pelecypods of California and Baja California - Nuculidae through Malleidae: U.S. Geological Survey Professional Paper 1228-A, p. A1A108. [Also available at https://pubs.er.usgs.gov/publication/pp1228A.]

Moore, E.J., 1984, Tertiary marine pelecypods of California and Baja California—Propeamussiidae and Pectinidae: U.S. Geological Survey Professional Paper 1228-B, p. B1-B112. [Also available at https://pubs.er.usgs.gov/publication/ pp1228B.]

Moore, E.J., 1987, Tertiary marine pelecypods of California and Baja California-Plicatulidae to Ostreidae: U.S. Geological Survey Professional Paper 1228-C, p. C1-C53. [Also available at https://pubs.er.usgs.gov/publication/ pp1228C.]

Moore, E.J., and Addicott, W.O., 1987, The Miocene Pillarian and Newportian (Molluscan) stages of Washington and Oregon and their usefulness in correlations from Alaska to California, chap. A in Yochelson, E.L., ed., Shorter contributions to Paleontology and Stratigraphy: U.S. Geological Survey Professional Paper 1664, p. A1-A13. [Also available at https://pubs.usgs.gov/bul/1664/report.pdf.]

Muir-Wood, H.M., 1955, A history of the classification of the Phylum Brachiopoda: London, British Museum, 124 p.

Müller, J., 1846, On the structure and characters of the Ganoidei, and on the natural classification of fishes: Scientific Memoirs, v. 4, p. 499-542 [translated from Uber den Bau und die Grenzen der Ganoiden und iuberdas naturliche system der Fische, by J.W. Griffith, M.D.].

Müller, J., and Henle, F.G.J., 1838, On the generic characters of cartilaginous fishes, with descriptions of new genera: Natural History Magazine, new ser., v. 2, p. 33-37, 88-91.

Myers, A.T., Havens, R.G., Connor, J.J., Conklin, N.M., and Rose, H.J., Jr., 1976, Glass reference standards for the trace-element analysis of geologic materials - Compilation of interlaboratory data: U.S. Geological Survey Professional Paper 1013, 29 p. [Also available at https://pubs.usgs.gov/ pp/1013/report.pdf.] 
Nations, J.D., 1975, The genus Cancer (Crustacea: Brachyura) - Systematics, biogeography and fossil record: Natural History Museum of Los Angeles County, Science Bulletin, no. 23,104 p.

Near, T.J., Dornburg, A., Eytan, R.I., Keck, B.P., Smith, W.L., Kuhn, K.L., Moore, J.A., Price, S.A., Burbrink, F.T., Friedman, M., and Wainwright, P.C., 2013, Phylogeny and tempo of diversification in the superradiation of spiny-rayed fishes: Proceedings of the National Academy of Sciences, v. 110, no. 31 , p. $12738-12743$.

Nomland, J.O., 1916, Fauna from the lower Pliocene at Jacalitos Creek and Waltham Canyon Fresno County California: University of California Publications, Department of Geology Bulletin, v. 9, p. 199-214.

Nomland, J.O., 1917, The Etchegoin Pliocene of middle California: University of California Publications, Department of Geology Bulletin, v. 10, p. 191-254.

Oken, L., 1817, V. Kl. Fische: Isis (Oken), v. 1, pt. 8, no. 148, p. 1779-782.

Olson, S.L., 1985, The fossil record of birds, in Farmer, D.S., and King, A., eds., Avian biology: Orlando, Fla., Academic Press, v. 8, p. 79-252.

Olson, S.L., and Rasmussen, P., 2001, Miocene and Pliocene birds from the Lee Creek Mine, North Carolina: Smithsonian Contributions to Paleobiology, v. 90, p. 233-365.

Olsson, A.A., and Petit, R.E., 1964, Some Neogene Mollusca from Florida and the Carolinas: American Paleontology Bulletin, v. 47, p. 509-575.

Pack, R.W., and English, W.A., 1914, Geology and oil prospects in Waltham, Priest, Bitterwater, and Peachtree valleys, California, with notes on coal: U.S. Geological Survey Bulletin 581-D, p. 119-160.

Palmer, T.S., 1895, The earliest name for Steller's sea cow and dugong: Science, v. 2, no. 40, p. 449-450.

Perry, F.A., 1993, Fossil invertebrates and geology of the marine cliffs at Capitola, California: Santa Cruz, Santa Cruz City Museum, 30 p.

Peterman, Z.E., Hedge, C.E., and Tourtelot, H.A., 1970, Isotopic composition of strontium in seawater throughout Phanerozoic time: Geochimica Cosmochimica Acta, v. 34, p. 105-120.

Petit, R.E., 2009, George Brettingham Sowerby, I, II, \& III-Their conchological publications and Molluscan taxa: Zootaxa, no. 2189, 218 p.
Pontoppidan, E., 1763, Den Danske atlas eller Konge-Riget Dannemark, med dets naturlige egenskaber, elementer, indbyggere, værter, dyr og andre affødninger, dets gamle tildragelser og nærværende omstændingheder i alle provintzer, stæder, kirker, slotte og herre-gaarde-Forestillet ved en udførlig lands-beskrivelse, saa og oplyst med dertil forfærdigede land-kort over enhver provintz, samt ziret med stædernes prospecter, grund-ridser, og andre merkværdige kaabber-stykker-Efter Søy-kongelig allernaadigst befalning-Tomus I: Kiøbenhavn, A.H. Godiche, 723 p.

Powell, C.L., II, 1998, The Purisima Formation and related rocks (upper Miocene-Pliocene), greater San Francisco Bay area, central California-Review of literature and USGS collections (now housed at the Museum of Paleontology, University of California, Berkeley): U.S. Geological Survey Open-File Report 98-594, 102 p., [Also available at https:// pubs.usgs.gov/of/1998/of98-594/of98-594_2a.pdf.]

Powell, C.L., II, Allen, J.R., and Holland, P.J., 2004, Invertebrate paleontology of the Wilson Grove Formation (late Miocene to late Pliocene), Sonoma and Marin Counties, California, with some observations on its stratigraphy, thickness, and structure: U.S. Geological Survey Open-File Report 2004-1017, 106 p. [Also available at https://pubs. usgs.gov/of/2004/1017/].

Powell, C.L., II, Fisk, L.H., Maloney, D.F., and Haasl, D.M., 2010, Biostratigraphy of the San Joaquin Formation in borrow-source area B-17, Kettleman Hills landfill, North Dome, Kettleman Hills, Kings County, California: U.S. Geological Survey Open-File Report 2010-1140, 29 p. [Also available at http://pubs.usgs.gov/of/2010/1140/].

Powell, C.L., II, McLaughlin, R.J., and Wan, E., 2006, Biostratigraphy and lithologic correlations of two Sonoma County Water Agency pilot wells with the type Wilson Grove Formation, Sonoma County, central California: U.S. Geological Survey Open-File Report 2006-1196, 37 p. [Also available at https://pubs.usgs.gov/of/2006/1196/].

Powell, C.L., II., 2007, Outcrops and mollusks of the "Margaritan" California provincial molluscan stage in the northern Salinas Valley, Monterey and San Benito Counties, central California: PaleoBios, v. 27, p. 86-125.

Prothero, D.R., Lau, J.N., and Armentrout, J.M., 2001, Magnetic stratigraphy of the upper Miocene (Wishkahan) Empire Formation, Coos County, Oregon, in Prothero, D.R., ed., Magnetic stratigraphy of the Pacific Coast Cenozoic: Pacific Section SEPM (Society of Sedimentary Geology), book 91, p. 284-292. 
Quinteiro, J., Vidal, R., and Rey-Mendez, M., 2000, Phylogeny and biogeographic history of hake (genus Merluccius) inferred from mitochondrial DNA control-region sequences: Marine Biology, v. 136, p. 163-174.

Rafinesque, C.S., 1810, Caratteri di alcuni nuovi generi e nuove specie di animali e piante della Sicilia - Con varie osservazioni sopra i medisimi: Palermo, Per le stampe di Sanfilippo, part 1 (p. i-iv and 3-69) and part 2 ([with slightly different title] p. ia-iva and 71-105), pls. 1-20, https://doi.org/10.5962/bhl.title.104418.

Rafinesque, C.S., 1815, Analyse de la nature or $t$ ableau de l'univers et des corps organizes: Palerme, Aux dépens de l'auteur, 223 p., https://doi.org/10.5962/bhl.title.106607.

Rathke, M.H., 1833, Zoologischer atlas, enthaltend Abbildungen und Beschreibungen neuer Thierarten, während des Flottcapitains von Kotzebue Zweiter Reise um die welt die Welt auf der Russisch-Kaiserlichen Kriegesschlupp Predpriaetië in den Jahren 1823-1826 beobachtet von Joh. Friedrich Eschscholtz 1829-1831-Fünf Heft: Berlin, G. Reimer, p. i-vii, 1-28, pls. 21-25 [Completion of the work started by Eschscholtz, 1829-1831].

Reeve, L., 1843-1878, Conchologia iconica or illustrations of the shells of molluscous animals: London, v. 1-20 [with supplement to Conus, continued by G.B. Sowerby II, beginning with the genus Pyramidella in v. 15 (October 1865)], https://doi.org/10.5962/bhl.title.8129.

Regan, C.T., 1910, The origin and evolution of the teleostean fishes of the order Heterosomata: Annals and Magazine of Natural History, series 8, v. 6, no. 35, p. 484-496.

Reinhart, P.W., 1937, Three new species of the pelecypod family Aricdae: Paleontology Journal, v. 11, p. 181-185.

Repenning, C.A., and Tedford, R.H., 1977, Otarioid seals of the Neogene: U.S. Geological Survey Professional Paper 992, 93 p. [Also available at https://pubs.er.usgs.gov/publication/pp992.]

Richardson, J., 1975, Loop development and the classification of terebratellacean brachiopods: Palaeontology, v. 18, p. 285-314.

Roldan, M.I., Garcia-Marin, J.L., Utter, F.M., and Pla, C., 1999, Genetic relationships among Merluccius species: Heredity, v. 83, p. $79-86$.

Roth, B., 1979, Late Cenozoic marine invertebrates from northwest California and southwest Oregon: University of California, Berkeley, Ph.D. dissertation, 792 p.

Sandoval-Castillo, J., Ramirez-Gonzalez, J., and Villavicencio-Garayzar, C., 2008, First record of basking shark (Cetorhinus maximus) in Mexico?: Marine Biodiversity Records, v. 1, e19, https://doi.org/10.1017/S1755267206001874.
Sankey, J., Biewer, J., Basuga, J., Palacios, F., Wagner, H., and Garber, D., 2016, The giant, spike-toothed salmon, Oncorhynchus rastrosus and the "Proto-Tuolumne River" (early Pliocene) of Central California: Paleobios, v. 33, p. $1-16$.

Sarna-Wojcicki, A.M., 1971, Correlation of late Cenozoic pyroclastic deposits in the central Coast Ranges of California: University of California, Berkeley, Ph.D. dissertation, $174 \mathrm{p}$.

Sarna-Wojcicki, A.M., 1976, Correlation of late Cenozoic tuffs in the central Coast Ranges of California by means of traceand minor-element chemistry: U.S. Geological Survey Professional Paper 972, $32 \mathrm{p}$.

Sarna-Wojcicki, A.M., 1992, Long-term displacement rates of the San Andreas fault system in northern California from the 6-Ma Roblar tuff, in G. Borchardt, S.E. Hirschfeld, J.J. Lienkaemper, P. McClellan, P.L. Williams, and I.G. Wong, eds., Second conference on earthquake hazards in the eastern San Francisco Bay area proceedings: California Division of Mines and Geology Special Publication, no. 113, p. 29-30.

Sarna-Wojcicki, A.M., 2000, Tephrochronology, in Noler, J.S., Sowers, J.M., and Lettis, W.R., eds., Quaternary geochronology - Methods and applications: American Geophysical Union Reference Shelf 4, p. 357-377.

Sarna-Wojcicki, A.M., Deino, A.L., Fleck, R.J., McLaughlin, R.J., Wagner, D., Wan, E., Wahl, D., Hillhouse, J.W., and Perkins, M., 2011, Age, composition, and areal distribution of the Pliocene Lawlor Tuff, and three younger Pliocene tuffs, California and Nevada: Geosphere, v. 7, p. 599-628.

Schremp, L.A., 1981, Archaeogastropoda from the Pliocene Imperial Formation of California: Paleontology Journal, v. 55, p. 1123-1136.

Schumann, D., 1991, Hydrodynamic influences in brachiopod shell morphology of Terebratalia transversa (Sowerby) from the San Juan Islands, USA, in MacKinnon, D.I., Lee, D.E., and Campbell, J.D., eds., Brachiopods through time: Rotterdam, Balkema, 2nd International Brachiopod Congress Proceedings, p. 265-272.

Sherborn, C.D., 1902-1933, Index animalium: London, C.J. Clay \& Sons, Cambridge University Press Warehouse, sections 1-2, 1098 p. [section 1 (1902) list generic and specific names, with references, from 1758-1800; section 2, parts 1-33 (1922-33), lists names from 1800-1850].

Smith G.R., 1992, Introgression in fishes-Significance for paleontology, cladistics, and evolutionary rates: Systematic Biology, v. 41, p. 41-57.

Smith, N.A., 2011, Taxonomic revision and phylogenetic analysis of the flightless Mancallinae (Aves, Pan-Alcidae): Zookeys, v. 91, $116 \mathrm{p}$. 
Smith, N.A., 2013a, A new species of auk (Charadriiformes, Pan-Alcidae) from the Miocene of Mexico: The Condor, v. 115, p. 77-83.

Smith, N.A., 2013b, The fossil record and phylogeny of the auklets (Pan-Alcidae, Aethiini): Journal of Systematic Palaeontology, v. 12, p. 217-236.

Smith, N.A., and Clarke, J.A., 2011, An alphataxonomic revision of extinct and extant razorbills (Aves, Alcidae)A combined morphometric and phylogenetic approach: Ornithological Monographs, v. 72, 61 p.

Sowerby, G.B., I, 1846, Descriptions of thirteen new species of brachiopods: Proceedings of the Zoological Society of London, v. 14, p. 91-95. [There were three George Brettingham Sowerby's that published between 1839 and 1921 and the attribution of this paper to the first of that name is a best guess based on mostly indirect evidence (see also Petit, 2009)].

Sowerby, G.B., II, 1842, Monograph of the genus Pecten, in G.B. Sowerby II, ed., Thesaurus conchyliorum; or monographs of genera of shells, v. 1, no. 2, p. 45-82, pls. 12-20, https://doi.org/10.5962/bhl.title.10596.

Squires, R.L., 1992, New morphologic and geographic data on the neritid gastropod Nerita (Theliostyla) triangulata Gabb, 1869 from the Eocene of the Pacific coast of North America: The Veliger, v. 35, p. 323-329.

Squires, R.L., 1993, A new subgenus of neritid gastropod from the Upper Cretaceous of Baja California, Mexico: Paleontology Journal, v. 67, p. 579-590.

Squires, R.L., and Goedert, J.L., 1996, A new species of Thalassonerita? (Gastropoda: Neritidae?) from a middle Eocene cold-seep carbonate in the Humptulip Formation, western Washington: The Veliger, v. 39, p. 270-272.

Squires, R.L., and Saul, L.R., 1993, A new species of Otostoma (Gastropoda: Neritidae) from near the Cretaceous/Tertiary boundary at Dip Creek, Lake Nacimiento, California: The Veliger, v. 36, p. 259-264.

Squires, R.L., and Saul, L.R., 2002, New information on Late Cretaceous, Paleocene, and Eocene neritid gastropods from the North American Pacific slope: The Veliger, v. 45, p. 177-192.

Stearley, R.F. 1992, Historical ecology of Salmoninae, with special reference to Oncorhynchus, in Mayden, R.L., ed., Systematics, historical ecology, and North American freshwater fishes: Stanford, Calif., Stanford University Press, p. $622-658$.

Storer, R.W., 1960, Evolution in the diving birds, in Bergman, G., Donner, K.O., and Haartman, L.V., eds., Proceedings of the Twelfth International Ornithological Congress: Helsinki, Tilgmannin Kirjapaino, p. 694-707.
Suckley, G., 1861, Notices of certain new species of North American Salmonidae. chiefly in the collection of the N.W. Boundary Commission, in charge of Archibald Campbell, Esq., Commissioner of the United States, collected by Doctor C. B. R. Kennerly, naturalist to the: Annals of the Lyceum of Natural History of New York, v. 7, art. 30, p. 306-313 [Also available at https://www.biodiversitylibrary. org/bibliography/15987\#/summary.]

Tedford, R.H., Albright, III, L.B., Barnosky, A.D., FerrusquiaVillafranca, I., Hunt, Jr., R.M., Storer, J.E., Swisher, III, C.C., Voorhies, M.R., Webb, S.D., and Whistler, D.P., 2004, 6. Mammalian biochronology of the Arikareean through Hemphillian interval (late Oligocene through early Pliocene Epochs), in Woodburne, M.O., ed., Late Cretaceous and Cenozoic Mammals of North America-Biostratigraphy and Geochronology: New York, Columbia University Press, p. 169-231, https://doi.org/10.7312/wood13040-008.

Thomson, J.A., 1926, A revision of the subfamilies of the Terebratulidae (Brachiopoda): Annals and Magazine of Natural History, series 9, v. 18, p. 523-530.

Thomson, J.A., 1927, Brachiopod morphology and genera (recent and Tertiary): New Zealand Board of Science and Art Manual, v. 7, 338 p.

Touring, R.M., 1959, Structure and stratigraphy of the La Honda and San Gregorio Quadrangles, San Mateo County, California: Stanford, Calif., Stanford University, Ph.D. dissertation, $228 \mathrm{p}$.

Travis, R.B., 1952, Geology of the Sebastopol Quadrangle, California: California Department of Natural Resources, Division of Mines Bulletin 162, 33 p.

True, F.W., 1905, Diagnosis of a new genus and species of fossil sea-lion from the Miocene of Oregon: Smithsonian Miscellaneous Collections, v. 48, p. 47-49.

Vadopaias, B., Pietsch, T.W., and Friedman, C.S., 2010, The proper name for the Geoduck-Resurrection of Panopea generosa Gould, 1850, from the synonymy of Panopea abrupta (Conrad, 1849) (Bivalvia: Myoida: Hiatellidae): Malacologia, v. 52, p. 189-173.

Valentine, J.W., 1958, Late Pleistocene megafauna of Cayucos, California, and its geographic significance: Paleontology Journal, v. 32, p. 687-696.

Valentine, J.W., 1980, Camalu-A Pleistocene terrace fauna from Baja California: Paleontology Journal, v. 54, p. 1310-1318.

Vega, F.J., Feldmann, R.M., and Villalobos-Hiriart, J.L., 1995, Additions to the crustacean (Decapoda) fauna from the Portrerillos Formation (Late Cretaceous) in northeastern Mexico: Carnegie Museum Annals, v. 64, p. 239-249. 
Veizer, J., 1989, Strontium isotopes in seawater through time: Annual Reviews Earth and Planetary Science, v. 17, p. 141-167.

Vendrasco, M.J., Eernisse, D.J., Fernandez, C.Z., and Powell, C.L., II, 2012, Polyplacophora from the San Diego Formation-A remarkable assemblage of fossil chitons from the Pliocene of southern California: Natural History Museum of Los Angeles County, Contributions in Science no. 520, p. 15-72. [Also available at https://nhm.org/site/sites/default/ files/pdf/contrib_science/CS520.15-72.pdf.]

Vermeij, G.J., Frey, M.A., and Landau, B.M., 2009, The gastropod genus Nerita in the Neogene of Tropical America: Cainozoic Research, v. 6, p. 61-70.

Vinas, J., Bremer, J.R.A., and Pla, C., 2010, Phylogeography and phylogeny of the epineritic cosmopolitan bonitos of the genus Sarda (Cuvier) - Inferred patterns of intra- and interoceanic connectivity derived from nuclear and mitochondrial DNA data: Biogeography Journal, v. 37, p. 557-570.

von den Driesch, A., 1976, A guide to the measurement of animal bones from archaeological sites: Peabody Museum Bulletin, v. 1, p. 103-129.

Waagen, W.H., 1882-1885, Salt Range fossils-Productus limestone fossils, Brachiopoda: Geological Survey of India Memoir, Palaeontologia Indica, series 13, v. 1, p. 329-770.

Wagner, D.L., Rice, S.R., Bezore, S.P., Randolph-Loar, C.E., Allen, J., and Witter, R.C., 2002, Geologic map of the Petaluma River 7.5' quadrangle, Marin and Sonoma Counties, California-A digital database: California Geological Survey. [Also available at ftp://ftp.consrv.ca.gov/pub/dmg/ rgmp/Prelim_geo_pdf/petaluma_river_layout_highres. pdfx].

Wagner, D.L., Saucedo, G.J., Clahan, K.B., Fleck, R.J., Langenheim, V.E., McLaughlin, R.J., Sarna-Wojcicki, A.M., Allen, J.R., and Deino, A.L., 2011, Geology, geochronology, and paleogeography of the southern Sonoma volcanic field and adjacent areas, northern San Francisco Bay region, California: Geosphere, v. 7, p. 658-683.

Warheit, K.I., 1992, A review of the fossil seabirds from the Tertiary of the north Pacific_-Plate tectonics, paleoceanography, and faunal change: Paleobiology, v. 18, p. 401-424.

Warheit, K.I., 2002, The seabird fossil record and the role of paleontology in understanding seabird community structure, in Schrieber, E.A., and Burger, J., eds., Biology of marine birds: Boca Raton, Fla., CRC Press, p. 17-55.

Welton, B.J., 1979, Late Cretaceous and Cenozoic Squalomorphii of the Northwest Pacific Ocean: University of California, Berkeley, Ph.D. Dissertation, 553 p.
Welton, B.J., 2013a, A new archaic basking shark (Lamniformes: Cetorhinidae) from the late Eocene of western Oregon, U.S.A., and description of the dentition, gill rakers and vertebrae of the recent basking shark Cetorhinus maximus (Gunnerus): New Mexico Museum of Natural History and Science Bulletin 58, 48 p.

Welton, B.J., 2013b, Cetorhinus cf. C. maximus (Gunnerus 1765) (Neoselachii: Cetorhinidae), a basking shark from the late Miocene Empire Formation, Coos Bay, Oregon: Southern California Academy of Sciences Bulletin, v. 112, p. 74-92.

Welton, B.J., 2015, The marine fish fauna of the middle Pleistocene Port Orford Formation and Elk River Beds, Cape Blanco, Oregon: New Mexico Museum of Natural History and Science Bulletin 66, 45 p.

Whitehead, P.J.P., 1985, FAO species catalogue-Volume 7, Clupeoid fishes of the world-An annotated and illustrated catalogue of the herrings, sardines, pilchards, sprats, anchovies, and wolf-herrings-Part 1, Chirocentridae, Clupeidae and Pristigasteridae: Food and Agriculture Organization of the United Nations, Fisheries and Aquaculture Department, FAO Fisheries Synopsis, v. 125, 303 p. [Also available at http://www.fao.org/docrep/009/ac482e/ac482e00.htm.]

Whitmore, F.C., and Barnes, L.G., 2008, The Herpetocetinae, a new subfamily of extinct baleen whales (Mammalia, Cetacea, Cetotheriidae), in Ray, C.E., Bohaska, D.J., Koretsky, I.A., Ward, L.W., and Barnes, L.G., eds., Geology and paleontology of the Lee Creek Mine, North Carolina, IV: Virginia Museum of Natural History Special Publication 14, p. 141-180.

Williams, A., Carlson, S.J., Brunton, C.H.C., Holmer, L.E., and Popov, L.E., 1996, A supra-ordinal classification of the Brachiopoda: Philosophical Transactions of the Royal Society of London, series B, v. 351, p. 1171-1193.

Woodring, W.P., 1938, Lower Pliocene mollusks and echinoids from the Los Angeles Basin, California, and their inferred environment: U.S. Geological Survey Professional Paper 190, 67 p. [Also available at https://pubs.er.usgs.gov/publication/pp190.]

Woodring, W.P., 1957, Geology and paleontology of the Canal Zone and adjoining pats of Panama-Geology and description of Tertiary mollusks (Gastropoda: Trochidae to Turritellidae): U.S. Geological Survey Professional Paper 306-A, 145 p. [Also available at https://pubs.er.usgs.gov/ publication/pp306A.]

Woodring, W.P., and Bramlette, M.N., 1950 [1951], Geology and paleontology of the Santa Maria District, California: U.S. Geological Survey Professional Paper 222, 185 p. [Also available at https://pubs.er.usgs.gov/publication/ pp222.] 
Woodring, W.P., Bramlette, M.N., and Kew, W.S.W., 1946, Geology and paleontology of the Palos Verdes Hills, California: U.S. Geological Survey Professional Paper 207, 145 p. [Also available at https://pubs.er.usgs.gov/ publication/pp207.]

Woodring, W.P., Bramlette, M.N., and Lohman, K.E., 1943, Stratigraphy and paleontology of Santa Maria District, California: American Association of Petroleum Geologists Bulletin, v. 27, p. 1335-1360.

Woodring, W.P., Stewart, R., and Richards, R.W., 1940, Geology of the Kettleman Hills oil field, CaliforniaStratigraphy, paleontology, and structure: U.S. Geological Survey Professional Paper 195, 170 p. [Also available at https://pubs.er.usgs.gov/publication/pp195.]

Woods, A.J.C., and Saul, L.R., 1986, New Neritidae from southwestern North America: Paleontology Journal, v. 60, p. 636-655.
Zeigler, C.V., Chan, G.L., and Barnes, L.G., 1997, A new Late Miocene balaenopterid whale (Cetacea: Mysticeti), Parabalaenoptera baulinensis, (new genus and species) from the Santa Cruz Mudstone, Point Reyes Peninsula, California: Proceedings of the California Academy of Sciences, v. 50, p. 115-138.

Zinsmeister, W.J., 1970, A late Pliocene macrofossil fauna of Newport Beach, Orange County, California: Bulletin of the southern California Academy of Sciences, v. 69, p. $121-125$.

Zullo, V.A., and Guruswami-Naidu, R.B., 1982, Late Miocene balanid Cirripedia from the basal Wilson Grove Beds ("Merced" Formation), Sonoma County, northern California: California Academy of Sciences Proceedings, v. 42, p. 525-535. 


\section{Appendix-Taxonomic Notes}

\author{
Institutional abbreviations - CAS, California Academy \\ of Sciences; NCSM, North Carolina Museum of Natural \\ Sciences; LACM, Natural History Museum of Los Angeles \\ County; SDNHM, San Diego Natural History Museum; \\ UCMP, University of California Museum of Paleontology; \\ USNM, National Museum of Natural History, Smithsonian \\ Institution.
}

\section{Invertebrates}

Taxa are arranged taxonomically following the Treatise on Invertebrate Paleontology for the higher classification of invertebrates and following Bouchet and others (2010) for the bivalve mollusks and Bouchet and Rocroi (2005) for the gastropods. Discussed below are only specimens that can be confidently identified, and (or) aid in age and environmental interpretation. Other specimens are found in collections but due to poor preservation are not identifiable, or in the instance of Bryozoa, are not identified because of lack of expertise.

\section{Brachiopods by Sandra J. Carlson}

\author{
Phylum Brachiopoda Duméril, 1806 \\ Subphylum Linguliformea Williams and others, 1996 \\ Class Lingulata Gorjansky and Popov, 1985 \\ Order Lingulida Waagen, 1885 [see Waagen, 1882-1885] \\ Superfamily Discinoidea Gray, 1840 \\ Family Discinidae Gray, 1840 \\ Genus Discinisca Dall, 1871 \\ Discinisca cf. D. cumingii (Broderip, 1833) \\ Plate 1, figure 1
}

Abundant ( $>25$ specimens), moderately well to poorly preserved inarticulated brachiopod dorsal valves, the best preserved of which are assigned to Discinisca $\mathrm{cf}$. D. cumingii, occur at CAS locality 54136 . They can reach large $(>20$ millimeters, $\mathrm{mm}$ ) size, and are gently conical and roughly circular to oval in outline with irregular, moderate concentric ribs around an eccentrically placed umbo. Faint to moderate radial ribs are visible mainly over the outer (older) regions of the dorsal valve surface, at some distance from the umbo. Nodes form in a vaguely reticulate pattern where the radial and concentric ribs cross. No ventral valves, which would retain the characteristic slit-like pedicle opening, were observed. Reported by Broderip (1835, p. 203) to range in the Holocene from Cabo San Lucas (Baja California Sur, Mexico) to Panama, and extending as far south as Chile along the Pacific coast of Central and South America, "attached to the lower side of stones in sandy mud at low water, and in some instances at a depth of from six to eight fathoms" (Cuming). Extant congeners (D. sparselineata; Kato, 1996) in Japan live in the middle intertidal zone "attached beneath boulders that were deeply buried in coarse sand," protected from many biotic and abiotic threats. Warm and very shallow water $(<60$ feet depth) habitat was likely for $D$. cumingii; lower depth range unknown. More details on the occurrence of this genus and species in California can be found in Hertlein and Grant (1944), as well as Adegoke (1969).

These brachiopods have chitinophosphatic valves and fossilize with a distinctive golden brown to black color and a lustrous sheen, preserving fine details of the exterior ornament; no color bands can be observed. The radial and concentric ornament together distinguish this species from others in the genus. Dorsal valves vary considerably in conical height and in location of the umbo, from central to marginal; ornament is also variable in appearance among individuals. Dorsal valve interiors are largely filled with well-cemented fine sandstone, making it impossible to see anatomical features on most valve interiors. Valve interiors were exposed in approximately six individuals, but unfortunately no adductor muscle scars were visible; no median septum was present either, clearly distinguishing these valves from West African Discina.

In fist-sized samples of sandstone from CAS locality 54135, Discinisca valves can be seen floating in the rock matrix, unoriented and dispersed from one another, which suggests that the dorsal valves were removed by physical (wave?) force from the ventral valves that remained attached by the pedicle to the underside of rocks, and were then deposited very rapidly. Specimens are rarely deformed, but may be chipped along the commissural margin.

Subphylum Rhynchonelliformea Williams and others, 1996 Class Rhynchonellata Williams and others, 1996

Order Terebratulida Waagen, 1883 [see Waagen, 1882-1885] Suborder Terebratulidina Waagen, 1883 [see Waagen, 1882-1885]

Family Cancellothyrididae Thomson, 1926

Genus Terebratulina d'Orbigny, 1847 Terebratulina cf. T. unguicula (Carpenter, 1864) Plate 1, figures $2,3,4$

Ten partial and single elongate valves with fine radial sculpture collected from CAS locality 54135 are identified as Terebratulina cf. T. unguicula, based on distinctive features of the dorsal cardinalia, but all are missing the short loops supporting the lophophore that characterize terebratulidines. Some of the fragments are too incomplete to warrant definitive identification, but can be clearly distinguished from Terebratalia by their smaller size, thinner valves, and very delicate radial ribs (costellae). Bloomfield Quarry specimens are similar in size to T. unguicula, but the specimen figured 
in plate 1 is wider than long, whereas T. unguicula is more often longer than wide, as is the case for several of the less complete, unfigured specimens. Several of the smaller valves $(5 \mathrm{~mm})$ are flatter and nearly equal in length and width, which is more similar to T. kiiensis Dall and Pilsbry, 1891. The full range of variability in valve proportions cannot be determined from the small sample size here.

Terebratulina unguicula is the more common Miocene species of Terebratulina from western North America and has a modern range from the Pribilof Islands in the Bering Sea, off Alaska, south to Cabo San Lucas, Baja California Sur, Mexico (Dall, 1920), from 10 to $850 \mathrm{~m}$ (Hochberg, 1996). Hertlein and Grant (1944) report it as a fossil from the Miocene of Oregon to the middle Pleistocene Lomita Marl (then considered late Pliocene) of southern California.

Suborder Terebratellidina Muir-Wood, 1955 Superfamily Laqueoidea Thomson, 1927 Family Terebrataliidae Richardson, 1975 Genus Terebratalia Beecher, 1893

Type species-Terebratalia transversa (Sowerby, 1846), by original designation by Beecher, 1893

This genus is highly variable in many external morphological features, in both extant and extinct forms (Schumann, 1991). Distinctions among named species are not clear in practice, and specimens can vary by "insensible gradations" from one species to another (Hertlein and Grant, 1944; p. 119). Valve shape varies from weakly to strongly biconvex, from longer than wide to wider than long, from unisulcate to rectimarginate to uniplicate, and from strongly ribbed to smooth, with concentric growth lines that range from faint to broad and rugose. Extant $T$. transversa attach to a hard substrate by a pedicle, do not move once they settle and metamorphose on that substrate, and live in gregarious clusters, which can cause crowding and disrupt the bilateral symmetry of the valves in unpredictable ways.

Terebratalia occidentalis (uniplicate, with dorsal fold) outnumbers T. transversa (unisulcate, with dorsal sulcus) by approximately 5 to 1 among Bloomfield Quarry specimens. Dorsal valves of Terebratalia outnumber ventral valves in these collections by roughly 4 to 1 . Ventral valves exhibit large to very large pedicle foramina and broad palintropes. Many of the valves, dorsal and ventral, preserve natural irregularities in shape due to crowding in life; many (particularly those from CAS locality 54135), but not all, also exhibit post-depositional crushing fractures and early diagenetic bending of shells, due to decay of the large amount of organic material contained within the fabric of the valves shortly after death. Terebratalia valves interlock in articulation in life (Jaanusson, 1971; Carlson, 1989) but are not uncommonly separated after death; the relatively large number of articulated specimens indicates that these individuals were buried shortly after death and, if transported, were not moved far from their life position and were probably moved while the animal was still alive, causing their death, or immediately after death. A few sedimentary blocks from Bloomfield Quarry contain abundant brachiopods, as a coquina of disarticulated valves; they most likely were transported at least some distance before deposition. Most valves, originally low magnesium calcite, from CAS localities 54135 and 54136 are medium to dark gray in color, similar to the fine sandstone matrix in which they are preserved, but some from the basal conglomerate at CAS locality 54135 are a creamy white color and hardly look fossilized. Brachiopods are far less commonly preserved in Tertiary sedimentary rocks than are mollusks; the relative abundance of brachiopods in Bloomfield Quarry indicates that they were deposited close to their hard-substrate habitat in life. Terebratalia ranges stratigraphically from Eocene to Holocene and occurs today along western North America and Japan, from high intertidal to generally less than $200 \mathrm{~m}$ depth.

\section{Terebratalia $\mathrm{cf}$. T. transversa (Sowerby, 1846) Plate 1, figures 8,10}

One articulated specimen, abundant $(>25)$ single and partial valves are in collections from CAS locality 54135, and an additional three articulated specimens, five single valves and four internal molds (steinkerns) are present from CAS locality 54136. Many specimens are deformed, either before and/or after deposition, but all are easily recognized as Terebratalia and a small percentage ( $<20$ percent) are identifiable as Terebratalia cf. T. transversa. Terebratalia transversa is distinguished from T. occidentalis by the presence of a weak dorsal sulcus and ventral fold (Hertlein and Grant, 1944). Although this species is locally common today in patches along the west coast of North America, it is not the most abundant morphology among Bloomfield Quarry Terebratalia.

Terebratalia transversa [syn. T. caurina Gould, 1850; T. transversa v. rubescens Dall, 1910; T. hemphilli Dall, 1902; fide Hochberg, 1996] has a fossil record from the Miocene and Pleistocene from Alaska to California (Hertlein and Grant, 1944). It is reported living from Kodiak Island, Gulf of Alaska south to off Ensenada, Baja California, Mexico (Burch, 1942), from the intertidal zone to $1,800 \mathrm{~m}$ in the south (Hochberg, 1996).

\section{Terebratalia cf. T. occidentalis Dall, 1891 Plate 1, figures 5, 6, 7, 9}

At least 10 articulated specimens and abundant $(>100)$ single and partial valves from CAS localities 54135 and 54136 resemble (cf.) T. occidentalis obsoleta as illustrated by Hertlein and Grant (1944, plate 12, figs. 9-11), most closely the variant named as a distinct species, $T$. arnoldi, by Hertlein and Grant (1944, p. 119). Terebratalia occidentalis is characterized primarily by a dorsal fold and ventral sulcus, which are commonly weakly developed, but frequently rather sharply demarcated from the rest of the valve. Valve length and width are often nearly equal, but individuals can be considerably wider than long; biconvexity varies but is often relatively strong. Radial ribs are commonly present and broad, but weakly developed, occasionally bifurcate, and occasionally absent entirely; they may be present only on the posterior region of the shell or only the anterior region. More typical $T$. occidentalis obsoleta has a nearly smooth shell with strongly developed fold and sulcus, but the abundant 
specimens collected at Bloomfield Quarry show considerable variation in the development of the fold and sulcus, of radial ribs, and in overall shell shape.

Terebratalia occidentalis [syn. Waldheimia kennedyi Dall, 1874; T. occidentalis obsoleta Dall, 1891; T. arnoldi Hertlein and Grant, 1944; Miogryphus wiletti Hertlein and Grant, 1944; fide Hochberg, 1996] has been reported in the Miocene from Clallum Bay, Clallum County, Washington, south to Los Angeles County, southern California, from the Pliocene from Los Angeles County, southern California, and is reported living from Monterey, Monterey County, California, south to Cabo San Lucas, Baja California Sur, Mexico, and out to Isla Cedros, Baja California Sur, Mexico, at water depths to 50 to $250 \mathrm{~m}$ (Hochberg, 1996). Hertlein and Grant (1944) report T. occidentalis obsoleta from the late Miocene to Pliocene from Oregon to southern California and $T$. occidentalis from the Oligocene of Washington to the Pliocene of southern California with many occurrences in between. Together these occurrences indicate an Oligocene to Pliocene age range for $T$. occidentalis.

\section{Mollusks by Charles L. Powell II}

\author{
Phylum Mollusca Linnaeus, 1758 \\ Class Bivalvia Linnaeus, 1758 (Taxonomy follows Bouchet \\ and others, 2010) \\ Family Nuculidae Gray, 1824 \\ Yoldia sp. indeterminate \\ Plate 2, figures 1, 4, 5, 6
}

Two internal molds from CAS locality 54135 resemble the genus Yoldia, but the outline is poorly defined and the shell lacks detail so further identification is not possible.

Family Mytilinae Rafinesque, 1815

Crenomytilus cf. C. coalingensis (Arnold, 1909 [1910]) Plate 2, figure 16

One moderately well preserved valve from CAS locality 54135 is referred to Crenomytilus $\mathrm{cf}$. C. coalingensis based on size and shape. The characteristic fine transverse rows of pustules on the exterior of the anterior ventral end are not preserved, making the identification provisional. Crenomytilus coalingensis is reported in Moore (1983) from the Castaic, Etchegoin, Fernando, Merced, Niguel, Pancho Rico, San Joaquin, and Towsley Formations, indicating an age range from the "Jacalitos" to "San Joaquin" CPMS. In addition, Powell (2007) provisionally reported it from the late Miocene "Margaritan" CPMS.

\section{Mytilus sp. indeterminate}

Several large shell fragments resembling the genus Mytilus are present in large conglomeratic clasts from CAS locality 54134, and fragments of indeterminate Mytilus shells are present from CAS locality 54135. In addition, numerous partial specimens of an indeterminate Mytilus are also present.
Unfortunately, none are well enough preserved to identify beyond Mytilus sp.

\section{Modiolus sp. indeterminate}

One internal mold fragment and one articulated internal mold missing its umbonal end from CAS locality 54136 are assigned to the genus Modiolus based on their size and shape. Unfortunately, they are not well enough preserved to identify to species. The genus Modiolus is widespread in the eastern Pacific Ocean and not ecologically or chronostratigraphically significant here.

\section{Indeterminate Mytilidae}

A single fragment of a valve from CAS locality 54136 is assigned to an indeterminate Mytilidae, based on its sculpture and internal pearly luster similar to that seen in Geukensia demissum (Dillwyn, 1817). Because G. demissum was introduced to the eastern Pacific Ocean from the Atlantic Ocean during the past century, the Bloomfield Quarry specimen cannot be attributed to that species and remains unidentified.

\section{Family Arcidae Lamarck, 1809 Anadara sp. indeterminate}

Several shell fragments from CAS locality 54135 resemble the genus Anadara and are identified as indeterminate species within that genus.

\section{Arca cf. A. santamariensis Reinhart, 1937} Plate 2, figures 2, 3

Four incomplete specimens and three internal molds from CAS locality 54135 are referred to Arca santamariensis based on their sculpture and irregular shell outline. The best-preserved specimen is easily identified as this species but is much larger than previously reported for this species, in excess of 50 $\mathrm{mm}$ and still appears slightly incomplete, whereas the type is only $26 \mathrm{~mm}$ long. These specimens are therefore provisionally identified. Arca santamariensis has previously been reported from the Niguel Formation (originally referred to Capistrano Formation, fide Groves, 1991) in Orange County (Vedder in Kern and Wicander, 1974) and Cebada Member of the Careaga Sandstone in the Santa Margarita District (Woodring in Woodring and Bramlette, 1950 [1951]), both of Pliocene age. Therefore, its occurrence in the lower Wilson Grove Formation at Bloomfield Quarry extends its stratigraphic range to the late Miocene.

Family Anomiidae Rafinesque, 1815

Pododesmus cf. P. macrochisma (Deshayes, 1839)

Plate 2, figures 7, 15

Three incomplete valves and two fragments from CAS locality 54136 are provisionally (cf.) assigned to Pododesmus macrochisma (Deshayes, 1839) based on their shape and sculpture. Pododesmus macrochisma has a modern range from Wainright, Chukchi Sea, Alaska, south to Bahia Magdalena, Baja California Sur, and near Guaymas, Sonora, Mexico, from 
the intertidal zone to $90 \mathrm{~m}$ attached to a hard substrate (Coan and others, 2000). Moore (1987) reports P. macrochisma as occurring in formation from the "Margaritan" CPMS to late Pleistocene.

\section{Anomia peruviana d'Orbigny, 1846}

In addition, a single specimen from CAS locality 54135 resembles Anomia peruviana and is assigned to that species. Anomia peruviana as a modern occurrence from Monterey, central California south through the Gulf of California, Mexico, to Paita, Peru, at intertidal water depths to $120 \mathrm{~m}$ (Coan and others, 2000). This species has been reported from the late Miocene (C. Powell, oral commun. in Moore, 1987) to Holocene (Coan and others, 2000). The previous Miocene occurrence is from proto-Gulf California deposits in southcentral California. The occurrence here is the first from the Miocene of coastal California.

\section{Family Pectininae Rafinesque, 1815}

At least three species of Chlamys are present from CAS locality 54135 . These three taxa are distinguished by the structure and number of radial ribs, shell microsculpture, and the auricles. In addition, indeterminate Patinopecten and Swiftopecten parmeleei occur at the Bloomfield Quarry.

\section{Chlamys hodgei (Hertlein, 1925) Plate 2, figure 11}

The first, Chlamys hodgei (Hertlein, 1925), is best represented at Bloomfield Quarry by a small right valve, higher than long and equilateral with about 17 major radial ribs and an apical angle of about $95^{\circ}$. These features and the riblets on either side of the major ribs, fine sharp imbricated spines, and very finely pitted surface serve to identify this species. Chlamys hodgei occurs in the "Margaritan" and "Jacalitos" CPMS in California and Oregon indicating a middle late to late Miocene age range for this species (Addicott, 1981).

\section{Chlamys n. sp., aff. C. egregius (Nomland, 1917) Plate 2, figure 12}

Chlamys n. sp., aff. C. egregius, the second species, is also small, with about 25 wide radial ribs on the right valve and narrow, shallow radial grooves which are about a quarter of the width of the ribs. This number includes 2 to 3 riblets on the anterior and posterior shell margins. What we presume is the left valve (plate 2, fig. 13) has 20 round-topped radial ribs with radial grooves slightly narrower than the radial ribs. The ribs are not medially sulcate and are unornamented except for very small nodes scattered across the shell — ribs and interspaces on both valves. This last feature serves to refer these two valves to the same species. The posterior auricle on the right valve is large and inclined slightly towards the posterior and is unornamented. Four major and possibly two minor ctenidia are present below the posterior auricle. The anterior auricle is small, inclined towards the posterior and is ornamented by at least four radial ribs with wide interspaces. The left valve (plate 2, fig. 13) is ornamented by about 21 unornamented rounded radial ribs with interspaces from about $1 / 3$ to $2 / 3$ the width of the ribs and steep sides. Its anterior auricle is mostly missing but appears to have at least one rounded radial rib. The posterior auricle has five, and part of a sixth rounded near its base, radial ribs after half the width of the interspaces; the anterior auricle is mostly missing but does show one faint radial rib. The posterior auricle has five and part of a sixth round-topped, kinked, radial ribs with interspaces about twice their width.

As the name implies this form is closest to Chlamys egregius and may be this species although there are significant differences between the type specimen and our specimens. However, C. egregius is a rare species and the extent of its variability is unknown. Chlamys egregius was described as having a smaller umbonal angle of about $70^{\circ}$, whereas our specimens has an angle of about $87^{\circ}$, also the ribs are wider and interspaces narrower on the right valve of the Bloomfield Quarry species.

\section{Chlamys cf. C. hastata (Sowerby, 1842) Plate 2, figure 14}

The third species, Chlamys cf. C. hastata is large, with undivided ribs and small, weak, slightly intertwining cords between the ribs. The ribs, about 20 on the illustrated right valve, are high in the center with slight shelves to either side and have small rough scales down the center. The auricle on the right valve has 3-4 fine radial ribs with wide interspaces and the end of the auricle is vertical. The byssal notch is wide and well indented. This specimen is provisionally referred to C. hastata and is similar to the form previously identified as $C$. hastata hericeus (Gould, 1850) in the form and sculpture on the ribs but is provisionally identified because of its worn condition. Chlamys hastata and C. hastata hericeus [synonymized by Coan and others (2000)] as reported by Moore (1984) occurs in the late Miocene to Holocene. Modern occurrences (Coan and others, 2000) are from the Kenai Peninsula, Alaska, south to San Diego, California, at water depths from the intertidal zone to $160 \mathrm{~m}$.

\section{Patinopecten sp. indeterminate}

Several shell fragments are identified as Patinopecten sp. indeterminate based on the shell shape and broad, medially sulcate, flat topped ribs that are broader than the interspaces. Unfortunately, they are incomplete and do not allow for precise identification.

\section{Swiftopecten parmeleei (Dall, 1898) Plate 2, figures 8,9}

Specimens identified as well-worn Swiftopecten parmeleei (Dall, 1898) are represented at Bloomfield Quarry by two well-preserved specimens from CAS locality 54135 and a partial internal mold. These specimens are remarkably similar to Chlamys ("Chlamys") coatsi MacNeil (1967) from the Pleistocene of Alaska differing in the tops of the major ribs 
being smooth and in having microsculpture over the valves especially on the margins. As compiled by Moore (1984), $S$. parmeleei has also been reported from the Careaga Sandstone and Castaic, Etchegoin, Fernando, Niguel (as Capistrano), Pico, Purisima, San Diego, and San Joaquin Formations, as well as the Wildcat Group. These formations indicate the species ranges from "Jacalitos" to "San Joaquin" CPMS in age, or late Miocene through Pliocene.

Family Lucinidae Fleming, 1828

Lucinoma annulatum Reeve, 1850

Three articulated specimens and a few fragments are assigned to Lucinoma annulatum based on their size, shape, and strong comarginal sculpture. There has been much confusion in the early literature between $L$. annulatum and L. acutilineata (Conrad, 1849) (Moore, 1963 [1964]; Powell, 1998). Post-Moore (1963]) literature indicates that L. acutilineata occurs questionably from the Juanian Pacific Northwest provincial molluscan stage (PNPMS; upper Oligocene and lower Miocene) and Pillarian PNPMS (lower Miocene) to Newportian PNPMS (lower and middle Miocene) (Moore and Addicott, 1987), whereas L. annulatum (Reeve, 1850) ranges in rocks from Moclipsian PNPMS (most of the Pliocene) to Holocene in the Pacific Northwest (Addicott, 1976a). However, Roth (1979) believes the range of L. annulatum extended back to the Wishkahan PNPMS (early late Miocene), but this record has not been published. To add to the confusion, L. annulatum has been reported in rocks as old as Eocene in the Russian Federation (Kafanov and Ogasawara, 2003). In California L. annulatum is reported in rocks from the "Margaritan" CPMS (Powell, 2007; late middle to middle late Miocene) to middle Pleistocene (Clark, 1931). Modern occurrences of L. annulatum in the eastern Pacific are from Prince William Sound, Alaska, south to Guaymas, Sonora, Mexico, including the Gulf of California as far south as Isla Monserrate, at water depths between the intertidal zone and $665 \mathrm{~m}$ in sand (Coan and others, 2000).

Family Veneridae Rafinesque, 1815 Leukoma sp. indeterminate

A single shell fragment from CAS locality 54135 with moderately strong radial and comarginal sculpture resembles the genus Leukoma and is questionably assigned to that genus. In the eastern Pacific the genus Leukoma is wide-ranging and not ecologically significant because of its wide latitudinal and depth ranges.

\section{Family Cardiidae Lamarck, 1809 \\ Cardiidae, indeterminate Plate 3, figure 6}

All specimens of Cardiidae from Bloomfield Quarry are referred to as indeterminate Cardiidae. Seven specimens from CAS locality 54135 , both casts and molds, resemble the genus
Clinocardium, but lack sufficient detail to identify them confidently to that genus. In addition, three internal molds from CAS locality 54136 are identified as indeterminate Cardiidae based on their size and shape. No sculpture is preserved and the outline of the shells is incomplete, so further identification is impossible.

\section{Family Mactridae Lamarck, 1809 Mactridae, indeterminate}

One internal mold from CAS locality 54135 resembles the family Mactridae in shape and size, but does not allow for a confident identification.

Family Tellinidae Blainville, 1814

Macoma aff. M. indentata indentata Carpenter, 1864 Plate 3, figure 1

A single specimen from CAS locality 54135 is identified as Macoma aff. M. indentata s.s. based on its size, shape and bent posterior end. However, the Bloomfield Quarry specimen is shorter, higher, and the posterior dorsal margin is inclined more than the nominal species. In addition, two specimens from the same collection are referred to indeterminate Macoma (plate 3, figs. 2, 3) lacking distinguishing features or shape because of poor preservation.

\section{Tellina? sp. indeterminate}

Several large elongate tellinids are provisionally identified as Tellina? based on their size and shape alone as the lateral hinge teeth are not visible. They somewhat resemble Tellina emacerata Conrad (1849) in shell outline but not exactly and were broken through the umbo during preservation making precise identification impossible.

$$
\begin{gathered}
\text { Family Myidae Lamarck, } 1809 \\
\text { Cryptomya californica (Conrad, 1837) }
\end{gathered}
$$

Abundant Cryptomya californica are in collections from CAS localities 54135 and 54136 as internal molds and fewer specimens with shells of one or both valves still preserved. Cryptomya californica [synonyms C. ovalis Conrad (1857) and C. quadrata Arnold (1909 [1910])] commonly lives in sand and sandy mud from the intertidal zone to $80 \mathrm{~m}$ (Foster, 1991) along the open coast from Montagu Island, Alaska south to Bayovar, Peru, in the eastern Pacific (Coan and others, 2000). This species is always associated with larger burrowing invertebrates including the shrimp Callianassa and Upogebia and the spoon worm Urechis (Annelida: Echiura) (Coan and others, 2000). Grant and Gale (1931) reported this species as a fossil from the Miocene to Pleistocene from western North America, citing occurrences from Washington south to Baja California Sur, Mexico. Based on the formations reported by Grant and Gale (1931), this species likely ranges from the "Margaritan" CPMS to Holocene. The "Margaritan" CPMS occurrence was confirmed by Powell (2007). 
Family Teredinidae Rafinesque, 1815

Teredo(?) sp. indeterminate

A single specimen from CAS locality 54135 resembles Teredo bored wood. No shell is present so further identification is impossible.

Family Hiatellidae Gray, 1824

Panopea sp. indeterminate

A single valve and fragment of a second valve from CAS locality 54135 are assigned to indeterminate Panopea based on their size shape and comarginal sculpture. Recently, Vadopaias and others (2010) separated the two species synonymized by Moore (1963 [1964]), giving distinguishing characters for each. They referred fossil specimens mostly to $P$. abrupta (Conrad, 1849) and modern specimens to $P$. generosa Gould (1850). Panopea resembling these two species are common in the Neogene of California from the early Miocene (Addicott, 1976a), possibly middle Oligocene (Hickman, 1969), to Holocene and no attempt has been made here or elsewhere to differentiate these two species in the fossil record. It is assumed that $P$. generosa is not restricted to the Holocene, but its stratigraphic range remains unknown.

\section{Tresus pajaroanus (Conrad, 1857) Plate 3 , figures 5,7}

Abundant internal molds of Tresus pajaroanus (Conrad, 1857), some with original shell, occur at CAS localities 54135 and 54136. Some of the specimens are crushed or partially crushed but almost all are articulated and show the distinctive outline of this species allowing identification to species. Interestingly, most of the specimens are small for this species and are rarely in excess of $100 \mathrm{~mm}$ maximum length. Tresus pajaroanus occurs from Washington to southern California in rocks of late Miocene age, judging by its occurrences in Grant and Gale (1931), to middle Pleistocene (Powell, 1998).

\section{Family Solenidae Lamarck, 1809 Solen $s p$. indeterminate}

Six incomplete valves resembling the genus Solen are present from CAS locality 54135. Unfortunately, they are not well enough preserved to assign to species.

\section{Family Pharidae H. Adams and A. Adams, 1856 Ensis $s p$. indeterminate Plate 3, figure 4}

A few bivalve cast fragments from CAS locality 54135 have an internal buttress that appears to run from the dorsal to ventral surface. These specimens are identified as an indeterminate species of Ensis.
Class Gastropoda Cuvier, 1795

Family Trochidae Rafinesque, 1815

Trochidae indeterminate

A single internal mold from CAS locality 54136 consisting of the ultimate and most of the penultimate whorl is identified as an indeterminate Trochidae.

Family Fissurellidae Fleming, 1822

Fissurellidae indeterminate

Two incomplete specimens from CAS locality 54135 are assigned to the indeterminate Fissurellidae on the basis of the shell form. The distinction between the genera Diodora and Fissurella is based on the callus inside the apex, which is squared posteriorly in Diodora. This feature cannot be observed in the Bloomfield specimens so both genera are discussed here. The larger specimen is incomplete, about $29.6 \mathrm{~mm}$ wide and $35.2 \mathrm{~mm}$ high, showing fine, low, threadlike straight primary radial ribs with three very low rounded secondary radial ribs, whereas the smaller is $19.0 \mathrm{~mm}$ high and $15.7 \mathrm{~mm}$ wide and shows primary radial ribs crossed by secondary circular ribs and three tertiary radial ribs between the primary ribs.

Neogene Fissurella and Diodora are unusual as fossils in California with only eight species reported-Diodora arnoldi McLean (1966) [as Fissuridae murina Carpenter, ms., fide Arnold, 1907)], Diodora aspera (Rathke, 1833), Diodora cayenensis (Lamarck, 1822), Diodora (Diodora) n. sp. of Addicott (1970), Diodora? n. sp. of Addicott (1970), Diodora subelliptica (Nomland, 1916), Diodora unica (Nomland, 1917), and Fissurella rixfordi Hertlein (1928). Arnold (1907) reported Diodora arnoldi (as Fissuridae murina) from the Repetto Formation in Los Angeles; however, Woodring (1938) rejected it as a doubtful Repetto fossil. Diodora aspera, reported from the Pliocene to Holocene, is easily identified by its larger, higher shell and different sculpture with primary, tertiary, and secondary radial ribs. The Atlantic Diodora cayenensis (Lamarck, 1822) is reported from the late Miocene "Imperial" Formation in south-central California (Schremp, 1981). It is easily distinguished from the present specimens by its sculpture. The early Miocene Diodora $(D$. $)$ n. sp. of Addicott (1970) is easily distinguished by having abundant equally spaced, fine radial ribs as in Fissurella rixfordi Hertlein, 1928. Diodora? n. sp. of Addicott (1970) (lower Miocene) is remarkably similar to the Bloomfield Quarry specimen although less than half the length. It also differs in only having a single secondary riblet between the primary radial ribs. Diodora subelliptica Nomland reported from the Jacalitos Formation and D. unica (Nomland) from the upper Etchegoin Formation (Nomland, 1917) both differ having a higher apex and numerous, generally uniform, radial ribs with narrow interspaces. In addition, there is a single poorly 
preserved fissurellid limpet from the middle Miocene Topanga Formation in Los Angeles County (LACM invertebrate paleontology collections) that is easily distinguished in lacking the circular ribs. These specimens likely represent a new species but they are not described until more complete specimens can be obtained.

\section{Family Neritidae Rafinesque, 1815 Neritidae indeterminate}

A single partially crushed, internal mold from CAS locality 54135 is identified as an indeterminate Neritidae similar to Nerita based on its shape and a few patches of spiral sculpture that are preserved on the specimen. These spiral ribs consist of a larger broad, flat-topped rib that in some cases appears medially sulcate separated by a rib about half the width of the larger ribs and separated from one another by a shallow trough about the width of the smaller ribs. The only Nerita reported from the Neogene of coastal California is $N$. joaquinensis Addicott (1970) from the middle Miocene Round Mountain Silt in Kern County, California (Addicott, 1970; Vermeij and others, 2009). Other Neritidae genera occur in the Late Cretaceous and Paleogene of California and Baja California, Mexico (Woods and Saul, 1986; Squires, 1992; Squires, 1993; Squires and Saul, 1993; questionably by Squires and Goedert, 1996; Squires and Saul, 2002), but they are not similar to the single incomplete Bloomfield Quarry specimen.

\section{Family Calyptraeidae Lamarck, 1809}

California Neogene Calyptraeidae are divided into two genera Calyptraea and Trochita, which are in need of revision. After a review of the literature and some museum specimens, they can be divided into six basic groups. The two genera that have similar shells were originally divided with Calyptraea having no or fine radial sculpture, whereas Trochita has medium to coarse sculpture. Because radial sculpture is variable within a species, the genera are divided as follows here-(1) species that are smooth and lack radial sculpture are identified as Calyptraea, whereas (2) species with radial sculpture are referred to the genus Trochita. The genus Trochita (as here defined) includes nine species in the Neogene of California-T. coreyi Addicott (1970), $T$. costellata (Conrad, 1857), T. costella panzana (Loel and Corey, 1932), T. diabloensis Clark (1915), T. diegoana (Conrad, 1855), T. inornata (Gabb, 1869), T. martini Clark (1915), T. radians (Lamarck, 1815) of authors, not of Lamarck, 1815, and T. spirata (Forbes, 1852). These Trochita are further divided into five groups.

Trochita group 1 consists of Trochita coreyi and T. filosa (Gabb, 1869) that are easily distinguished from other members of the genus in California by their fine, numerous radial ribs. They can be distinguished from one another in that $T$. coreyi is generally higher than wide with shouldered whorl profile, whereas T. filosa is generally wider than high with a smooth profile. In addition, $T$. coreyi is generally larger than
T. filosa. Trochita group 1 species would previously have been attributed to Calyptraea.

Woodring (1957), following Grant and Gale (1931), suggested that all heavy-ribbed Miocene forms be synonymized under T. trochiformis Born (1778). However, there are differences among several of the California fossil taxa that will be outlined below and that allow for further differentiation. From photographs in the literature four coarser ribbed Trochita forms are recognized here in California. Trochita group 2 are small specimens ( $<20 \mathrm{~mm}$ diameter), generally wider than high, with smooth whorl profiles, and slightly curved radial sculpture narrower than the interspaces (Arnold, 1908; English, 1914; Moody, 1916; Woodring and Bramlette, 1950, plate 13, fig. 19; Zinsmeister, 1970; T. radians of authors), which appears to be restricted to the Pliocene. Trochita group 3 are larger specimens $(>20 \mathrm{~mm}$ diameter) that resemble modern specimens of T. spirata and (or) T. trochiformis and are generally wider than high, with slightly oblique radial ribs that are wider than the interspaces, and with a smooth to slightly shouldered whorl profile (Clark, 1915, plate 70m, fig. 8, Calyptraea martini; Loel and Corey, 1932, plate 63, fig. 11, C. costellata). This group is restricted to the Miocene. Trochita group 4 are larger specimens, with a generally smooth whorl profile and broad flat-topped spiral ribs and narrow sharp interspaces (Clark, 1915, plate 70, fig. 9, T. diabloensis), also restricted to the Miocene. Lastly is Trochita group 5 that consists of T. costellata panzana (Loel and Corey 1932, plate 63, fig. 10), which is much higher than wide with a strongly shouldered profile. This species appears to be restricted to its type locality and could be a local ecological variant.

Specimens from group 2 in California are referred to an undescribed Trochita. Several authors refer these specimens to Trochita radians; however, T. radians is a Caribbean and northern South American species that ranges in age from the Miocene to Pleistocene (Fossilworks, 2011) and is not found along the west coast of North America. Specimens referred to this species by west coast authors (Martin, 1916; Clark, 1918; Woodring and Bramlette, 1950) are in error. They were referred to T. trochiformis by Grant and Gale (1931) and Woodring (1957), but the authors do not agree with this synonymy and considers this taxon to be undescribed.

Group 3 includes the modern T. spirata and T. trochiformis, which Keen (1971) separates based on size, color, sculpture, and distribution, but as fossils they are indistinguishable. Trochita spirata has a modern range from Mazatlán, Mexico, south to the Gulf of Tehuantepec, Mexico, and T. trochiformis occurs from Manta, Ecuador, south to Valparaiso, Chile. Fossil specimens are often poorly preserved and are not referable to either species with any degree of confidence. Also, the name $T$. trochiformis has been used for Neogene fossils in southern and central California by Grant and Gale (1931) and followed by later authors, although this does not make sense biogeographically as $T$. trochiformis occurs further from southern California than does T. spirata. The California Neogene specimens need a new name but that must await further research. 


\author{
Trochita cf. T. diabloensis (Clark, 1915) \\ Plate 3, figure 11
}

About 20 incomplete specimens and latex casts from CAS locality 54315 , and a few from CAS locality 54316 , are identified as Trochita $\mathrm{cf}$. T. diabloensis. The best-preserved specimen is about $7 \mathrm{~cm}$ in diameter and ornamented by broadly round, straight, radial ribs, with narrow interspaces. In addition, many specimens show moderately thick rounded radial ribs more prominent in the lower part of the shell and separated by a narrow, broadly rounded interspace. The ribs are curved toward the leading margin of the shell. The umbo appears significantly eccentric. Trochita diabloensis has been only been reported previously from the lower San Pablo Group around Mount Diablo in Contra Costa County (Clark 1915), which is likely referable to the "Margaritan" CPMS. Better preserved specimens may show these specimens to be a new species.

\section{Crepidula princeps Conrad, 1855 \\ Plate 3, figure 8}

Abundant internal molds from CAS locality 53135 and a single fragment with some original shell near the umbonal region from CAS locality 53136 are identified as Crepidula princeps based on its size and shape. Crepidula princeps ranges from Alaska to Baja California, Mexico, in rocks from Miocene to middle Pleistocene (Grant and Gale, 1931; Powell and others, 2010). The youngest occurrence is well dated, but early occurrences of $C$. princeps are poorly dated because this species is easily confused with C. praerupta (Conrad, 1849) and can only be distinguished when the internal shelf is exposed. Addicott (1970) reports early Miocene occurrences from the Vaqueros Formation in the Santa Cruz Mountains citing Arnold (1908) and from the Caliente Range citing oral communication (1963) with Jack G. Vedder. He also reports it from the Jewett Sand in the Kern River area also citing an early Miocene age. Recently (Hosford Scheirer and Magoon, 2007) cite the age of the Jewett Sand as 25 to $21 \mathrm{Ma}$ or late Oligocene to early Miocene. Therefore, an early Miocene to middle Pleistocene age range for $C$. princeps seems reasonable.

\section{Crepidula sp. indeterminate}

Ten small internal molds from CAS locality 54136 are referred to indeterminate Crepidula. They could represent immature $C$. princeps or another species, but their preservation does not allow for identification beyond the genus level.

\section{Family Naticidae Guilding, 1834 \\ Naticidae, indeterminate}

Eight internal molds from CAS locality 54136 are identified as indeterminate Naticidae based on their size and shape. In addition, numerous specimens from CAS locality 54135 and two minute specimens with original shells are similarly identified. A more detailed determination is fruitless as the specimens lack distinguishing features.

\author{
Family Nassariidae Iredale, 1916 \\ Desmondia sp. indeterminate
}

Most specimens from Bloomfield Quarry are too poorly preserved for precise identification and are here referred to an indeterminate Nassariidae. However, a few better-preserved specimens are discussed below. Specifically, two small internal molds and one incomplete specimen from CAS locality 54135 resemble the genus Desmondia based on their shape and strong radial sculpture but the whorls are more stepped than $D$. perpinguis (Hinds, 1844 [1845]) and are identified as indeterminate Desmondia sp.

\section{Caesia cf. C. grammatus Dall, 1917}

One crushed and incomplete specimen and a partial cast from CAS locality 54135 strongly resembles small Caesia grammatus and are provisionally identified (cf.) as that species based on their shape and strong concentric sculpture. According to Addicott (1965) Caesia grammatus is restricted to Pliocene age deposits (see also Powell and others, 2010, p. 23). The occurrence of this species in the late Miocene would represent a chronostratigraphic range extension, however the provisional identification prevents the extension.

\section{Family Muricidae Rafinesque, 1815 Ocinebrina? sp. indeterminate}

Three small shell fragments from CAS locality 54135 show coarse, radial sculpture on what appears to be a fusiform shell. The radial sculpture and shell form resembles that seen on the genus Ocinebrina in the eastern Pacific. These specimens are not complete enough to identify properly and are here assigned questionably to the genus Ocinebrina.

\section{Nucella n. sp. aff. N. etchegoinensis (Arnold, 1909 [1910]) Plate 3, figures 9, 10}

Abundant entire whole and partial specimens of small juveniles to larger adult shells previously attributed to Nucella n. sp.? aff. N. lamellosa (Gmelin, 1791) (Powell and others, 2004) are present from CAS locality 54135, and six immature specimens are present from CAS locality 54136 . These specimens are here referred to N. n. sp., aff. N. etchegoinensis and are being described separately by the senior author and Barry Roth. The best preserved of these specimens resemble $N$. etchegoinensis, ribbed variety, illustrated by Woodring and others (1940, plate 36, figs. 1, 7), but have a maximum height $(37 \mathrm{~mm})$, at best only about half the height of Woodring's illustrated species (plate 36, figs. 1, 7; 73 and $83 \mathrm{~mm}$, respectively). In addition, the Bloomfield Quarry specimens have three to five subdued denticles along the inside of the outer lip, along with a broadly flattened and flaring outer lip. These features are not present in $N$. etchegoinensis and only the first is very rarely observed in $N$. lamellosa which are more pronounced in the Bloomfield Quarry specimens than in any form of N. lamellosa observed. 
Grant and Gale (1931) synonymized N. etchegoinensis under $N$. lamellosa, because the latter species shows remarkably modern variability (see Kincade, 1957); however, none of the specimens illustrated by Kincade (1957) or in any other publication illustrates modern Nucella that compare favorably with $N$. etchegoinensis or the Bloomfield Quarry specimens. Nucella appears to be over-synonymized in the California Tertiary. In particular N. etchegoinensis and the Bloomfield Quarry species have no modern equivalent. Nucella etchegoinensis has been reported previously from the Etchegoin-San Joaquin Formations (Arnold, 1909; Pack and English, 1914; Woodring and others 1940) and Pancho Rico Formation (Durham and Addicott, 1965) in central California and the Empire Formation (restricted) at Cape Blanco, Oregon (Addicott, 1980, 1983), indicating a possible late Miocene ("Jacalitos" CPMS) to Pliocene ("San Joaquin" CPMS) age range. Nucella lamellosa excluding $N$. etchegoinensis has been reported from late Miocene to Pliocene Purisima Formation (Arnold, 1908; Martin, 1916; Allen, 1945; Glen, 1959; Touring, 1959; Cummings and others, 1962; Perry, 1993), Pliocene Foxen Mudstone, both members of the Careaga Sandstone (Woodring and others, 1943; Woodring and Bramlette, 1950), "Santa Margarita Sandstone" (Clark, 1981) [although this unit is considered late Miocene elsewhere, mollusks reported from the collection containing $N$. lamellosa in Clark (1981) also contain Patinopecten healeyi (Arnold, 1909), which is restricted to the Pliocene], middle Pliocene to early Pleistocene San Diego Formation (Vendrasco and others, 2012), and coastal Pleistocene terraces and basin deposits (Arnold, 1903; Woodring and others, 1946; Valentine, 1958; Campbell and Valentine, 1979; Valentine, 1980) in California. These occurrences suggest an age range of possibly late Miocene ("Jacalitos" or "Etchegoin" CPMS) to Holocene. The older late Miocene age may be supported by Addicott (1976b), who reported the lowest stratigraphic occurrence of $N$. lamellosa in the Wishkahan Pacific Northwest provincial molluscan stage (PNPMS; late Miocene); however, the Wishkahan PNPMS may be of limited stratigraphic use (Armentrout, 1981; Prothero and others, 2001). California Tertiary Nucella are in need of review, but that is beyond the scope of this paper.

\section{Nucella sp. indeterminate}

A number of immature, poorly preserved Nucella from CAS locality 54135 are not identifiable to species.

Family Buccinidae Rafinesque, 1815

$$
\text { Lirabuccinum portolaensis (Arnold, 1908)? }
$$

Abundant poorly preserved and commonly crushed specimens of a moderate sized neogastropod are questionably attributed to Lirabuccinum portolaensis (Arnold, 1908) based on their size, shape, and spiral sculpture. From occurrences reported in the literature (Arnold, 1908; Martin, 1916; Allen, 1945, Adegoke, 1969; Addicott and others, 1978; Perry, 1993), Powell (1998) suggested a late Miocene to late Pliocene stratigraphic range for L. portolaensis, although Powell and others
(2004) further suggested that most, if not all, of its occurrences appear to be restricted to the Pliocene part of their respective formations. The Bloomfield Quarry deposits are definitely late Miocene but the specimens examined do not allow for a confident identification, so the Powell and others (2004) hypothesis is neither confirmed nor refuted.

\section{Arthropods}

Phylum Arthropoda Latreille, 1829

Class Maxillopoda Dahl, 1956 (Barnacles)

Family Balanidae Leach, 1817

Barnacles from Bloomfield Quarry were described and discussed in detail by Zullo and Guruswami-Naidu (1982) and no new information is provided here. They recognized five species of which Balanus irradians and Notomegabalanus? insperatus were described as new. Also identified are $B$. aff. $B$. nubilus Darwin (1854), B. cf. B. irradians Zullo and Guruswami-Naidu (1982), and an indeterminate Balanus.

Class Malacostraca Latreille, 1802

Family Callianassidae Dana, 1852

Callianassa? sp. indeterminate

A single cheliped, questionably (?) assigned to the genus Callianassa based on its size and shape, is present from CAS locality 54135. Callianassa are common intertidal and subtidal burrowers along the California coast. They have a fossil record in the western Pacific going back to at least the Late Cretaceous (Vega and others, 1995; Hyzny and others, 2013).

\section{Cancer sp. indeterminate}

The genus Cancer is well represented in the fossil record of California (Nations, 1975) from the late Miocene to Pleistocene and it is still common today off the California coast. The specimens identified here are indeterminate chelipeds provisionally referred to genus.

\section{Vertebrates}

Phylum Chordata Bateson, 1885

\section{Fishes by Douglas J. Long}

Class Chondrichthyes Huxley, 1880

Superorder Galeomorphii Compagno, 1973

Order Hexanchiformes Compagno, 1973

Family Hexanchidae Gray, 1851

Genus Hexanchus Rafinesque, 1810

Hexanchus griseus (Bonnaterre, 1788)

Plate 4, figures 1, 2

Referred Specimens_-Specimens referred to this species include UCMP 125599, a complete upper anterior tooth; 
UCMP 125600, a complete lower right lateral tooth; UCMP 125601 , an isolated anterior cusp broken from an upper tooth; and UCMP 125602, an isolated anterior cusp broken from a lower lateral tooth.

Remarks-The extant sixgill shark Hexanchus griseus, and its Neogene synonym $H$. gigas, is known from the Miocene through late Pleistocene of western North America, as well as additional localities scattered worldwide (Welton, 1979; Long, 1993a, 1994; Cappetta, 2012). It currently has a worldwide distribution around oceanic islands and along continental shelves and slopes from the tropics to subpolar zones, including western North America, but most common in water below $200 \mathrm{~m}$; in cool-temperate areas this species can be found nearshore and in water shallower than $60 \mathrm{~m}$ and often have both diel and seasonal migrations between deep and shallow water (Andrews and others, 2009; Ebert and Compagno, 2013).

Order Lamnifornes Berg, 1958

Family Lamnidae Müller and Henle, 1838

Genus Isurus Rafinesque, 1810

Isurus oxyrinchus Rafinesque, 1810

Plate 4, figure 3

Referred Specimens-UCMP 125605, a complete lateral tooth clearly identifiable as the extant mako shark Isurus oxyrinchus.

Remarks-This species occurs in late Miocene to late Pleistocene localities in the western United States and Mexico, as well as in various localities throughout eastern North America, South America, Europe, and Asia but may also occur earlier in the Miocene, although there is confusion among a number of various Paleogene and Neogene species that may not all be valid (Boessenecker, 2011; Fitch, 1964, 1967, 1968; Long, 1993a, 1994; Cappetta, 2012). Currently, I. oxyrinchus is also found worldwide from tropical to cool-temperate waters, including coastal areas above the continental shelf, and into pelagic areas over deep ocean basins; in California it is more common in warmer areas south of Point Conception, Santa Barbara County, but will move seasonally north as southern waters warm and extend northward (Compagno, 2001; Ebert, 2003).

Family Cetorhinidae Gill, 1862 Cetorhinus maximus (Gunnerus, 1765)

Referred Specimens - Broken and incomplete gill rakers, UCMP 125603; and UCMP125604; which contain the articulating base of the raker that is used to identify the species as the extant Cetorhinus maximus (Welton, 2013a,b, 2015).

Remarks-This species is known from the late Miocene through the Pleistocene of the West Coast of the United States and has been found in late Miocene to late Pleistocene localities worldwide including eastern North America, Europe, South America, and Japan (Boessenecker, 2011; Cappetta, 2012; Long, 1993a,b, 1994; Welton, 2013a,b). Basking sharks are filter feeders that live along subpolar to warmtemperate coasts above the continental shelf where it feeds on zooplankton and can sometimes be found very close to the shore, often occurring just beyond the surf zone and into enclosed bays (Ebert, 2003). Along the west coast of North America, this species is found from Alaska south to the Baja Peninsula and the Gulf of California, Mexico (Baldwin, 1961; Sandoval-Castillo and others 2008), with an apparent absence in the equatorial tropics and subtropics, and then ranges in the southern hemisphere from Ecuador to southern Chile (Hernández and others, 2010).
Superorder Batoidea Compagno, 1973
Order Myliobatiformes Compagno, 1973
Family Myliobatidae Bonaparte, 1838
Genus Myliobatis Cuvier, 1816
Myliobatis californica Gill, 1865

Referred Specimens-UCMP 125606, UCMP 128199, UCMP 128200, UCMP 128201, each a single medial tooth plate; UCMP 128202, UCMP 128203, UCMP128204, UCMP 128205 , each a lateral tooth plate.

Remarks - These tooth plates are identifiable to the extant bat stingray Myliobatis californica, an epibenthic coastal species of stingray that ranges from the coast of Oregon south through the Gulf of California, Mexico, inhabiting bays, estuaries, and coastal areas above $50 \mathrm{~m}$ depth (Ebert, 2003). The fossil record of this species on the west coast of North America ranges from the late Pleistocene (Fitch, 1964, 1967, 1970; Long 1993b), the late Pliocene (Fitch and Reimer, 1967) and into the late Miocene (D.J. Long, unpublished data), so these specimens are well within the paleochronological range of the species.

Class Osteichthyes Huxley, 1880

Subclass Actinopterygii Klein, 1885

Subdivision Teleostei Müller, 1846

Order Salmoniformes Bleeker, 1859

Genus Oncorhynchus Suckley, 1861

Oncorhynchus sp. indeterminate

Referred Specimens-UCMP 125609, a fragmented thoracic vertebra showing the fine bony lattice-like organization around the external radial edge of the vertebra seen in the modern salmonid genus Oncorhynchus.

Remarks - This fragmented vertebra, although it may not be identifiable to any particular salmon species, is important in being a relatively early record of Oncorhynchus in West Coast marine localities. Other than the large salmon Oncorhynchus rostratus, which is relatively abundant in late Miocene and early Pliocene deposits (Sankey and others, 2016), fossil salmonids are surprisingly uncommon in late Cenozoic marine deposits of the Western United States. By the late Miocene-early Pliocene, the different extant species of Pacific salmon had already evolved (Smith, 1992; Stearley, 1992; Montgomery, 2000). However, only one late Pleistocene salmon, Oncorhynchus tshawytscha, has been collected from a late Pleistocene marine locality in the northern California Crannell Junction site near Arcata (Fitch, 1970). 
Superorder Clupeomorpha Greenwood and others, 1966

Order Clupeiformes Bleeker, 1859

Family Clupeidae Cuvier, 1817

Genus Sardinops Hubbs, 1929

Sardinops sp. indeterminate

Referred Specimens-UCMP 125622 and

UCMP125623, both single isolated thoracic vertebrae.

Remarks-Sardinops has several species in the eastern

Pacific, including the extant Sardinops caeruleus found along the west coast of North America (Whitehead, 1985) and is also known from the late Pleistocene of California (Long, 1993b). Fitch (1970) found no Sardinops otoliths in any early Pleistocene or late Pliocene deposits in California, but these fish shed scales throughout their lifetime that can accumulate in abundance in marine sediments (Baumgartner and others, 1992). Grant and Bowen (1998) show that Sardinops, as a world-wide genus, has been in existence for at least 20 million years, and although other clupeoid fishes are well known from Miocene deposits in California (Fierstine and others, 2012), none have been assigned to Sardinops. These fossils appear to be the earliest record of Sardinops in the late Neogene of the west coast of the North America; however, due to the fragmentary nature of these specimens, and to the lack of comparative material from any other late Miocene and Pliocene species, the identification herein remains only as Sardinops sp.

Superorder Paracanthopterygii Greenwood and others, 1966 Order Gadiformes Goodrich, 1909

Family Merlucciidae Gill, 1884

Genus Merluccius Rafinesque, 1810

Merluccius sp. indeterminate

Referred Specimens-UCMP 125638, several damaged isolated vertebrae; UCMP 287609 and UCMP 287610, each a slightly damaged thoracic vertebrae embedded in a sandstone block; all specimens identifiable as the hake Merluccius.

Remarks-The extant Merluccius productus is known from the late Pleistocene into the late Pliocene from numerous localities on the west coast of North America, (Fitch and Reimer, 1967; Fitch, 1969; Fitch and Lavenberg, 1971; Long, 1993b; Welton, 2015). Although the genus Merluccius is known from fossils dating back to the Oligocene in Europe and central Asia, and genetic divergence scenarios also support this time frame (Campbell, 1929; Roldan and others, 1999; Quinteiro and others, 2000), no pre-Pliocene fossils of Merluccius are yet conclusively identified from western North America, so these specimens may be the earliest record for the genus in this region. A somewhat enigmatic early Pliocene species Promerluccius venturaensis David (1956) is known from a single scale (Fierstine and others, 2012), so there cannot be any equitable taxonomic comparisons between our fossil Merluccius vertebrae and $M$. venturaensis. Until more complete and more extensive osteological material can be collected from this site and critically examined, these specimens will only be referred to as Merluccius sp. The extant Merluccius productus is usually a shoaling species in deeper waters $(45-1,000 \mathrm{~m})$ of the Continental Shelf from southern Baja California north to Alaska, but they are sometimes known to move into nearshore and occasionally even estuarine waters (Cohen and others, 1990).

Superorder Acanthopterygii Greenwood and others, 1966 Order Scorpaeniformes Greenwood and others, 1966 Family Sebastidae Kaup, 1873 Genus Sebastes Cuvier, 1829 Sebastes sp. indeterminate

Referred Specimens - UCMP 125632, UCMP 125633, UCMP 125634, UCMP 125635, UCMP125636, and UCMP 125637, each a single isolated vertebra.

Remarks-These specimens are from the genus Sebastes, a diverse, common and widespread genus of scorpionfishes along the western coast of North America consisting of more than 60 species (Love and others, 2002). Although different living species can be distinguished by their skull morphology (Miller and Lea, 1972) and otoliths (Lowry, 2011), there is very little consistent variation in the vertebrae between species to make a confident identification to anything more than the generic level.

The genus Sebastes dates back to at least the late Miocene, being represented by several ancestral taxa (see review in Fierstine and others, 2012), and species diversity in Sebastes is high by the Pleistocene, with many extant species represented (Fitch 1964; 1967, 1970; Fitch and Lavenberg, 1971; Long, 1993b; Welton, 2015).

Order Perciformes Bleeker, 1859

Family Polyprionidae Oken, 1817

Genus Stereolepis Ayres, 1859

Stereolepis sp. indeterminate

Plate 4, figure 4

Referred Specimens-UCMP 125612, incomplete anterior vertebra; UCMP 125613, broken but mostly complete caudal vertebra.

Remarks-These two specimens represent the largest of the teleost fossils recorded from the Wilson Grove Formation, and are attributable to the wreckfish genus Stereolepis; however, these vertebrae are not necessarily diagnostic for the present-day species. The extant Black Sea Bass, Stereolepis gigas, has not yet been recorded from the fossil record in California (Fitch and Lavenberg, 1971; Fierstine and others 2012), although the large, dense bones should promote both preservation and discovery. Based on genetic phylogenies, the genus Stereolepis is thought to have originated in the Miocene (Near and others, 2013), and further genetic data shows the extant species was present in the waters of California and western Mexico since the late Pleistocene (Gaffney and others, 2007). These bones indicate that the genus was present in California since the late Miocene. Stereolepis gigas is a characteristic top-level predator in shallow coastal kelp forests from central California through to the Gulf of California, Mexico (House and others, 2016). 
Family Embiotocidae Agassiz, 1853

Embiotocidae indeterminate

Referred Specimens-UCMP 125617, lower lateral pharyngeal plate missing teeth; UCMP 125618, upper medial pharyngeal plate missing teeth.

Remarks-These two pharyngeal plates are of the same general morphology seen in the extant surfperches, but in comparison to all recent genera from the western coast of North America, they show minor differences and cannot be positively identifiable to any one genus and are considered Embiotocidae indeterminate. However, one specimen (UCMP 125618), a lower pharyngeal plate missing the teeth most resembles the extant genus Damalichthys, and another (UCMP 125618) an upper pharyngeal plate missing the teeth, is similar to the extant genus Embiotoca. Both of these fossils are incomplete, and it could be that some key osteological characters may have been lost from post-depositional erosion. Fitch (1969) had difficulty identifying surfperches based on their skeletal remains and left most identified as "embiotocids," although several extant taxa including Embiotoca and Damalichthys have been identified from their otoliths in late Pliocene and Pleistocene deposits (Fitch and Lavenberg, 1971, 1975; Fierstine and others 2012). Genetic data from Bernardi and Bucciarelli (1999) and Near and others (2013) suggest that surfperches rapidly radiated into many genera at the end of the Miocene and in the early Pliocene, so the fossils above would indicate representative ancestral forms rather than extant species. The Embiotocidae are abundant shallow-water fishes of kelp beds, seagrass meadows, and rocky intertidal habitats along the coasts and in the estuaries of western North America (Allen and Pondella, 2006).

Family Scombridae Cuvier, 1817 Genus Sarda Cuvier, 1829 Sarda sp. indeterminate

Referred Specimens-UCMP 125615, a single isolated vertebra, and locality UCMP 287611, a relatively complete vertebrae embedded in a block of sandstone; both specimens are attributable to the bonito Sarda.

Remarks-The extant Sarda chiliensis ranges in coastal and epipelagic offshore waters from southern Baja California well into southern Alaska but is more common in its northern range in warm-water years (Collette and Nauen, 1983). Although genetic and biogeographic evidence suggests this species has been present along the west coast of North America in the late Neogene (Vinas and others, 2010), it has no Pleistocene record, but Sarda, either as Sarda sp. or as the extinct $S$. stockii, is known from the middle to late Miocene in California (Fierstine and others, 2012). These specimens, although representing an important late Neogene record for the genus, are not associated with enough additional skeletal material to make a comparison between the extant S. chiliensis (Cuvier, 1832 [see Cuvier and Valenciennes, 1828-1849]) or the fossil S. stockii David (1943).

\author{
Order Pleuronectiformes \\ Family Paralichthyidae Regan, 1910 \\ Genus Paralichthys IGirard, 1858 \\ Paralichthys sp. indeterminate
}

Referred Specimens-UCMP 125614, a partially complete vertebrae missing haemel and neural spines.

Remarks - This large vertebra shows characteristics consistent with the large halibut Paralichthys. The extant California halibut $P$. californicus is known from the Pleistocene (Fitch, 1970; Long, 1993b) and the late Pliocene (Fitch and Reimer, 1967). Vertebrae of a late Miocene specimen from the Purisima Formation was identified as Paralichthys sp. (Boessenecker, 2011), and otoliths from Paralichthys sp. have been recovered from an unnamed Miocene locality near Bakersfield (Fitch and Lavenberg, 1971); these material have not been compared to the extinct Paralichthys antiquus (Jordan, 1924) from middle to late Miocene Monterey Formation deposits in central California (Fierstein and others, 2012). Therefore, this isolated vertebra cannot be confidently identified to either the extant $P$. californicus or the extinct $P$. antiquus and will be left as Paralichthys sp.

Modern-day P. californicus is found along the west coast of North America from northern California down through the Pacific coast of Baja California, Mexico, in shallow estuaries and along soft sand and silt substrates above the continental shelf (Allen, 1990).

\section{Marine Mammals by Robert W. Boessenecker}

\author{
Class Mammalia Linnaeus, 1758 \\ Order Carnivora Bowdich, 1821 \\ Family Odobenidae Allen, 1880 \\ Odobenidae indeterminate \\ Plate 5, figures 6-13
}

Referred Specimens-UCMP 125574, partial right innominate; UCMP 125576, left third metatarsal; UCMP 125579 , distal phalanx fragment.

Description-Innominate-UCMP 125575 includes the ischium and pubis, and the posterior part of the acetabulum, but is lacking the ilium (plate 5, figs. 12 and 13). The innominate is robust with a widely divergent ischium and pubis. Although incomplete, the obturator foramen is anteroposteriorly elongate and oval in shape. Near the posterior end of the preserved part of the ischium, the ischium is dorsally thickened where the broadly rounded dorsal spine of the ischium occurs. The pubis is straight and posteriorly directed. The part of the innominate adjacent to the acetabulum is robust and thickened; the acetabulum is deeply concave with a raised peripheral rim of bone.

Metatarsal - A single large and robust left metatarsal III is preserved (plate 5, figs. 8-11). The shaft is relatively long (113 $\mathrm{mm}$ total length). The proximal end is dorsoventrally expanded (39.9 mm greatest proximal width) and transversely 
compressed (21.86 mm least proximal width), and slight tubercles are developed at the proximal ventral and dorsal extremities. On the lateral surface of the proximal side, there are two oval to quadrate-shaped articular facets for the metatarsal IV, with a shallow concavity between. On the medial side there are two articular facets for the metatarsal II—a small facet dorsally and an elongate oval-shaped facet ventrally; again, a small concave surface extends between these facets. The ventral metatarsal II articulation facet is proximally continuous with the ectocuneiform facet, and forms a distinct convex tubercle in dorsal aspect. A plantar tuberosity occurs ventral to this facet. The shaft of the metatarsal III is circular in cross section. The distal end is slightly transversely wider than the shaft, and the trochlea is dorsoventrally convex. Ventrally, the trochlea exhibits a median ridge with two small fossae on either side, and small tubercles occur along the lateral and medial sides at the position of the distal trochlea.

Phalanx - A single distal fragment of a large phalanx is preserved (plate 5, figs. 6 and 7). The shaft appears to have been relatively wide, and the distal end is rectangular with a flat (not saddle-shaped) distal trochlea.

Remarks - These specimens can be differentiated from the contemporary otariid Thalassoleon in their larger size and more robust morphology, and are referred to the Odobenidae. However, they cannot be identified below the level of Odobenidae, either because they are elements that are not diagnostic at the subfamilial level (metatarsal) or because they are too incomplete (innominate) for detailed comparisons. The innominate can be compared with Dusignathus seftoni Deméré (1994b) (SDNHM 77891), cf. Pontolis magnus (USNM 335571), Valenictus chulavistensis Deméré (1994b) (SDNHM 83719), and Odobenus rosmarus (Linnaeus, 1758). UCMP 125575 differs from Odobenus in lacking small dorsal and ventrally projecting spines at the anterior end of the obturator foramen, and is generally less robust than innominata of Odobenus and Valenictus. It further differs from Valenictus in not being pachyosteosclerotic, not having a slit-shaped obturator foramen, lacking a posteriorly expanding pubis, and lacking a tubercle along the ventral margin just anterior to the pubis. This specimen compares reasonably well with Dusignathus seftoni, but has a slightly more robust ischium. UCMP 125572 is nearly identical to the innominate of cf. Pontolis magnus (True, 1905) (USNM 335571), although it is much smaller in size. It is not possible to make comparisons with Gomphotaria, as the innominata of Gomphotaria are unknown. The metatarsal is tentatively referred to the Dusignathinae based on its longer and slenderer shaft relative to the odobenines Odobenus and Valenictus; well-preserved metatarsals are not yet known for Dusignathus or Gomphotaria, and cf. Pontolis magnus (USNM 335571) preserves only metatarsal II, IV, and $\mathrm{V}$. This specimen has a shorter shaft than the metatarsal III of the basal odobenid Proneotherium (Deméré and Berta, 2001), which also has a less robust proximal end than UCMP 125576. It further differs from Valenictus in lacking a distally thickening shaft, and lacking a sharp tuberosity at the distal end of the ventral metatarsal II facet. UCMP 125576 further differs from Odobenus in having a smooth proximal shaft that lacks a sharp ridge along the ventromedial and ventrolateral edges of the shaft. The wide and distally tapering distal end of UCMP 125579 is similar to phalanges of Gomphotaria and Valenictus.

\author{
Genus Imagotaria Mitchell, 1968 \\ cf. Imagotaria \\ Plate 5, figures 1-3
} radius.

Referred Specimens - UCMP 125572, isolated left

Description-Radius - This specimen is relatively small (184 mm total length), and has completely fused distal and proximal epiphyses (plate 5, figs. 1-3). The diaphysis of the radius is transversely flattened, and the proximal end is robust, transversely flared (54 $\mathrm{mm}$ greatest diameter), and anteriorly extended. The proximal humeral articular surface is sinuous and concave, and the head sits atop a transversely and anteroposteriorly narrow neck (37.4 mm least width). A small, convex radial tuberosity is located on the medial side of the neck. Along the anterior margin of the diaphysis, a slight 'corner' occurs midway at the pronator teres process. Distal to the pronator teres process, the radius is greatly expanded anteroposteriorly (70 $\mathrm{mm}$ greatest distal width). The medial surface of the diaphysis is slightly concave, and the lateral surface is gently convex. A well-developed flange-like radial process occurs on the anterodistal margin; distal to the radial process is a distally extending projection with a small convexity for the supinator longus, and a small trench between it and the radial process. The distal end bears a concave articular surface for the scapholunar; this facet is oval-shaped and smooth, and curves anterodistally. The styloid process occurs as a small arcuate ridge along the anterior margin of the scapholunar facet.

Remarks - The distally expanded and projecting radial process identifies this specimen as an odobenid radius (Deméré, 1994a). UCMP 125572 differs from radii of odobenine (for example, Aivukus, Odobenus, Pliopedia, Valenictus) walruses in its generally smaller size, more strongly anteriorly bowed shaft, and greater anteroposterior expansion of the distal half of the element. The robust proportions are similar with dusignathine radii, such as a referred forelimb of Dusignathus santacruzensis (LACM 3011, referred by Repenning and Tedford, 1977), an isolated radius of Dusignathus seftoni (SDNHM 92134), and the holotype radius of Gomphotaria pugnax Barnes and Raschke (1991) (LACM 121508); however, UCMP 125572 differs in being transversely narrow as opposed to the inflated radii of dusignathines (Mitchell, 1962; Repenning and Tedford, 1977; Barnes and Raschke, 1991), as well as being substantially smaller. A radius is unknown for Pontolis magnus, but would have certainly been much larger as Pontolis is even more gigantic than Gomphotaria (Deméré, 1994a). This specimen instead compares best with the radius of Imagotaria downsi (Repenning and Tedford, 1977, plates 11, 13) and Titanotaria 
orangensis (Magallanes and others, 2018, figs. 12d,e); these taxa share with UCMP 125572 a similarly expanded distal half but is relatively transversely narrow in comparison to dusignathines. However, because UCMP 125572 is somewhat smaller and even more transversely flattened than Imagotaria downsi, and far smaller than Titanotaria orangensis, this specimen is more conservatively identified as cf. Imagotaria.

Imagotaria downsi Mitchell (1968) has been previously reported from the late Miocene Monterey, Santa Margarita, and Sisquoc formations of California (10-7 Ma; Mitchell, 1968; Barnes, 1971; Barnes and others, 1985; Repenning and Tedford, 1977). Geochronologically younger but undescribed occurrences of Imagotaria include a new species from the upper Miocene Empire Formation of Oregon (8.7-6.5 Ma; Deméré, 1994a; Prothero and others, 2001) and several isolated postcanine teeth (UCMP 138156, 219435, and 219683) of cf. Imagotaria from the basal bonebed of the Purisima Formation near Santa Cruz, California (6.9-5.6 Ma; Boessenecker, 2013, appendix). This record of cf. Imagotaria further supports Messinian survival of the stem odobenid Imagotaria.

Subfamily Dusignathinae Mitchell, 1968 Genus Dusignathus Kellogg, 1927

Dusignathus santacruzensis Kellogg, 1927

Plate 6, figures 1-5; plate 7, figures 1-3

Referred Specimens-UCMP 125571, fragment of right maxilla with c1; UCMP 125569, left mandible lacking teeth.

Description-Maxilla and Upper Dentition-UCMP 125571 is a fragment of the right maxilla with the c1 preserved from a relatively small individual, possibly representing a neonate or juvenile (plate 6, figs. 1-6). The lateral side of the maxilla is relatively flat and smooth. On the posterodorsal margin, the anterior part of the infraorbital foramen is preserved as a small arc-shaped excavation. The medial and dorsal surfaces are broken, including the anterodorsal wall of the $\mathrm{c} 1$ alveolus. The $\mathrm{c} 1$ is preserved in situ within a cavernous alveolus, and the $\mathrm{c} 1$ does not contact the sides of the alveolus, similar to extant juvenile pinnipeds. The canine is circular in cross section, relatively straight and slightly curving, and there is a small enamel crown with a posterior crista. The $\mathrm{c} 1$ crown apex does not reach the ventral margin of the maxilla. The pulp cavity of the $\mathrm{c} 1$ is open and large (but filled with matrix) and encircled by a thin cylindrical wall of dentine. Empty circular $\mathrm{p} 1$ and $\mathrm{p} 2$ alveoli are present on the ventral margin; the maxilla is broken at the level of the partially preserved p3 alveolus. The p2 and p3 alveoli extended far dorsally and are exposed dorsomedially and medial to the $\mathrm{c} 1$. Premolar alveoli are all cylindrical, indicating that the $\mathrm{p} 1-3$ had robust, cylindrical roots.

Mandible - This relatively small mandible (UCMP 125569) lacks teeth and is otherwise well preserved, except for slight damage to the coronoid process (plate 7). The horizontal ramus is tabular, with nearly parallel dorsal and ventral margins. The symphyseal surface is elongate and oval-shaped in medial aspect, and bears a slightly rugose surface texture.
The bone surface of the anterior end of the mandible and mandibular terminus is smooth. The symphyseal part of the mandible is slightly upturned, and the i2, i3, and c1 alveoli are positioned at the anterodorsal tip. In dorsal aspect, the symphyseal part of the mandible is transversely very narrow; the toothrow and horizontal ramus are widely divergent from the midline (approximately $15-20^{\circ}$ between the toothrow and sagittal plane). A poorly developed genial tuberosity is present at the posteroventral termination of the mandibular symphysis. The ventral margin of the mandible is sinuous due to the welldeveloped flange-like digastric insertion. The angular process is positioned on the ventral side of the ascending ramus; it is anteroposteriorly short, and developed into a robust medial shelf. A shallow masseteric fossa occurs on the lateral surface of the ascending ramus; medially, a posterodorsally opening mandibular foramen is present. The coronoid process is low and posterodorsally directed, and although broken, the posterior margin of the coronoid process appears to have been straight and vertical. The mandibular condyle is cylindrical and horizontally oriented.

Lower Dentition - Although no teeth are preserved in this specimen, the alveoli are well-preserved and indicate the position and root morphology of the dentition (plate 7, fig. 2). The i2 alveolus is small and oval in shape, and positioned adjacent to the symphyseal surface. A much larger i3 alveolus is circular and positioned posteromedial to the $\mathrm{i} 2$ alveolus. The c1 alveolus is large, oval shaped, and positioned posteriorly to the $i 3$ alveolus. Most of the postcanine alveoli are all oval in shape, with the exception of the circular p1 alveolus; it is also separated from the $\mathrm{cl}$ by a slight diastema. The postcanine toothrow only includes four alveoli; there is a large diastema between the third and fourth alveolus; this alveolus is wide enough to have included an additional fifth alveolus, and this is interpreted to be a pathologically closed $\mathrm{p} 4$ alveolus. The alveolus posterior to this and separated from the third alveolus is interpreted to be the $\mathrm{m} 1$, and the other three alveoli as the $\mathrm{p} 1-3$. The $\mathrm{p} 2$ alveolus is larger and oval in shape, and is separated from the $\mathrm{p} 1$ and $\mathrm{p} 3$ by small diastemata. The $\mathrm{p} 3$ alveolus is larger and also oval in shape, whereas the $\mathrm{m} 1$ alveolus is small and circular. The $\mathrm{p} 2$ and $\mathrm{p} 3$ alveoli are proportionally wide relative to the width of the ramus that there are triangular notches in the dorsal margin where mandibular bone was resorbed from around the roots of these teeth. All alveoli are single-rooted.

Remarks-These specimens compare best with Dusignathus santacruzensis. The sinuous ventral margin of the mandible indicates that this specimen is a dusignathine (Deméré 1994a). UCMP 125569 differs from Gomphotaria pugnax in having a relatively smaller diameter canine, a sinuous lower border of the mandible (Gomphotaria is the only dusignathine that lacks this feature), and in its smaller size. It differs from Pontolis magnus in its substantially smaller size, single-rooted $\mathrm{m} 1$ alveolus, proportionally more elongate mandibular symphysis, anteroposteriorly shorter coronoid process, and a less well-developed digastric process. 
UCMP 125569 also can be excluded from Dusignathus seftoni in its smaller size, lacking a fused mandibular symphysis, and having a linear postcanine toothrow (not arcuate as in D. seftoni). With some minor differences, this specimen compares best with the holotype mandible (UCMP 27121) of Dusignathus santacruzensis Kellogg (1927) and can be confidently referred to Dusignathus santacruzensis. Both of these specimens are relatively small in comparison to adult specimens of Dusignathus. The maxilla fragment is extremely small, and the canine is clearly interrupted and incompletely formed; it is likely that these are from a young juvenile or neonate. Because of the extremely small size of the upper canine in UCMP 125571, it is likely deciduous. The small size of the mandible and small diameter canine in comparison with the probable female holotype specimen (UCMP 27121) indicate that the mandible (UCMP 125569) likely represents a juvenile female. UCMP 125569 differs from the holotype of D. santacruzensis described from the Purisima Formation in Santa Cruz, Santa Cruz County, in possessing large incisor alveoli positioned anterior to the $\mathrm{c} 1$ alveolus, which according to Deméré (1994b), lacks lower incisors or alveoli. Like the holotype of D. santacruzensis, the incisor alveoli of UCMP 125569 are not positioned medial to the $\mathrm{c} 1$. However, in the holotype specimen the part of the mandible anterior to the $\mathrm{c} 1$ is broken and completely missing, thus illuminating the possibility that the holotype specimen possessed lower incisors prior to damage incurred during collection. Fossils of Dusignathus santacruzensis have been reported from the Purisima Formation of central California (Kellogg, 1927; Repenning and Tedford, 1977) and from the Almejas Formation of Baja California, Mexico (Repenning and Tedford, 1977). Additional specimens (UCMP 83370; Repenning and Tedford, 1977, p. 44, 47, plate 15, fig. 22) that were referred to $D$. santacruzensis by Repenning and Tedford (1977) from the Santa Margarita Sandstone at Point Reyes, Marin County, California, (same as Drakes Bay Formation of Galloway, 1977; Repenning and Tedford, 1977, p. 44 and 47 , plate 15 , fig. 22 ) are currently being reevaluated, and may represent a separate odobenid taxon (Boessenecker, 2007). Additionally, a partial odobenid forelimb (LACM 3011) described by Mitchell (1962) from the Purisima Formation also probably belongs to $D$. santacruzensis (Repenning and Tedford, 1977; Boessenecker, 2007). A second, geologically younger species, Dusignathus seftoni, was described by Deméré (1994b) from the San Diego Formation of southern California. A preliminary study by Boessenecker (2007) reported a partial forelimb of Dusignathus from the late Miocene St. George Formation near Crescent City, Del Norte County, California. In addition, Dusignathus santacruzensis is now described from the Wilson Grove Formation. This occurrence is unsurprising as all these formations (Purisima, St. George, and Wilson Grove Formations) are roughly the same age (equivalent with the Messinian Stage of international usage). Furthermore, owing for $130 \mathrm{~km}$ post-late Miocene San Andreas Fault offset, these occurrences suggest that
Dusignathus santacruzensis inhabited 1,450 km of the Pacific shoreline of North America during the latest Miocene.

Genus Gomphotaria Barnes and Raschke, 1991

Gomphotaria pugnax Barnes and Raschke, 1991 Plate 8 , figures $1-4$

Referred Specimens-UCMP 125570, a fragment of the anterior part of a large left mandible including the $\mathrm{c} 1$ and probable $\mathrm{p} 2$.

Description-Mandible - The anterior part of a mandible is preserved, and is broken at the $\mathrm{p} 3$ alveolus (plate 8). It includes the $i 3$ alveolus, the $\mathrm{c} 1$, the $\mathrm{p} 1$ alveolus (filled with bone), $\mathrm{p} 2$, and part of the $\mathrm{p} 3$ alveolus. The symphyseal surface is completely preserved, is oval in shape, and has a very rugose surface texture. There is missing bone on the symphyseal surface medial to the canine; a thin layer of matrix sits on this exposed medial surface of the canine where the bone would have been, and only a wafer-thin septum of bone could have been present between the canines. Although very fragmentary, the ramus appears to be posterolaterally oriented, but at a very low angle. The ramus is very wide and robust transversely. On the lateral surface, there are mental foramina below the $\mathrm{c} 1$ and $\mathrm{p} 1$ alveoli. Another large foramen is present along the anteroventral margin, separated medially from the symphyseal surface by a thin septum of bone.

Dentition - Only one incisor alveolus is present, and it is small, shallow (about $6 \mathrm{~mm}$ deep), and positioned anteromedial to the $\mathrm{c} 1$. It is unclear if this is the $\mathrm{i} 2$ or $\mathrm{i} 3$. The $\mathrm{c} 1$ is very large, robust, and parasagittally oriented. The apex of the crown is extremely worn into three wear facets (anterolateral, medial, and posterior). The canine is oval-shaped in cross section, and exhibits longitudinal striations. The canine is not curved laterally, and is slightly curved dorsally. There is a large diastema between the $\mathrm{c} 1$ and the anteriormost alveolus, and in between is a circular patch of bone with a slightly more cancellous texture. In modern pinnipeds (most often otariids), postcanine teeth are occasionally lost during life, and are filled in with cancellous bone, leaving a similar texture as in this specimen. Thus, this former alveolus is interpreted to be the $\mathrm{p} 1$. The $\mathrm{p} 2$ is still present in its alveolus, and is simple, peg-like, and appears to have a single, cylindrical root. The crown is completely abraded away, and the crown morphology is indiscernible. The tooth is oval in cross section, and is closely appressed with the $\mathrm{p} 1$ and $\mathrm{p} 2$ alveoli. The root of the $\mathrm{p} 2$ is visible anteriorly from the $\mathrm{p} 3$ alveolus where part of the interalveolar septum is missing. It is not clear if this was taphonomic, or if the teeth were so closely appressed that the interalveolar septum was remodeled away, as occurs in some extant pinnipeds. Only the anterior part of the $\mathrm{p} 3$ alveolus is preserved.

Remarks - This specimen shares several features in common with the holotype of Gomphotaria pugnax (LACM 121508), including a very large and procumbent $\mathrm{c} 1$ with longitudinal striations, a single-rooted $\mathrm{p} 2$, extreme wear of the dentition, and rugose surface texture of the mandibular 
terminus. As the mandible is well preserved and unabraded, the extreme tooth wear most likely occurred during life and is not a taphonomic feature. This specimen shares the most features in common with G. pugnax and is assigned to that species. Dusignathus santacruzensis also exhibits procumbent lower canines, but these are less robust and tusk-like and lack the longitudinal striations that characterize this specimen; the postcanine teeth of Dusignathus santacruzensis also only exhibit anterior and posterior wear facets. A recently collected mandible of $D$. seftoni (SDNHM 90507) exhibits highly worn tusk-like lower canines, but these are less procumbent, and the dentaries of $D$. seftoni are fused at the symphysis, unlike this specimen. Lastly, Pontolis magnus differs from this specimen in lacking procumbent lower incisors, lacking extreme wear on the postcanine teeth, and having a bilobate $\mathrm{p} 2$ root.

UCMP 125570 differs from the holotype of Gomphotaria pugnax in its narrower canine, smaller size, and more extreme wear of the canine. The extreme dental wear and rugose bone surface both suggest that this individual was mature, and the relatively smaller size and proportionally smaller canine suggest this may be a female; the holotype skeleton of G. pugnax (LACM 121508) has a baculum and is thus demonstrably a male (Barnes and Raschke, 1991). Gomphotaria has previously been described from the late Miocene to early Pliocene Capistrano Formation (Barnes and Raschke, 1991; Deméré, 1994b) and listed from the late Miocene to late Pliocene Purisima Formation (Deméré and others, 2003); the new specimen from the Purisima Formation has yet to be described. An apparently new plesiomorphic species of Gomphotaria from the late Miocene to early Pliocene Towsley Formation (Berkoff and Barnes, 1998) also awaits description. The Wilson Grove Formation specimen is the first specimen of Gomphotaria to be described from outside the Capistrano Formation, and extends the range of this taxon approximately $850 \mathrm{~km}$ north (adjusted for San Andreas Fault offset).

\section{cf. Pontolis}

Plate 9, figures 1-3

Referred Specimens-UCMP 81134, a large femur missing the head.

Description-Femur - The femur is very large, and relatively elongate ( $238.3 \mathrm{~mm}$ total length from condyle to greater trochanter; plate 9). The greater trochanter is partially preserved, and laterally convex. The lesser trochanter is small and convex, and situated below the preserved neck of the femur. The shaft of the femur broadens distally towards the large, convex, distal condyles (113.6 mm distal transverse width). A deep intercondylar furrow is present between the condyles. In anterior aspect, the distal margin of the femur is inclined so that the medial condyle is positioned slightly further distal than the lateral condyle. The anterior surface of the shaft is transversely convex, and distally a large, rectangular and slightly damaged patellar trochlea occurs.
Remarks-This specimen is most similar to femora of dusignathine odobenids, and can be directly compared with the dusignathines Dusignathus seftoni, Gomphotaria pugnax, and Pontolis magnus, the stem odobenid Imagotaria, Pliocene odobenines including Ontocetus emmonsi and Valenictus chulavistensis, and the extant walrus Odobenus rosmarus. Pontolis is represented by a partial skeleton of a gigantic individual (National Museum of Natural History, Smithsonian Institution, USNM, 335571, identified here as cf. Pontolis magnus) from the late Miocene Empire Formation in Oregon (Deméré, 1994a), the holotype specimen of which was collected from the same locality (Deméré, 1994a). Additional topotypic material of Pontolis magnus exists in the Douglas Emlong collection and awaits description. The Wilson Grove Formation specimen, UCMP 81134, differs from all known odobenids with the exception of cf. Pontolis magnus (USNM 335571) in possessing a relatively elongate femoral shaft and distal end that is not widely flared; all other odobenids exhibit relatively short femora with widely flaring distal ends. Dusignathus seftoni (SDNHM 77891) is similar in overall size but differs from UCMP 81134 in having a narrower shaft with an abruptly widening distal end; Imagotaria downsi (USNM 23870) differs from UCMP 81134 in being proportionally wider, and UCMP 81134 further differs from the toothless odobenine Valenictus chulavistensis in lacking an osteosclerotic femoral histology, and lacking an extremely inflated distal end. Gomphotaria pugnax exhibits an extremely robust and wide shaft, and is nearly twice as wide relative to UCMP 81134. Although slightly less robust and transversely narrower, UCMP 81134 is most similar to USNM 335571 (cf. Pontolis magnus) and is therefore tentatively assigned to the genus Pontolis.

\section{Subfamily Odobeninae Mitchell, 1968 \\ Odobeninae indeterminate \\ Plate 5, figures 4-5} metacarpal.

Description-Metacarpal-This specimen is a small (63.9 $\mathrm{mm}$ total length) and robust left metacarpal I lacking the proximal epiphysis (plate 5, figs. 4 and 5). It is proximally swollen and thick (16.34 $\mathrm{mm}$ proximal width) and tapers distally. It is slightly laterally curved.

Remarks-UCMP 125575 is similar to the metacarpal I of the odobenine walruses Aivukus, Pliopedia, Valenictus, and Odobenus in being proximally swollen. A single specimen of Valenictus chulavistensis with articulated forelimbs (SDNHM 83719) also possesses a similarly bowed and proximally inflated proximal manual phalanx on the first digit, although it is straight in Odobenus rosmarus. This specimen represents a first metacarpal as it possesses a convex distal trochlea, unlike the saddle-shaped trochlea in the proximal phalanx of SDNHM 83719. It differs from the metacarpal I of Imagotaria and Dusignathus in lacking a straight, narrow shaft. UCMP 
125575 differs from Pliopedia in having a more swollen shaft, but shares the lateral curvature. This specimen shares a swollen shaft with Aivukus, Valenictus, and Odobenus and differs from Aivukus in having a more laterally curved shaft; it is most similar to Odobenus and Valenictus, and is referred to the Odobeninae.

Order Cetacea Brisson, 1762

Suborder Odontoceti Flower, 1869

Odontoceti indeterminate

Plate 10, figures 1-6

Referred Specimens-UCMP 125585, tooth; 125586, atlas; UCMP 125587-8, vertebrae.

Description and Remarks - The isolated tooth is very small, with a conical crown, and a cylindrical root (plate 10, figs. 1-3). The tooth is posteriorly curved. The partial atlas and vertebrae are of typical odontocete morphology (plate 10, figs. 4-6). Because teeth and vertebrae are generally not diagnostic for cetaceans (Barnes, 1976 [1977]), it is not possible to further identify these specimens.

Suborder Mysticeti Flower, 1864

Family Balaenopteridae Gray, 1864

Balaenopteridae indeterminate

Plate 11, figures 1-6, 9-10

Referred Specimens-UCMP 125833, a fragmentary left mandible including the anterior part and a fragment of the posterior part of the mandible.

Description and Remarks-UCMP 125833 consists of two fragments of a poorly preserved left mandible (plate 11, figs. 1-4). The posterior fragment preserves a part of the mandible near the coronoid process, but anterior to the mandibular foramen opening and the coronoid process. The mandibular foramen is large in cross section. Posteriorly, the mandible fragment is transversely narrow, and planar medially and slightly convex laterally. Dorsally, there is a very high precoronoid crest that becomes gradually higher posteriorly. Anteriorly, the medial and lateral surfaces are much more convex. The anterior part of a mandible is very transversely thin, although this may be due in part to diagenetic compaction as it exhibits obvious crushing. The anterior tip is missing and damaged. The anterior mandible transversely tapers anteriorly, and is bowed slightly laterally. The lateral surface is gently convex, and the medial surface is nearly flat. No ligamental groove on the anteromedial surface is preserved.

Although very fragmentary, some comparisons can be made of this specimen. UCMP 125833 is most similar to balaenopterid mysticetes in its morphology, and differs from eschrichtiids (gray whales) in having such a high anterior coronoid crest and having less convex medial and lateral surfaces anterior. UCMP 125833 differs from balaenids (right whales) in lacking a sharp ventral crest, and in having a well-developed, sharp anterior coronoid crest, and in being transversely narrow anteriorly. Additionally, UCMP 125833 is not an archaic mysticete, as the only known archaic mysticetes from the late Miocene of the eastern North Pacific are the herpetocetine cetotheriids such as Nannocetus and Herpetocetus, which have dentaries that are substantially smaller than the Wilson Grove Formation specimen (Boessenecker, 2011). This specimen, however, differs from all extant balaenopterids (Balaenoptera spp. and Megaptera novaeangliae) in having a mandible that is far more transversely narrow anterior and posterior, and has a much higher anterior coronoid crest. The coronoid crest of UCMP 125833 is similar to that of the extinct balaenopterid Parabalaenoptera baulinensis (Zeigler and others, 1997), which has an unusually tall and elongate crest on the dorsal surface of the mandible, which increases in height posteriorly, and has a posterior mandible that is unusually transversely narrow for a balaenopterid. Parabalaenoptera was first described from the contemporaneous Santa Cruz Mudstone near Bolinas in Marin County, California. However, because this specimen is so incomplete, it is not possible to assign this specimen to a genus. In addition, a partial cervical vertebra (UCMP uncatalogued), two well-preserved vertebral epiphyses (UCMP 125597 and 125598), and a phalanx (UCMP 125596) representing indeterminate large mysticetes (plate 11, figs. 5, 6, 9, and 10) were collected from Bloomfield Quarry, which may also belong to a balaenopterid. However, postcranial elements are generally not diagnostic among cetaceans (Barnes, 1976 [1977]).

Family Cetotheriidae Brandt, 1872

Subfamily Herpetocetinae Whitmore and Barnes, 2008 Herpetocetinae indeterminate Plate 11, figures 7-8

Referred Specimens - UCMP uncatalogued, a partial supraorbital process of the frontal bone.

Description and Remarks - This specimen is the anterior half of a small supraorbital process of the frontal, and the anteromedial and posterior parts are broken away (plate 11, figs. 7 and 8). Dorsally, it is relatively flat, and the antorbital process is slightly knoblike. The lateral margin of the supraorbital process continues posteromedially, and forms the anterior part of the laterally concave orbital margin. The dorsal surface slopes evenly laterally. Ventrally, there is a broadly convex ridge anteriorly. Posterior to this is a gentle concave surface that forms the dorsal roof of the orbit, and would have been medially confluent with the optic canal. This small supraorbital process is very similar to that of the herpetocetine mysticetes Herpetocetus and Piscobalaena (Bouetel and Muizon, 2006; Whitmore and Barnes, 2008); unfortunately, the Tortonian herpetocetine Nannocetus is not known from a complete frontal, and comparison is not possible. However, due to its similarity with Herpetocetus, this specimen is referred to the Herpetocetinae. 


\author{
Order Sirenia Illiger, 1811 \\ Family Dugongidae Gray, 1821 \\ Subfamily Hydrodamalinae Palmer, 1895 \\ Hydrodamalinae indeterminate \\ Plate 12, figures $1-6$
}

\section{Referred Specimens-UCMP 125594 and 125595, rib fragments. \\ Description and Remarks - These fragmentary ribs} (plate 12) are robust and composed of dense bone, and almost completely lack a medullary cavity (plate 12 , figs. 1-3). UCMP 125594 and 125595 are oval in cross section, and relatively more inflated than cetacean ribs. These rib fragments are pachyosteosclerotic, a condition that characterizes sirenians (manatees and sea cows). Only two taxa of sea cows are known from the late Miocene of the eastern North Pacific, the hydrodamalines Dusisiren spp. and Hydrodamalis cuestae (Domning 1978; Domning and Deméré 1984). Dusisiren is relatively smaller than the gigantic Hydrodamalis (Domning 1978), and these ribs are so small that they could be from a juvenile of either taxon, and thus can only be identified to the Hydrodamalinae.

\section{Discussion}

Barnes (1976 [1977]) reported the first marine mammals from the Wilson Grove Formation, including the lipotid dolphin Parapontoporia sternbergi and the balaenid right whale Balaenula sp. However, these specimens have not yet been described. To that list can be added cf. Imagotaria, Dusignathus santacruzensis, cf. Dusignathus, Gomphotaria pugnax, an indeterminate odobenine walrus, an indeterminate odontocete, an indeterminate balaenopterid whale, an indeterminate herpetocetine whale, and an indeterminate hydrodamaline sirenian. The marine mammal assemblage from Bloomfield Quarry represents the most diverse walrus assemblage yet reported worldwide. It includes a stem odobenid (cf. Imagotaria), three dusignathine walruses (Dusignathus santacruzensis, Gomphotaria pugnax, and cf. Pontolis), and an indeterminate odobenine walrus. The cetacean fossils are less diagnostic, and only indicate the presence of indeterminate odontocetes and mysticetes; more diagnostic cetacean material awaiting formal description includes skulls, mandibles, and petrosals from other localities in the Wilson Grove Formation, including a dwarf mysticete cranium (likely a herpetocetine) a few kilometers to the east (Allen and others, 1999; Powell and others, 2004, fig. 9), a skull of the extinct right whale Balaenula, and a mandible of the lipotid "river dolphin" Parapontoporia (Barnes, 1976 [1977]). Notably lacking from the marine mammal assemblage are otariid fur seals. Otariids are known from other late Miocene strata such as the Purisima Formation in central California (Repenning and Tedford, 1977), as well as localities stratigraphically higher in the Wilson Grove Formation. Again, these other specimens from the Wilson Grove Formation have yet to be described.
The pinniped assemblage is otherwise similar to that of the basal Purisima Formation near Santa Cruz, where Imagotaria, Gomphotaria and Dusignathus are preserved, alongside odobenine walruses and otariid fur seals (Mitchell, 1962; Boessenecker, 2013, appendix). Furthermore, Pontolis and Imagotaria are already known to co-occur within the Empire Formation of Oregon (Deméré, 1994a) and the Monterey Formation of Orange County (Barnes and others, 1985) and both Pontolis and Gomphotaria have been reported from the Capistrano Formation (Mitchell, 1968; Barnes and Raschke, 1991). Other multispecies walrus assemblages include the uppermost Miocene Almejas Formation of Baja California, Mexico (Aivukus cedrosensis and Dusignathus santacruzensis; Repenning and Tedford, 1977) and the Pliocene San Diego Formation of southern California (Dusignathus seftoni, Valenictus chulavistensis, and Odobeninae indeterminate; Deméré, 1994b; Boessenecker, 2013, p. 904). With five identified odobenids, the Wilson Grove Formation represents an unusually diverse assemblage of walruses.

\section{Birds by N. Adam Smith}

Materials and Methods - In the avian anatomical descriptions, the English equivalents of the Latin osteological nomenclature summarized by Baumel and Witmer (1993) are used. The terminology of Howard (1929) is followed for features not treated by Baumel and Witmer (1993). With the exception of the terms anterior and posterior substituted for cranial and caudal, respectively, the terms used for the anatomical orientation of a bird are those used by Clark (1993). Measurements follow those of von den Driesch (1976). All measurements were taken using digital calipers and rounded to the nearest tenth of a millimeter. Comparisons with extinct taxa were made through direct observation of type and referred specimens. Extant comparative skeletal material is listed below.

Extant Comparative Skeletal Material-Aethia cristatella Crested Auklet (NCSM 17749 and USNM 223707, 488675, 498282, 561934, 61094); Alca torda Razorbill Auk (NCSM 20058, 20502 and USNM 18062, 347946, 501644, 502378, 502382, 502387, 502388, 502389, 502549, 555666, 555668); Alle alle Dovekie (NCSM 18374 and USNM 344740, 344748, 499471, 560929); Brachyramphus perdix Long-billed Murrelet (USNM 582506, 599498); Cepphus columba Pigeon Guillemot (NCSM 18094, 18095, 18096, 18097 and USNM 610936); Fratercula arctica Atlantic Puffin (USNM 18055, 18057, 18058, 224189, 621331); Pinguinus impennis Great Auk (USNM 346387 (composite), 557975 (composite), 623465 (composite); Uria aalge Common Murre (NCSM 17822, 18116, 18117, 18118, 18234); Uria lomvia Thick-billed Murre (NCSM 18114, 19414 and USNM 344435, 561265); Synthliboramphus hypoleucus Xantus' Murrelet (USNM 19387, 291879, 345427, 345428, 500652). 
Class Aves Linnaeus, 1758

Aves indeterminate

Referred Specimens-UCMP 128208, distal end of right tibiotarsus (plate 13, figs. 1 and 2).

Description-Morphology and position of ossified supratendinal bridge and medial epicondylar depression of UCMP 128208 consistent with that of Pan-Alcidae.

Remarks-No apomorphies are preserved that would allow for precise referral of this specimen within Aves.

\author{
Order Charadriiformes Huxley, 1867 \\ Clade Pan-Alcidae Smith, 2011 \\ Pan-Alcidae indeterminate \\ Plate 13, figures 3-6
}

Referred Specimens-UCMP 128209, proximal part of right ulnar shaft fragment (plate 13, figs. 3 and 4); UCMP 128210, two fragments of left humeral shaft (plate 13, figs. 5 and 6).

Description-The dorsoventral compression of these fragments of pectoral limb shaft supports referral to PanAlcidae. A distinct groove, possibly the $\mathrm{m}$. brachialis fossa, is visible along the anterior margin of UCMP 128209 (plate 13, figs. 3 and 4). However, no feather papillae are visible on the preserved part of shaft.

A part of the deltopectoral crest is preserved along the dorsal margin of the two humeral shaft fragments (UCMP 128210; plate 13, figs. 5 and 6). Based on the size and crosssectional profile, these specimens likely represent the mid-shaft of the humerus. Distal extension of the deltopectoral crest past the mid-shaft is an apomorphy of Mancallinae and these specimens likely represent that taxon.

Remarks-No additional apomorphies or diagnostic characteristics are preserved that would allow for more precise referral of these three specimens.

\section{Clade Mancallinae Brodkorb, 1967 Mancallinae indeterminate Plate 14}

\section{(plate 14).}

Referred Specimens-UCMP 128207, right coracoid

Description-UCMP 128207 is missing a fragment of bone along the lateral margin of the sternal end where the lateral process would likely have been, but is otherwise complete (plate 14). The shaft of the coracoid omal to the procoracoid process is relatively straight as in Fraterculinae (that is, Aethia, Ptychoramphus, Cerorhinca, and Fratercula) and other Mancallinae (that is, the clade comprising Mancalla+Miomancalla), rather than curved as in Alcinae (that is, Alca, Pinguinus, Uria, Alle, Miocepphus, Cepphus, Brachyramphus, and Synthliboramphus; fig. 4). As in all known Mancallinae, the procoracoid process is triangular and lacks an nervus supracoracoideus foramen. The procoracoid process of Cerorhinca, and Fratercula (that is, Fraterculini) is fenestrated and the procoracoid process of Aethia and Ptychoramphus (that is, Aethiini; fig. 4) is rectangular (Smith, 2013b). The furcular facet is rounded rather than oval as in Mancalla californiensis Lucas (1901), and the supracoracoideus scar is less distinct than in Mancalla californiensis. As in all other Mancallinae, the sternal facet is angled $\sim 135^{\circ}$ in sternal view. This angle is more acute in all other Pan-Alcidae (Smith, 2011).

Remarks - Mancallinae coracoids are known only for Mancalla vegrandis Smith (2011), Mancalla californiensis Lucas (1901), and Mancalla cedrosensis Howard 1971 (Smith, 2011). Although UCMP 128207 can be differentiated from the only coracoid referred to Mancalla californiensis (LACM 15410), there are no morphological characters that differentiate this specimen from the holotype coracoids of Mancalla cedrosensis or Mancalla vegrandis. However, the greatest length of UCMP $128207(62.7 \mathrm{~mm})$ is considerably greater ( $\sim 27$ percent) than that of Mancalla cedrosensis ( $45.6 \mathrm{~mm}$ ) and Mancalla vegrandis $(45.8 \mathrm{~mm})$. This large difference in size is outside the range of intraspecific variation calculated for extant Alcidae (Smith and Clarke, 2011) and suggests that this coracoid is not referable to either of those species. Among Mancalla, only M. cedrosensis is known from the Miocene (that is, all other Mancalla species are Pliocene or younger), suggesting that UCMP 128207 may be representative of the relatively large, Miocene Mancallinae species, Miomancalla wetmorei (Howard 1976) or M. howardae Smith (2011), for which coracoids are not presently known.

\author{
Tribe Alcini Storer, 1960 \\ Genus Uria Pontoppidan, 1763 \\ cf. Uria brodkorbi Howard, 1981
}

Plate 15

Referred Specimens-UCMP 128206, proximal end of right humerus (plate 15).

Description-UCMP 128206 is broken distal to the junction of the bicipital crest with the humeral shaft (plate 15). The preserved part of shaft displays the dorsoventral compression characteristic of all Pan-Alcidae. The medial projection and roundness of the humeral head and the strong anteroventral curvature of the deltopectoral crest agree with that of previously documented Uria species. Although damaged, the posterior margin of the humeral head appears to be triangular like that of Uria rather than rounded as in Mancallinae and many other species of Alcinae (for example, Alca torda, Synthliboramphus hypoleucus, Brachyramphus perdix). As in all crown clade Alcidae, the head of the humerus is inline with the humeral shaft rather than anteriorly rotated as in Mancallinae (Smith, 2011). The junction between the bicipital crest and the humeral shaft is not notched as in Cepphus and Miocepphus, and the angle between the bicipital crest and the humeral shaft is not perpendicular as in Pinguinus, Alle, and Fraterculini. The musculus supracoracoideus scar on the posterior side of the humerus does not broaden proximally as in Fraterculini, Cepphus, and Miomancalla. As in all PanAlcidae, the primary pneumotricipital fossa is not deeply pneumatized (that is, pneumatic foramen absent). The depth 
of the primary pneumotricipital fossa (that is, ventral fossa) is consistent with that of Uria (that is, deeper than that of Pinguinus, Alca, Cerorhinca, and Mancallinae). As in all Alcinae, the secondary pneumotricipital fossa (that is, dorsal fossa) is not pneumatized (Smith, 2011). Fine-scale morphological details of the ventral tubercle are not discernible owing to weathering. The dorsolateral orientation and width of the capital groove are consistent with that of Uria, and the passage of nervus coracobrachialis on the anterior humeral surface appears to be in a sulcus like that of Uria rather than an enclosed bony canal as in Alca (Smith and Clarke, 2011).

Remarks-Other Alcinae known from the Miocene of the Pacific Ocean basin are limited to Uria brodkorbi Howard (1981), U. paleohesperis Howard (1982), and Cepphus olsoni Howard (1982) (Olson, 1985). UCMP 128206 is not referable to Cepphus (see description above), and Uria paleohesperis is likely a junior synonym of $U$. brodkorbi (Smith and Clarke, 2011). A poorly preserved specimen (proximal end of humerus; LACM 52018) from the Miocene "Monterey" Formation (not equivalent to the type Monterey Formation in Monterey County) of Orange County, California, was tentatively referred to Uria by Howard (1978). Additional Uria remains have not been reported from that location (N.A. Smith, unpublished data, 2018). Uria brodkorbi is known from a single well-preserved associated partial skeleton (UF/PB $7960 \mathrm{~A}$ and B) from the late Miocene to early Pliocene Sisquoc Formation of Santa Barbara County, California (Howard, 1981). The age of Uria brodkorbi is consistent with the late Miocene (>6.25 Ma) age assigned to the basal unit of the Wilson Grove Formation (Sarna-Wojcicki, 1992; Powell and others, 2004). The greatest width of the proximal humerus of Uria brodkorbi (18.2 $\mathrm{mm}$ ) is also consistent with that dimension in UCMP 128206 (19.0 mm). Although UCMP 128206 does not preserve sufficient morphological detail to be unambiguously referred to Uria brodkorbi, the possibility that this specimen represents that species should be considered on recovery of additional remains of this taxon from the Wilson Grove Formation.

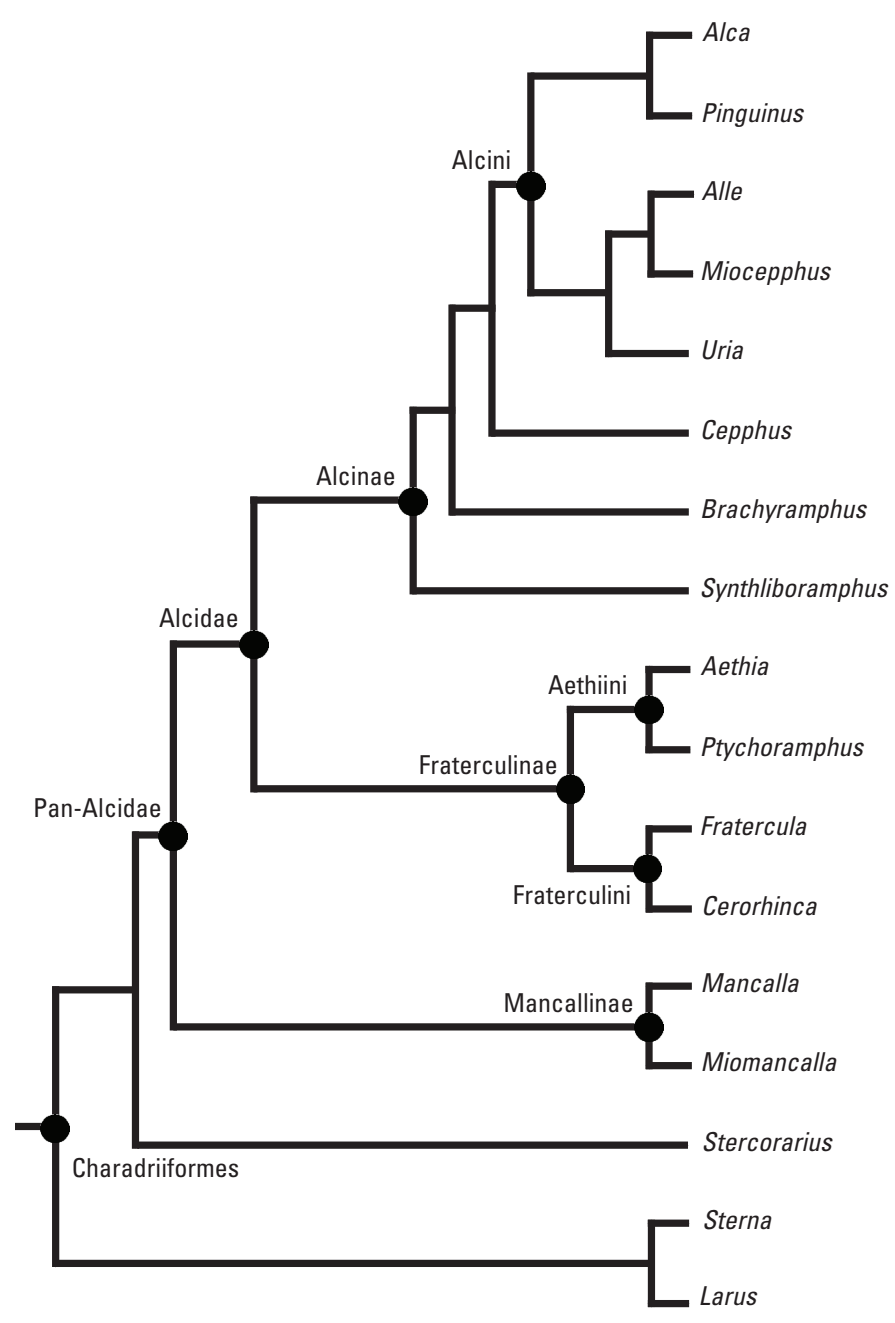

Figure 4. Cladogram depicting pan-alcid relations (topology based on Smith, 2011, fig. 15; Smith and Clarke, 2011, fig. 6). 


\section{Plates 1-15}

[Institutional abbreviations - CAS, California Academy of Sciences; NCSM, North Carolina Museum of Natural Sciences; LACM, Natural History Museum of Los Angeles County; SDNHM, San Diego Natural History Museum; UCMP, University of California Museum of Paleontology; USNM, National Museum of Natural History, Smithsonian Institution] 


\section{Plate 1}

Selected brachiopod fossils from the basal Wilson Grove Formation exposed in Bloomfield Quarry, just north of the town of Bloomfield in Sonoma County, California. mm, millimeter. (Photographs by Sandy Carlson, University of California, Davis, and Christine Garcia, California Academy of Sciences.)

Figures 1. Discinisca cf. D. cumingii (Broderip, 1833). Dorsal valve exterior. CAS locality 54136. CAS hypotype 78201. Maximum length $21 \mathrm{~mm}$, maximum width $20 \mathrm{~mm}$. Vaguely reticulate ornament visible.

2-4. Terebratulina cf. T. unguicula (Carpenter, 1864). Dorsal valve. CAS locality 54135. CAS hypotype 78202. Maximum length $12 \mathrm{~mm}$, maximum width $15 \mathrm{~mm}$. 2, Interior; 3, exterior with delicate radial ribbing; 4, posterior view of cardinal process and broken cardinalia.

5-6. Terebratalia cf. T. occidentalis Dall (1891). Articulated specimen. CAS locality 54136. CAS hypotype 78204. Maximum length $27 \mathrm{~mm}$, maximum width $24 \mathrm{~mm}$, maximum depth $16 \mathrm{~mm}$. 5, Lateral view, ventral valve on left; 6 , ventral valve exterior.

7, 9. Terebratalia cf. T. occidentalis Dall (1891). Articulated specimen. CAS locality 54135. CAS hypotype 78205. Maximum length $25 \mathrm{~mm}$, maximum width $22 \mathrm{~mm}$, maximum depth $14 \mathrm{~mm}$. 7, Dorsal view, dorsal valve exterior with broad and weakly developed radial ornament; 9, anterior commissure view, ventral valve below, with ventral sulcus clearly demarcated.

8, 10. Terebratalia cf. T. transversa (Sowerby, 1846). CAS locality 54135. 8, CAS hypotype 78206, dorsal valve interior, maximum length $22 \mathrm{~mm}$, maximum width $34 \mathrm{~mm}$, wide cardinal process and low median septum visible. 10, CAS hypotype 78207, ventral valve interior, maximum length $22 \mathrm{~mm}$, maximum width $27 \mathrm{~mm}$. Large pedicle foramen and broad palintrope clearly visible, as is valve asymmetry most likely due to crowding of individuals attached to hard substrate. 

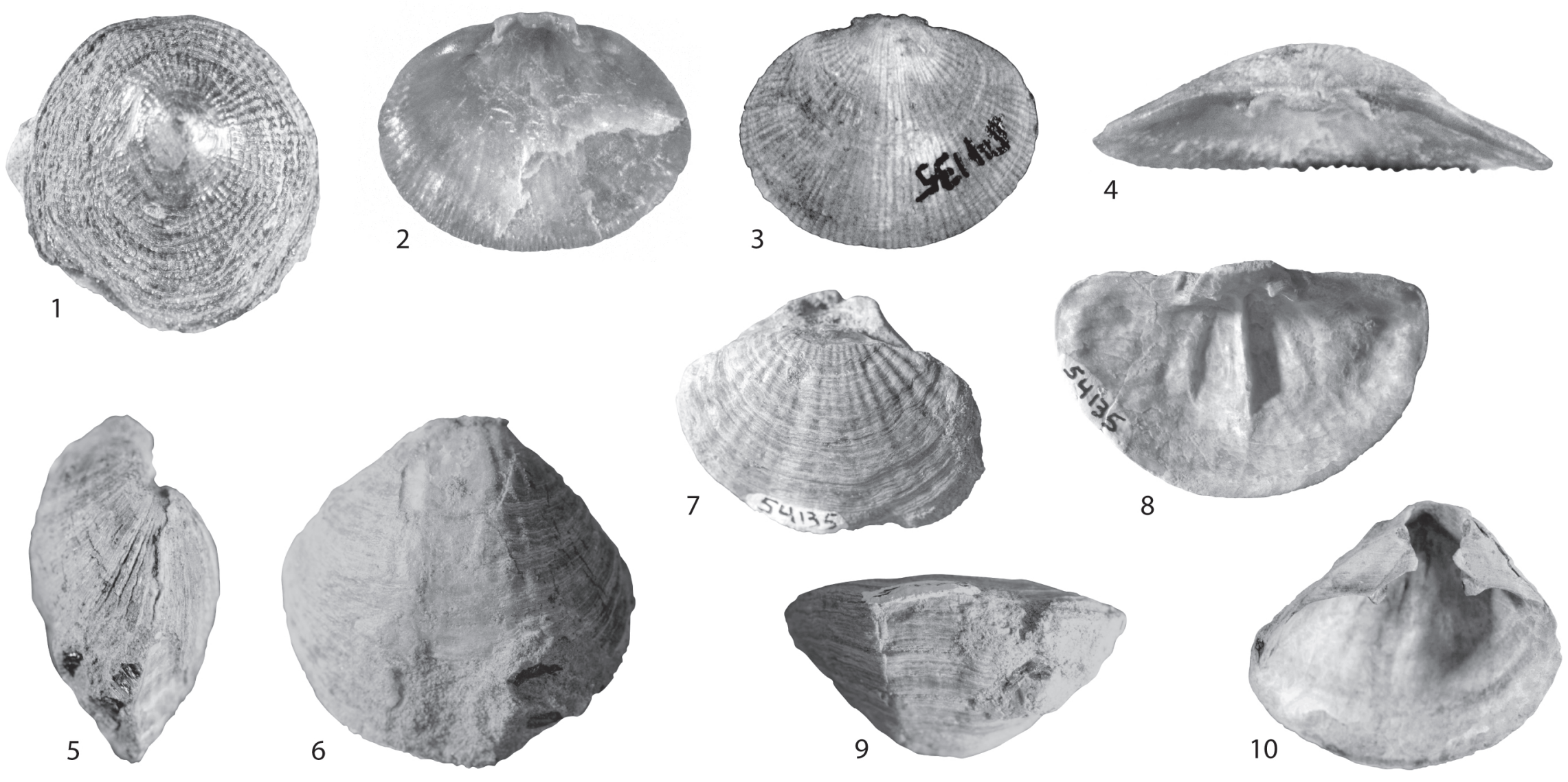

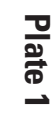




\section{Plate 2}

Selected mollusk fossils from the basal Wilson Grove Formation exposed in Bloomfield Quarry, just north of the town of Bloomfield in Sonoma County, California. mm, millimeter. (U.S. Geological Survey photographs by Charles Powell II.)

Figures 1, 4-6. Yoldia sp. indeterminate. CAS locality 54135. 1, 5, CAS hypotype 78401. Length $22.4 \mathrm{~mm}$, height $11.9 \mathrm{~mm}$. 4, 6, CAS hypotype 78402. Length $20.6 \mathrm{~mm}$, height $10.5 \mathrm{~mm}$.

2, 3. Arca santamariensis Reinhart (1937). CAS locality 54135. 2, CAS hypotype 78403. Length 55.4 $\mathrm{mm}$, height $32.6 \mathrm{~mm}$. 3, CAS hypotype 78404 . Length $45.6 \mathrm{~mm}$, height $30.4 \mathrm{~mm}$.

7, 15. Pododesmus cf. P. macrochisma (Deshayes, 1839). CAS locality 54135. 7, CAS hypotype 78426. Length $56.2 \mathrm{~mm}$, height $55.8 \mathrm{~mm}$. 15, CAS hypotype 78429. Length $24.8 \mathrm{~mm}$, width $17.1 \mathrm{~mm}$.

8, 9. Swiftopecten parmeleei (Dall, 1898). CAS locality 54135. 8, CAS hypotype 78405. Length 38.2 $\mathrm{mm}$, height $43.1 \mathrm{~mm}$. 9, CAS hypotype 78406. Length $27.2 \mathrm{~mm}$, height $33.5 \mathrm{~mm}$.

10. Anomia peruviana d'Orbigny (1846). CAS locality 54135. CAS hypotype 78427. Length $29.4 \mathrm{~mm}$, height $30.9 \mathrm{~mm}$.

11. Chlamys hodgei (Hertlein, 1925). CAS locality 54135. CAS hypotype 78428. Length $64.2 \mathrm{~mm}$, height $66.0 \mathrm{~mm}$.

12, 13. Chlamys aff. C. egregius (Nomland, 1917). CAS locality 54135. 12, Right valve. CAS hypotype 78407. Length $29.2 \mathrm{~mm}$, height $32.3 \mathrm{~mm}$. 13, Left valve. CAS hypotype 78408. Length $24.5 \mathrm{~mm}$, height $32.5 \mathrm{~mm}$.

14. Chlamys cf. C. hastata (Sowerby, 1842). Right valve. CAS locality 54136. CAS hypotype 78409. Length $67.3 \mathrm{~mm}$, height $75.4 \mathrm{~mm}$.

16. Crenomytilus cf. C. coalingensis (Arnold, 1909). CAS locality 54135. CAS hypotype 78410. Length $189 \mathrm{~mm}$, height $109 \mathrm{~mm}$. 
Plate 2

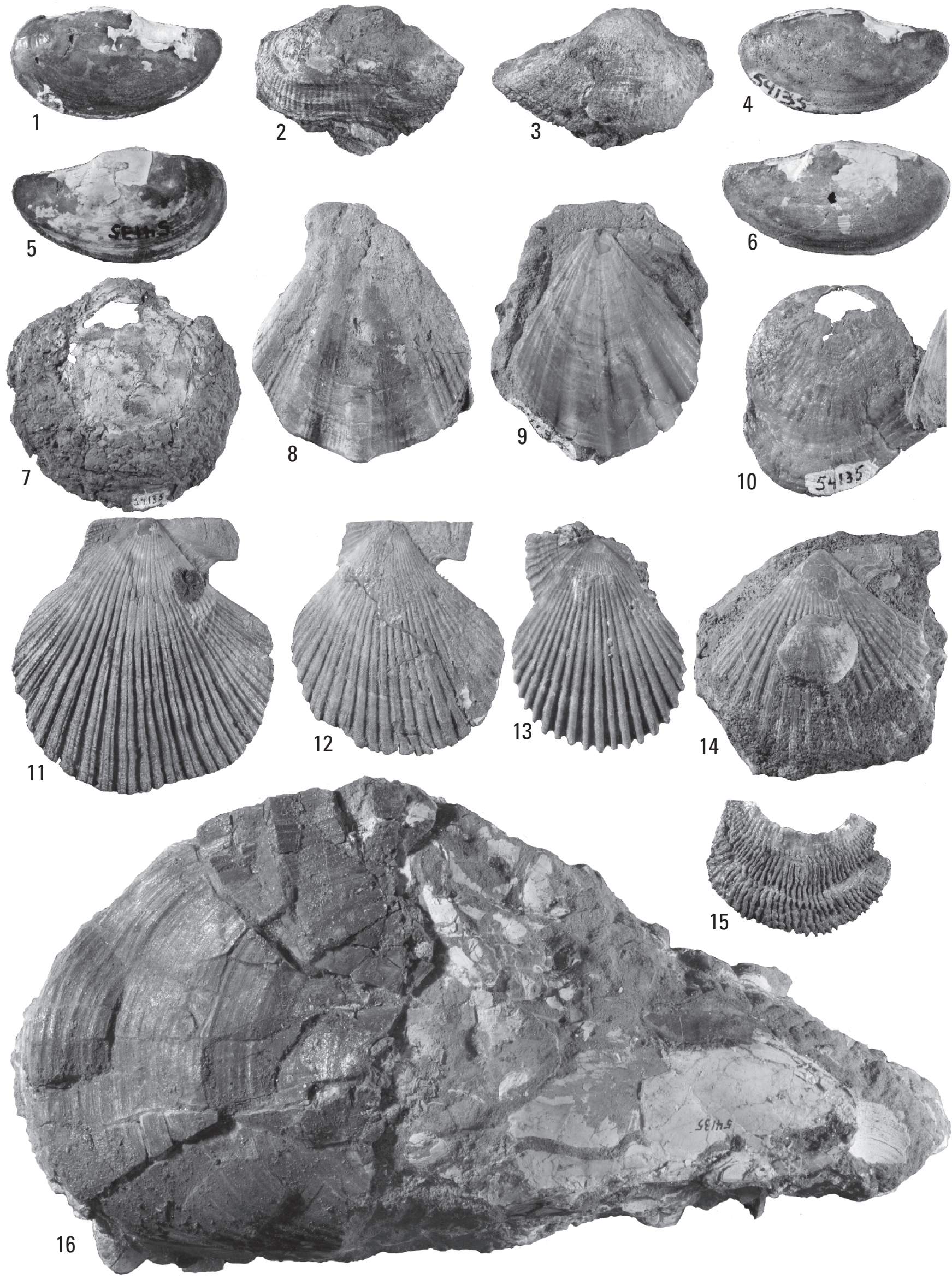




\section{Plate 3}

Selected mollusk fossils from the basal Wilson Grove Formation exposed in Bloomfield Quarry, just north of the town of Bloomfield in Sonoma County, California. mm, millimeter. (U.S. Geological Survey photographs by Charles Powell II.)

Figures
1. Macoma aff. M. indentata s.s. Carpenter (1864). Left valve. CAS locality 54135, CAS hypotype 78411. Length $42.5 \mathrm{~mm}$, height $32.7 \mathrm{~mm}$.

2, 3. Macoma sp. indeterminate. CAS locality 54135, CAS hypotype 78412. Length $38.2 \mathrm{~mm}$, height 32.9 mm. 2, Left valve; 3 , right valve.

4. Ensis sp. indeterminate. CAS locality 54135. Incomplete pair of valves. CAS hypotype 78413. Lower, right valve: height $17.9 \mathrm{~mm}$, width $41.2 \mathrm{~mm}$.

5, 7. Tresus pajaroanus (Conrad, 1857). CAS locality 54136. CAS hypotype 78414, Length 64.6 mm, height 47.6 mm. 5, Left valve. 7, Right valve.

6. Cardiidae indeterminate. Right valve. CAS locality 54135. CAS hypotype 78415. Length 53.4 $\mathrm{mm}$, height $52.8 \mathrm{~mm}$.

8. Crepidula princeps (Conrad, 1856 [1857]). Apical view, internal mold. CAS locality 54135. CAS hypotype 78416. Height 63.0, width 65.9.

9, 10. Nucella n. sp. CAS locality 54136. CAS hypotype 73156 . Height $33.4 \mathrm{~mm}$, width 19.5 mm. 9, Adapertural view; 10, apertural view.

11. Trochita cf. T. diabloensis (Clark, 1915). Apical view, latex cast. CAS locality 54135. CAS hypotype 78417, Height $46 \mathrm{~mm}$, greatest width $47.9 \mathrm{~mm}$. 
Plate 353
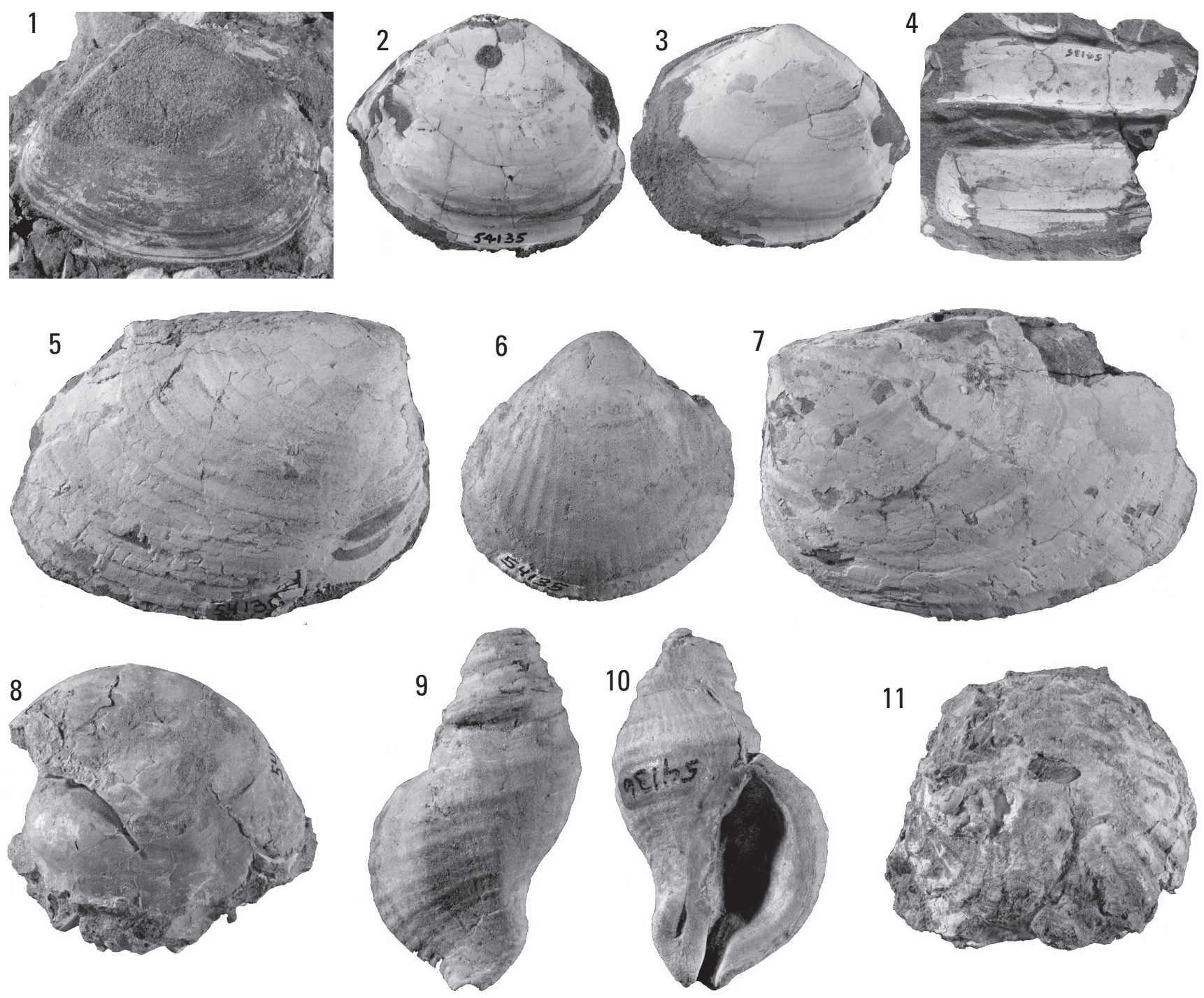


\section{Plate 4}

Selected fish fossils from the basal Wilson Grove Formation exposed in Bloomfield Quarry, just north of the town of Bloomfield in Sonoma County, California. mm, millimeter. (Photographs by Douglas Long, Saint Mary's College.)

Figures 1. Hexanchus griseus (Bonnaterre, 1788) upper anterior tooth. UCMP 125599.

2. Hexanchus griseus (Bonnaterre, 1788) lower lateral tooth. UCMP 1256000.

3. Isurus oxyrinchus Rafinesque (1810) lateral tooth. UCMP 125605.

4. Stereolepis sp. indeterminate. Vertebra anterior and lateral views of vertebra. UCMP 125612. 

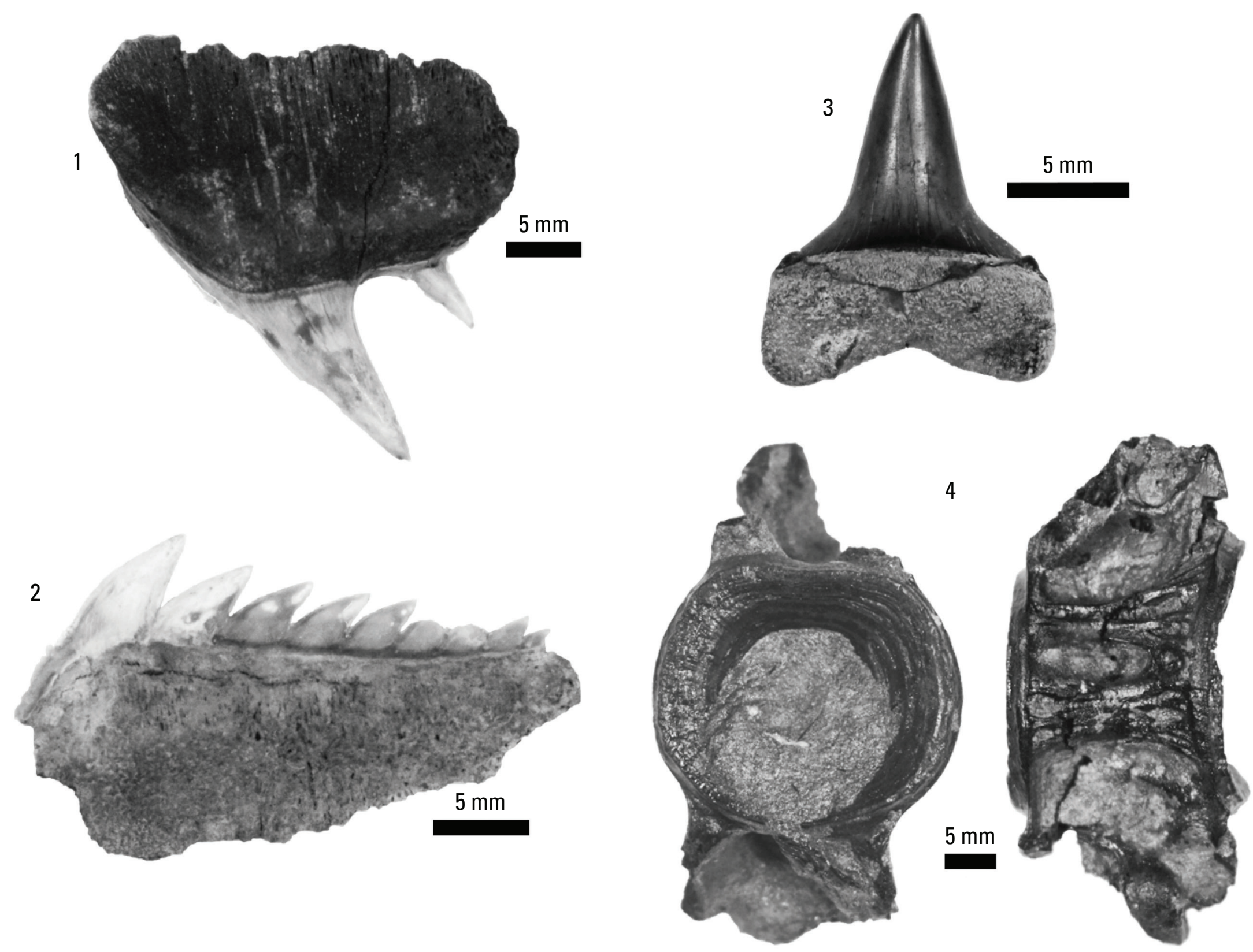


\section{Plate 5}

Walrus (Odobenidae) postcrania from the basal Wilson Grove Formation exposed in Bloomfield Quarry, just north of the town of Bloomfield in Sonoma County, California. cm, centimeter. (Photographs by Robert Boessenecker, College of Charleston.)

Figures 1-3. Imagotaria sp. indeterminate. Left radius. UCMP 125572. 1, Lateral view; 2, anterior view; 3, medial view.

4, 5. Odobeninae indeterminate. Left metacarpal 1. UCMP 125575. 4, Dorsal view; 5, ventral view.

6, 7. Odobenidae indeterminate. Distal phalanx. UCMP 125579. 6, Dorsal view; 7, ventral view.

8-11. Odobenidae indeterminate. Left third metatarsal. UCMP 125576. 8, Ventral view; 9, medial view; 10, dorsal view; 11, lateral view.

12, 13. Odobenidae indeterminate. Right innominate. UCMP 125574. 12, Medial view; 13, lateral view. 
Plate 5
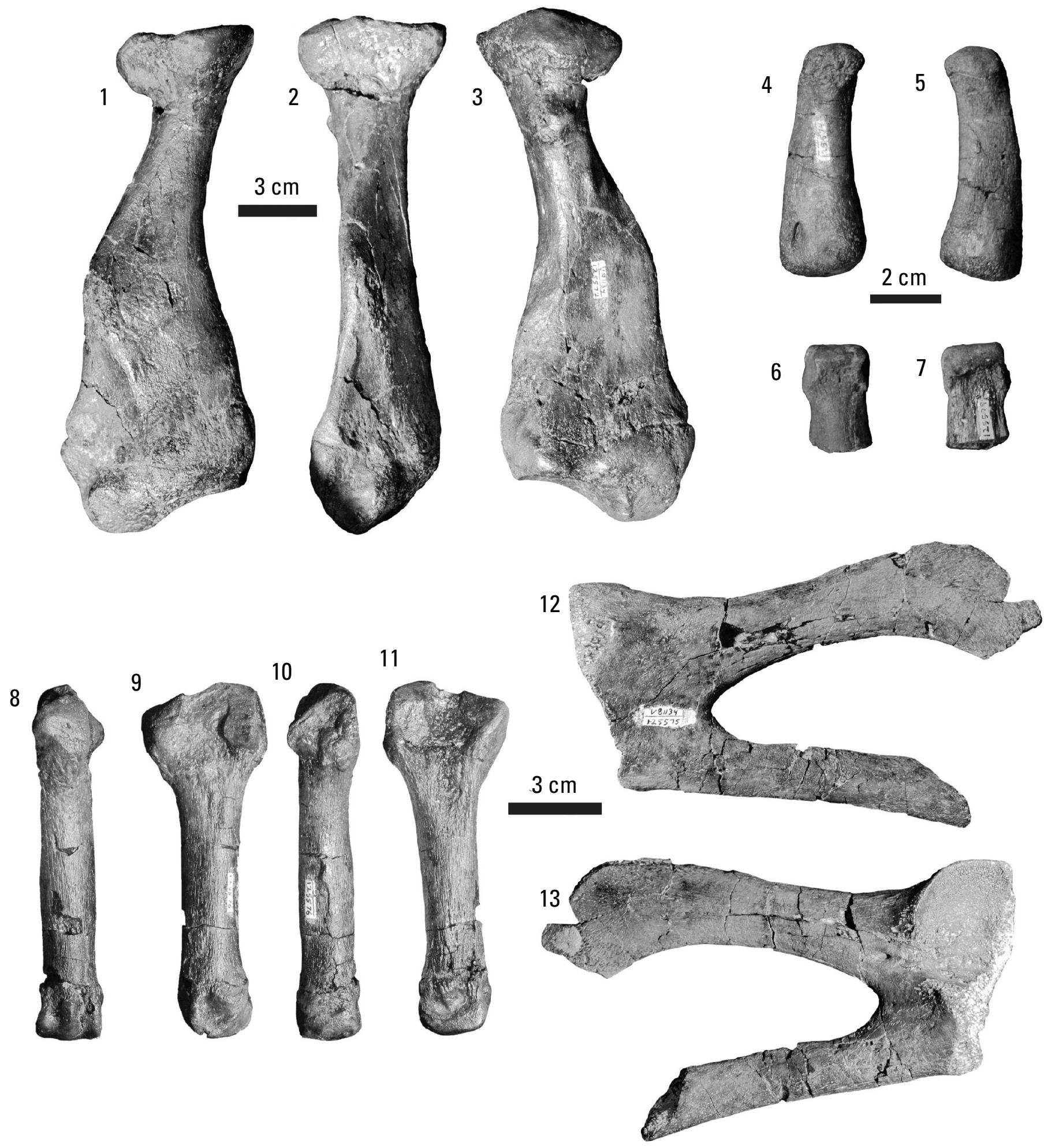


\section{Plate 6}

Walrus (Odobenidae) teeth from the basal Wilson Grove Formation exposed in Bloomfield Quarry, just north of the town of Bloomfield in Sonoma County, California. cm, centimeter. (Photographs by Robert Boessenecker, College of Charleston.)

Figures 1-3. Dusignathus santacruzensis Kellogg (1927). Partial right maxilla. UCMP 125571. 1, Lateral view; 2, medial view; 3 , ventral view.

4-5. Dusignathus santacruzensis Kellogg (1927). Canine tooth. UCMP 125571. 4, Labial view; 5, lingual view; 6 , mesial view. 

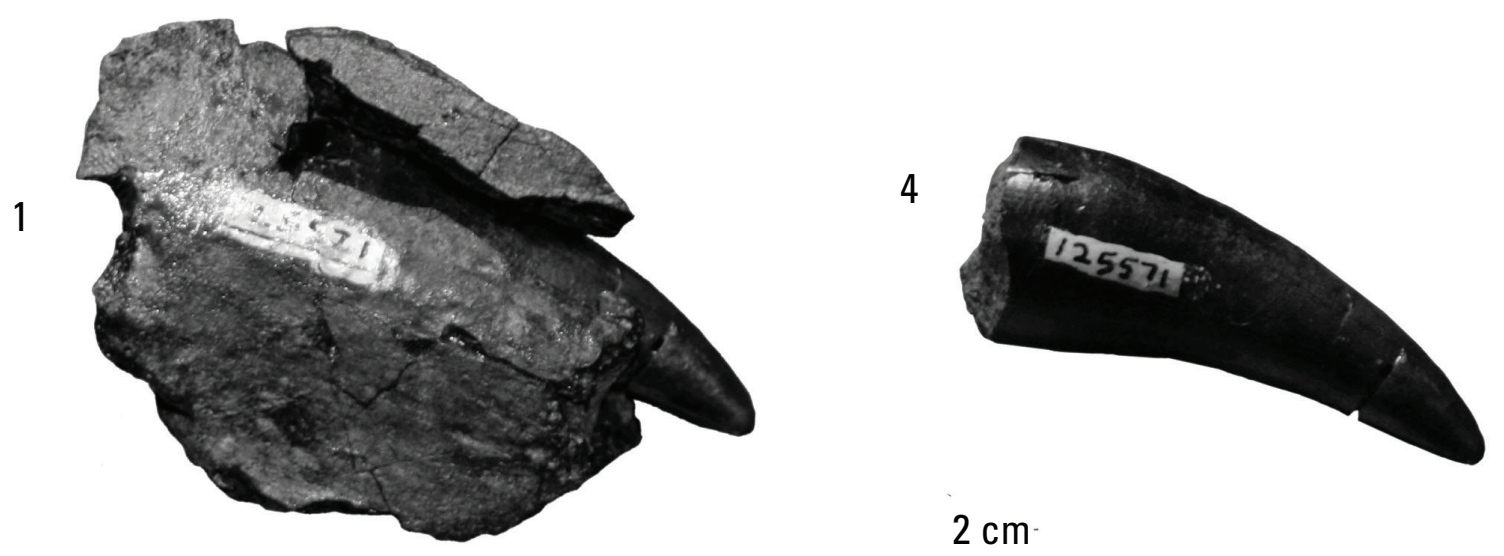

$1 \mathrm{~cm}$

$2 \mathrm{~cm}$
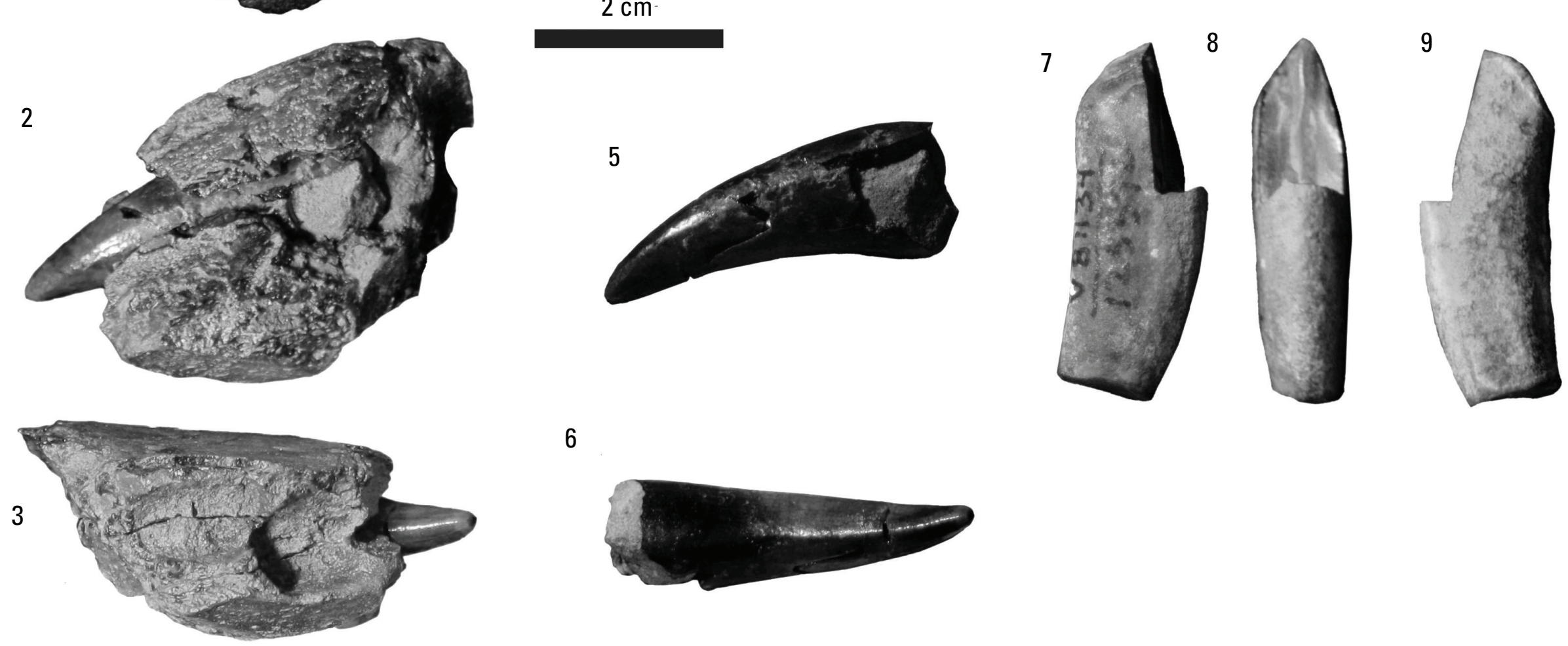

6

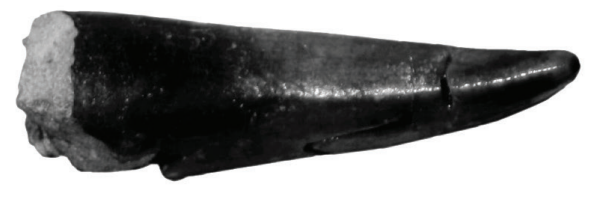

뭉 


\section{Plate 7}

Walrus (Odobenidae) mandible from the basal Wilson Grove Formation exposed in Bloomfield Quarry, just north of the town of Bloomfield in Sonoma County, California. cm, centimeter. (Photographs by Robert Boessenecker, College of Charleston.)

Figures

1-3. Dusignathus santacruzensis Kellogg (1927). Left mandible. UCMP 125567. 1, Lateral view; 2, dorsal view; 3 , medial view. 
Plate $7 \quad 61$

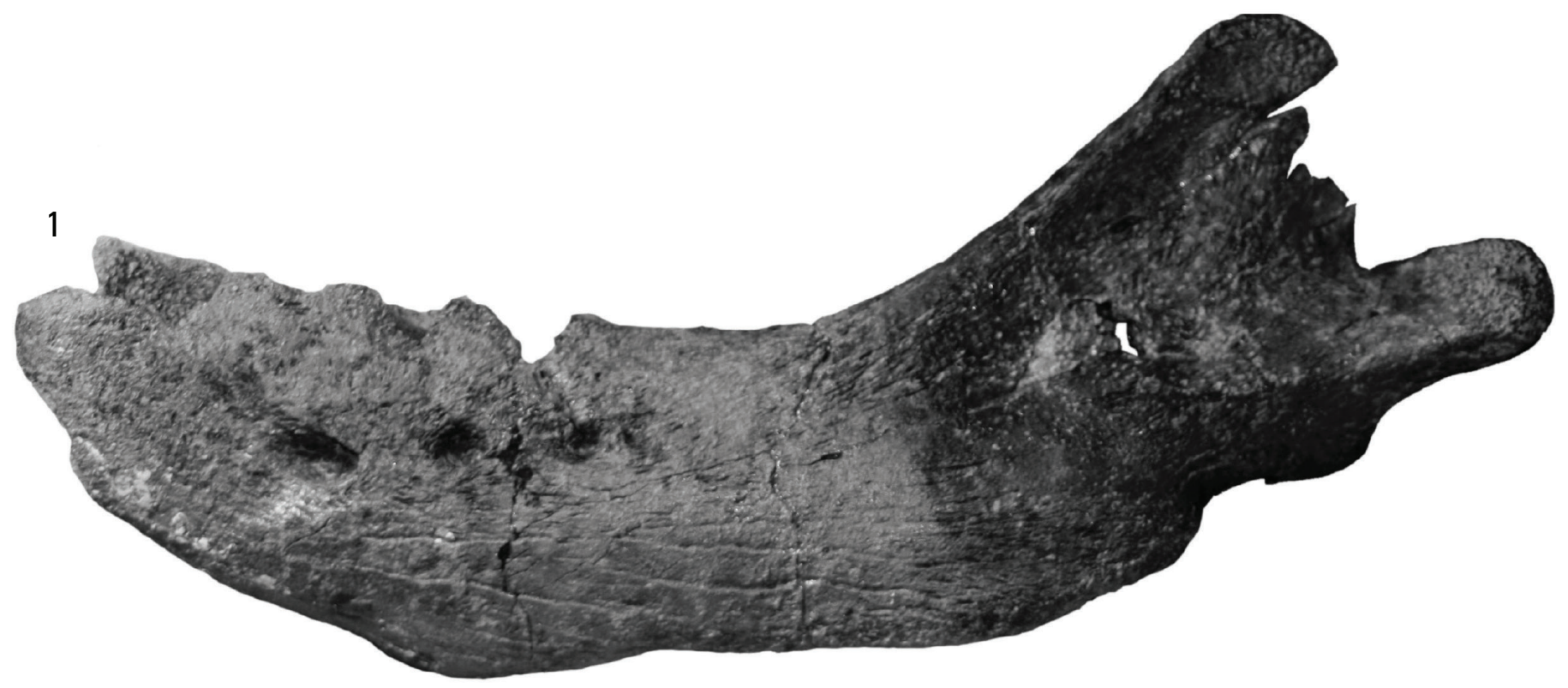

2
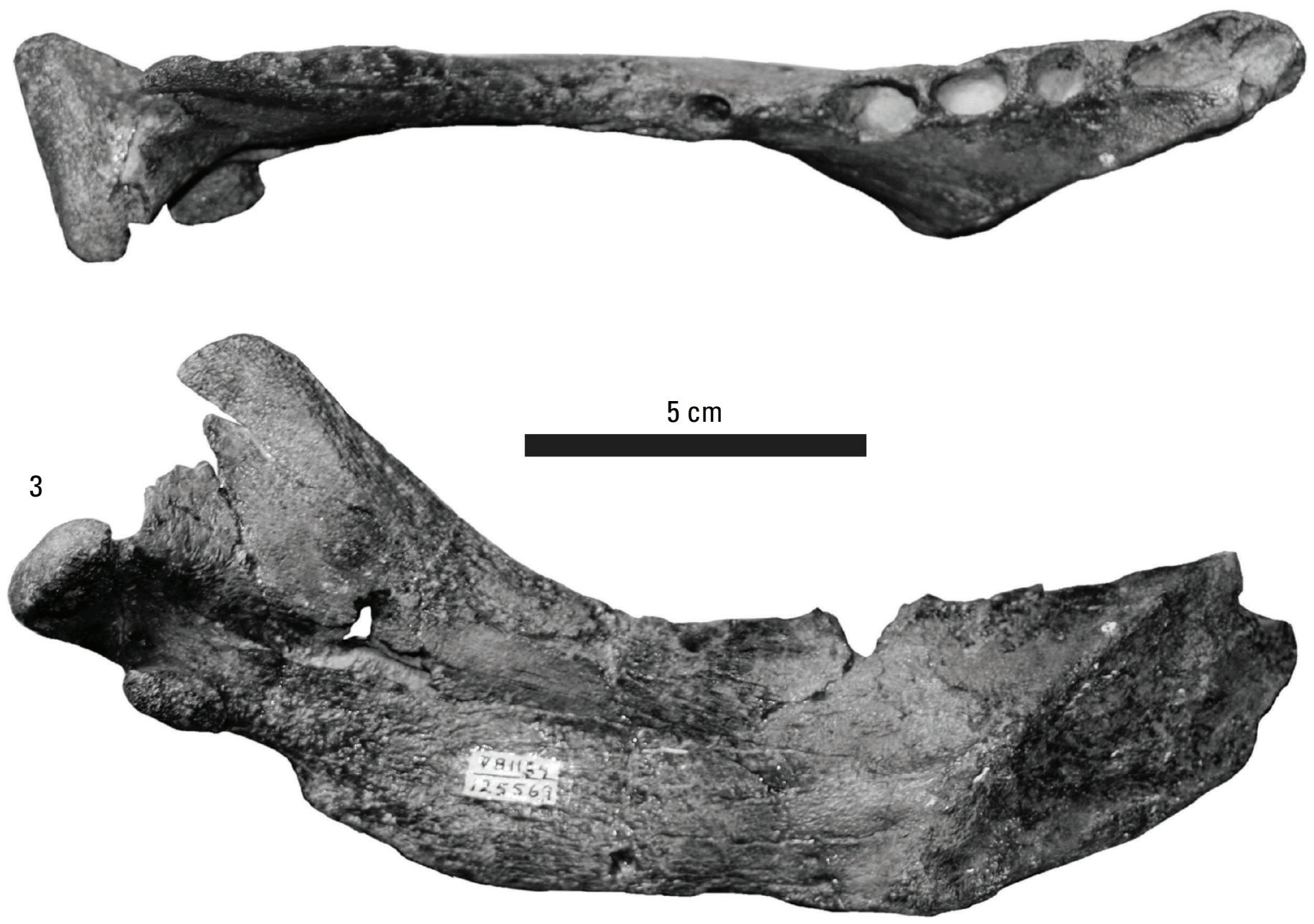


\section{Plate 8}

Walrus (Odobenidae) mandible from the basal Wilson Grove Formation exposed in Bloomfield Quarry, just north of the town of Bloomfield in Sonoma County, California. cm, centimeter. (Photographs by Robert Boessenecker, College of Charleston.)

Figures

1-4. Gomphotaria pugnax Barnes and Raschke (1991). Partial left mandible. UCMP 125570. 1, Lateral view; 2, medial view; 3, dorsal view; 4, lateral view, with other fragments. 


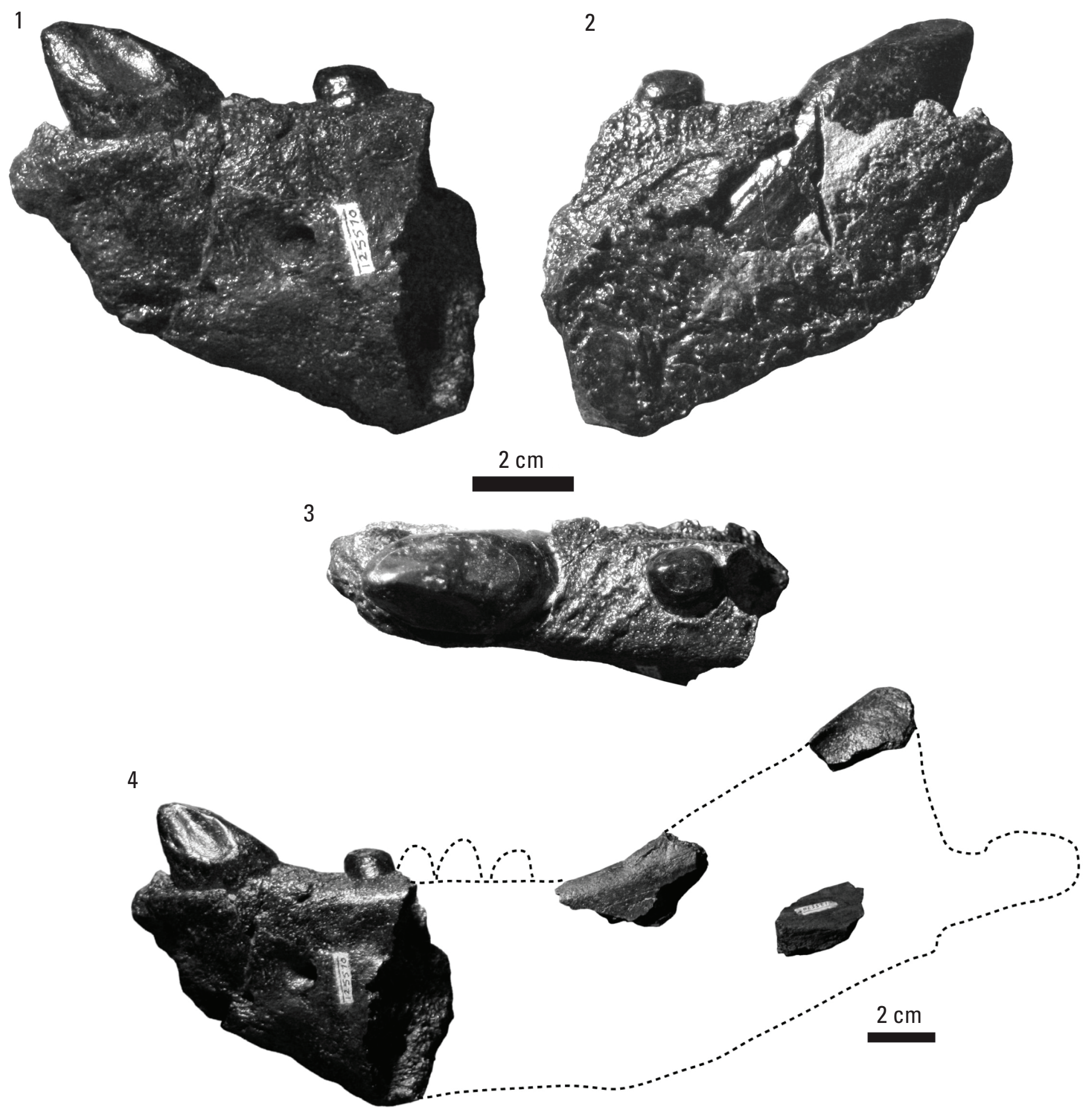




\section{Plate 9}

Walrus (Odobenidae) femur from the basal Wilson Grove Formation exposed in Bloomfield Quarry, just north of the town of Bloomfield in Sonoma County, California. cm, centimeter. (Photographs by Robert Boessenecker, College of Charleston.)

Figures

1-3. Cf. Pontolis sp. indeterminate. Right femur. UCMP 137438. 1, Anterior view; 2, lateral view; 3, posterior view. 

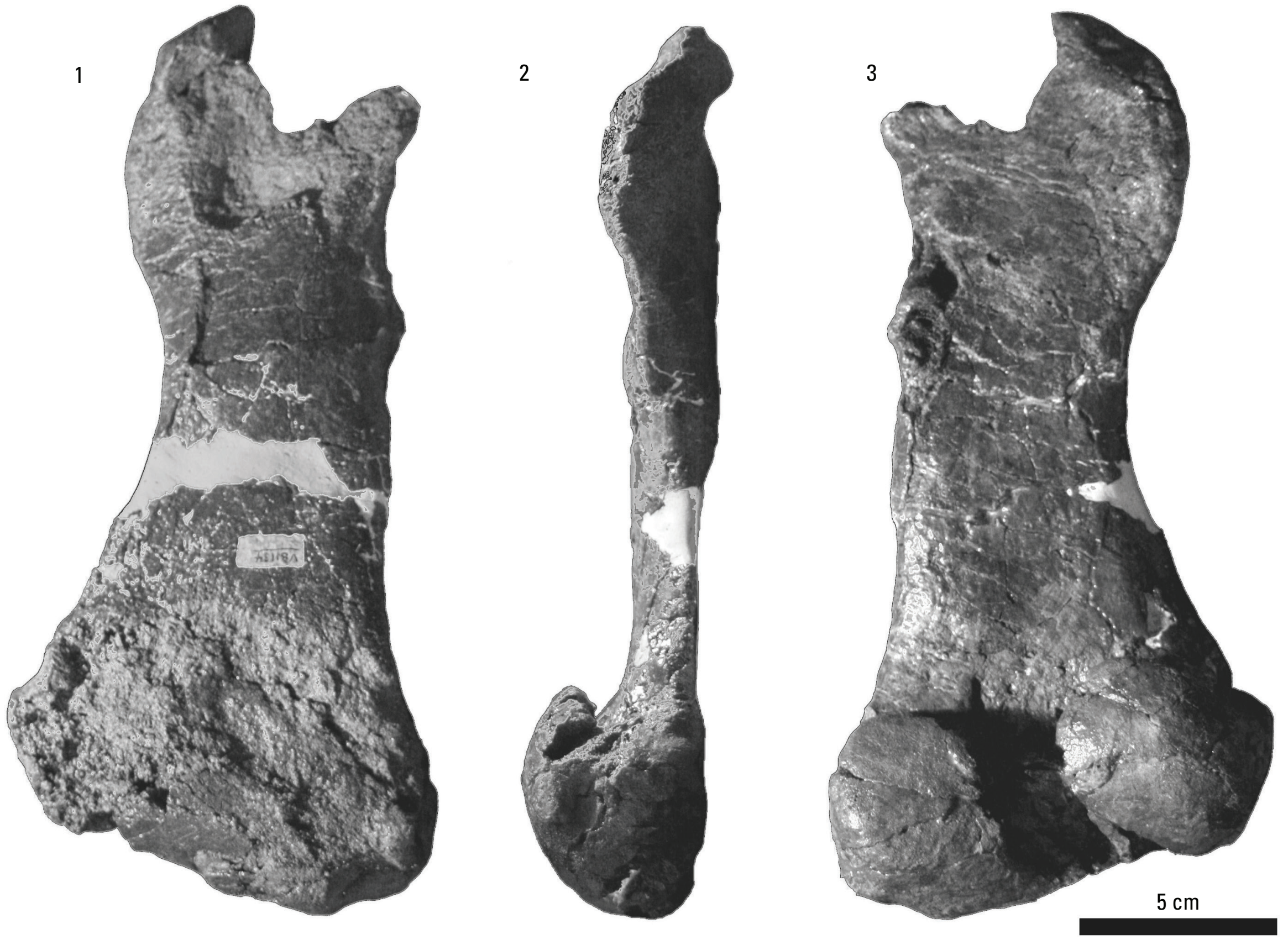

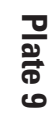




\section{Plate 10}

Dolphin (Odontoceti) teeth and bones from the basal Wilson Grove Formation exposed in Bloomfield Quarry, just north of the town of Bloomfield in Sonoma County, California. cm, centimeter. (Photographs by Robert Boessenecker, College of Charleston.)

Figures 1-3. Odontoceti indeterminate. Tooth. UCMP 125585. 1, Mesial or distal view; 2, lingual view; 3, occlusal view.

4. Odontoceti indeterminate. Lumbar vertebra. UCMP 125587. Anterior view.

5-6. Odontoceti indeterminate. Atlas vertebra. UCMP 125586. 5, Posterior view; 6, anterior view. 
1

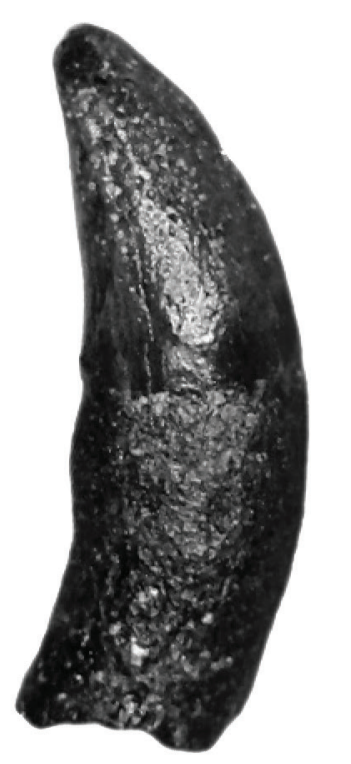

2

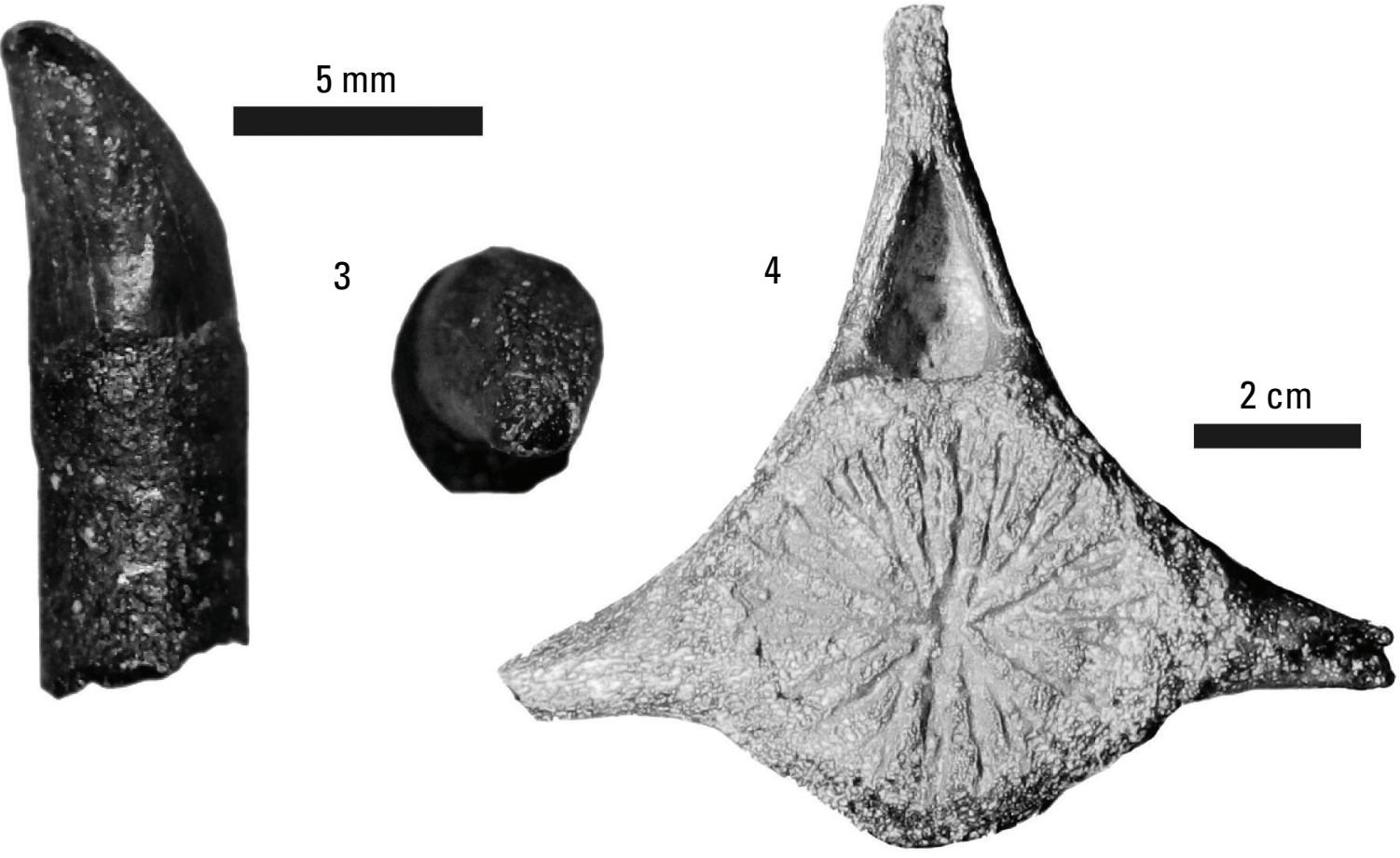

$2 \mathrm{~cm}$

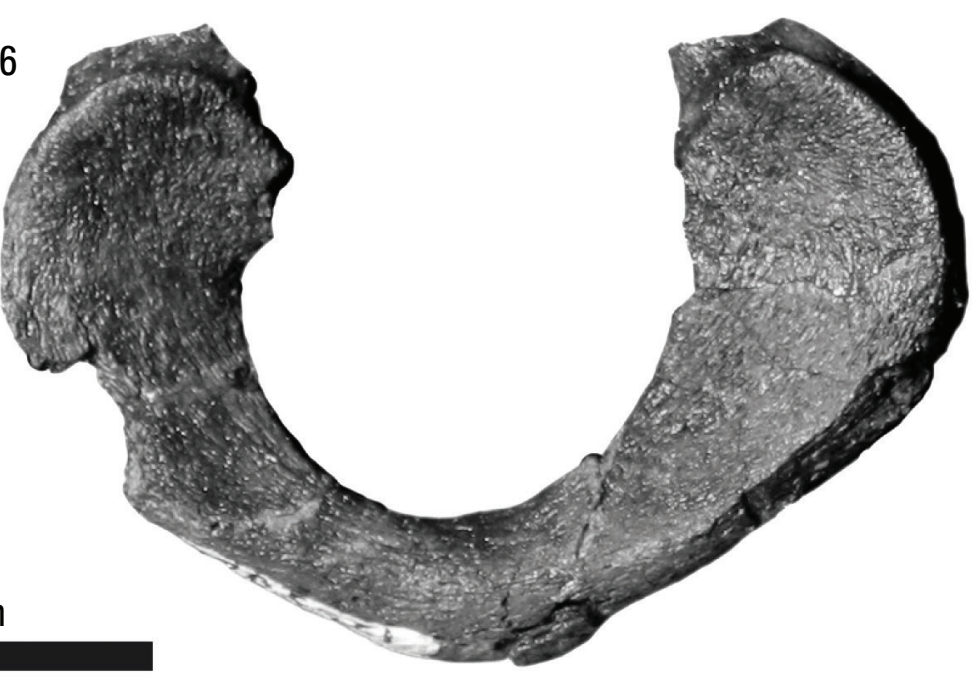

믈 


\section{Plate 11}

Baleen whale (Mysticeti) bones from the basal Wilson Grove Formation exposed in Bloomfield Quarry, just north of the town of Bloomfield in Sonoma County, California. cm, centimeter. (Photographs by Robert Boessenecker, College of Charleston.)

Figures

1-4. Balaenopteridae indeterminate. UCMP 125833. Partial left dentary. 1, Dorsal view; 2, lateral view; 3,4 , cross section.

5. Mysticeti indeterminate. Phalanx. UCMP 125596. Cervical vertebra. UCMP uncatalogued.

6. Mysticeti indeterminate. Cervical vertebra. UCMP uncatalogued.

7, 8. Herpetocetinae indeterminate. 1, 2, Frontal bone. UCMP uncatalogued.

9. Mysticeti indeterminate. Isolated vertebral epiphysis. UCMP 125597.

10. Mysticeti indeterminate. Isolated vertebral epiphysis. UCMP 125598. 


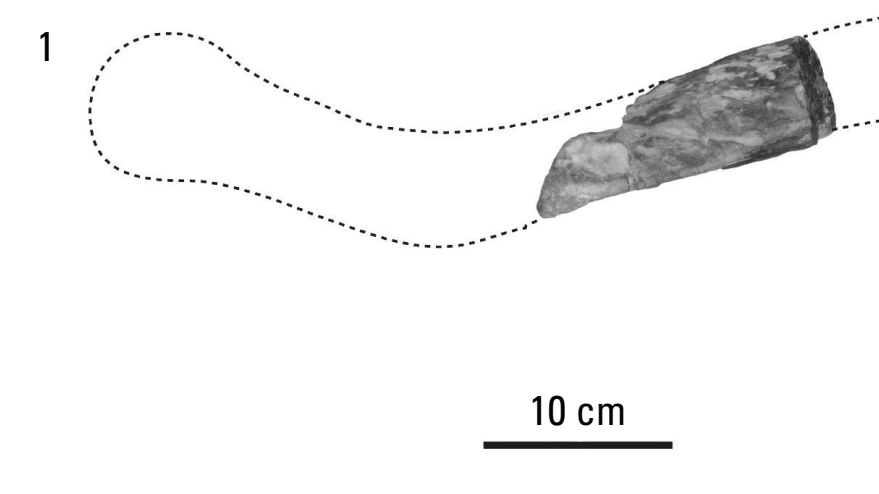

2
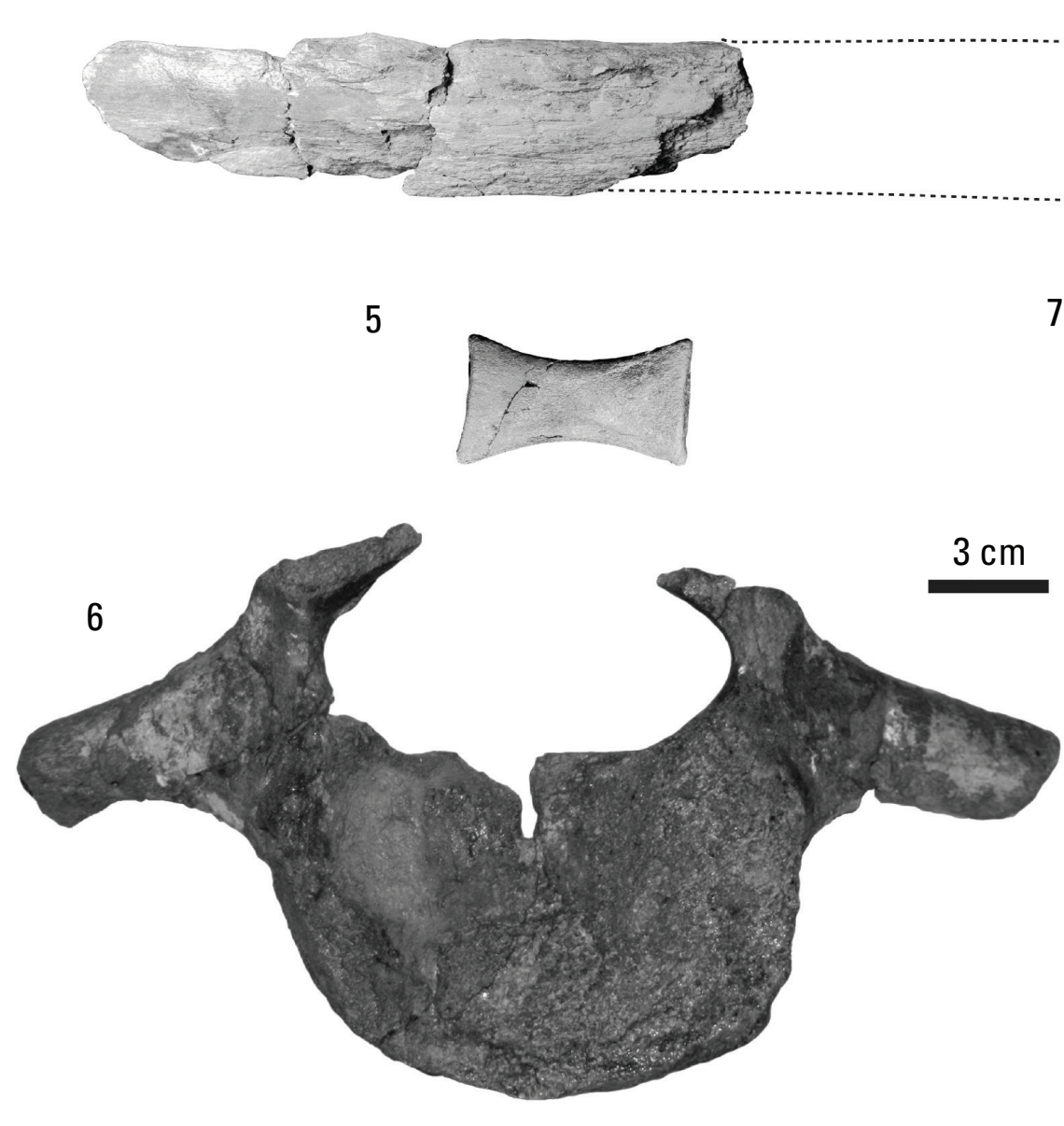

7

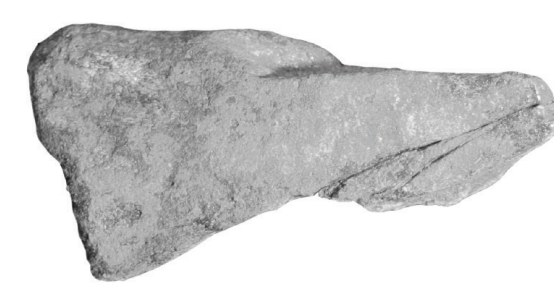

$3 \mathrm{~cm}$
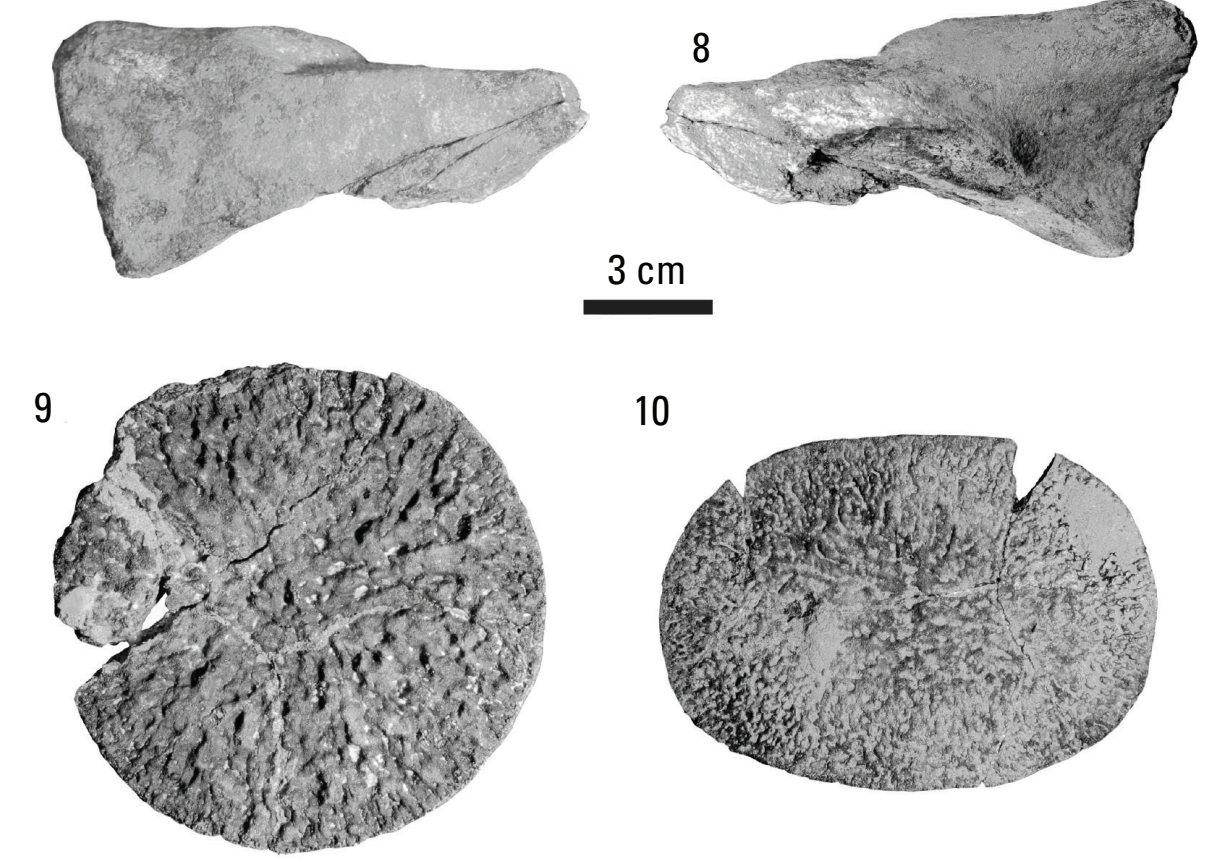

10

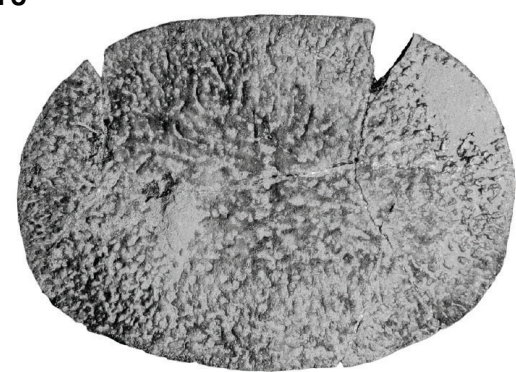

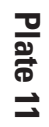




\section{Plate 12}

Sea cow (Hydrodamalinae) rib fragments from the basal Wilson Grove Formation exposed in Bloomfield Quarry, just north of the town of Bloomfield in Sonoma County, California. cm, centimeter. (Photographs by Robert Boessenecker, College of Charleston.)

Figures $\quad 1,4$. Hydrodamalinae indeterminate. Rib fragment. UCMP 125594. 1, Cross section; 4, external view.

5, 6, 2, 3. Hydrodamalinae indeterminate. Rib fragment. UCMP 125595. 5, 6, External views; 2, 3, crosssectional views. 

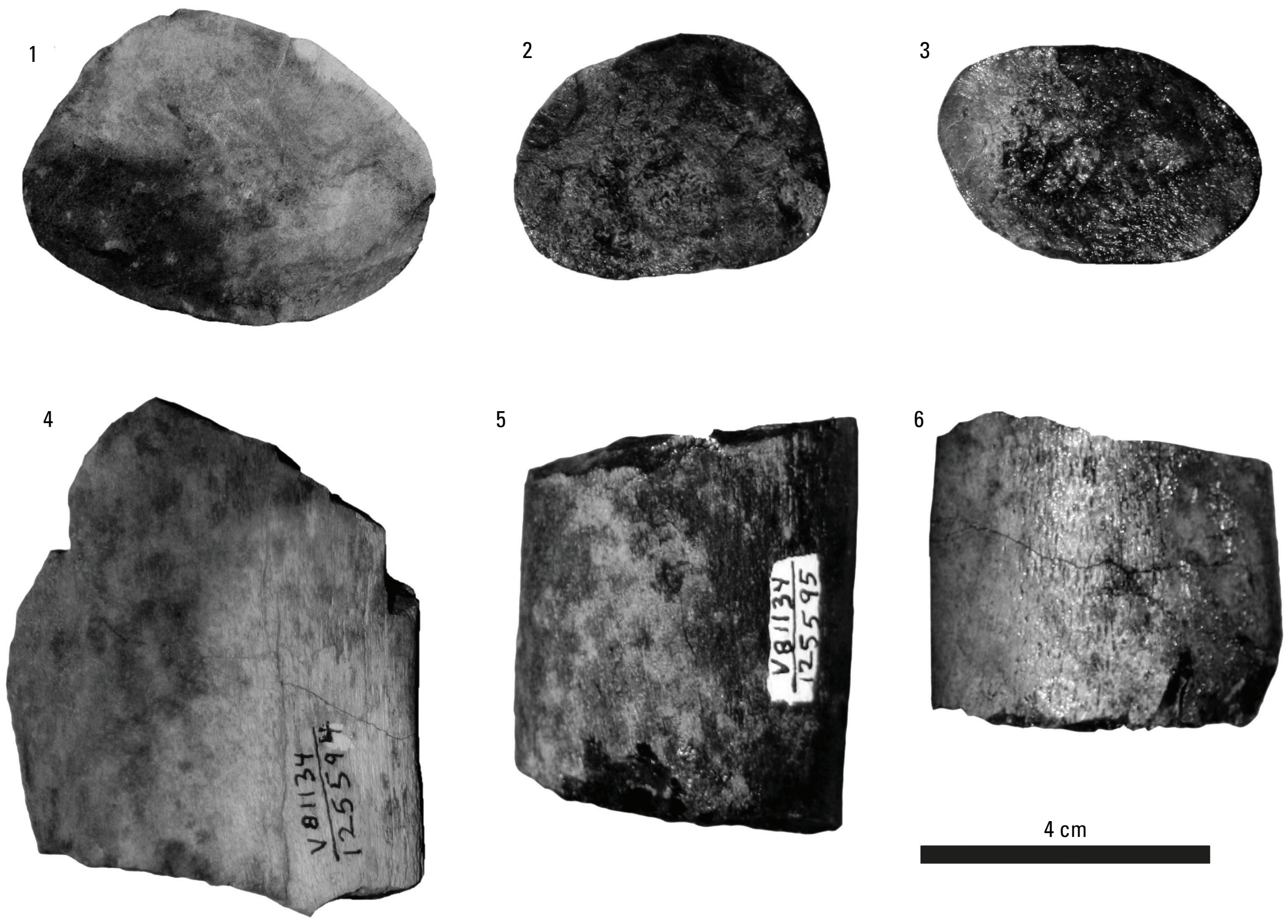

$4 \mathrm{~cm}$

$\frac{0}{\frac{0}{0}}$ 


\section{Plate 13}

Fragmented avian fossils from the basal Wilson Grove Formation exposed in Bloomfield Quarry, just north of the town of Bloomfield in Sonoma County, California. dc, deltopectoral crest; bs, musculus brachialis scar; md, medial epicondylar depression; sb, supratindinal bridge; cm, centimeter. (Photographs by N. Adam Smith, Campbell Geology Museum, Clemson University.)

Figures 1, 2. Aves indeterminate. Distal end of tibiotarsus. UCMP 128208. 1, anterior view; 2, medial view.

3, 4. Pan-Alcidae indeterminate. Ulnar shaft. UCMP 128209. 3, Anterior view; 4, ventral view.

5, 6. Pan-Alcidae indeterminate. Humeral shafts. UCMP 128210. 5, Dorsal view; 6 , ventral view. 
Plate $13 \quad 73$

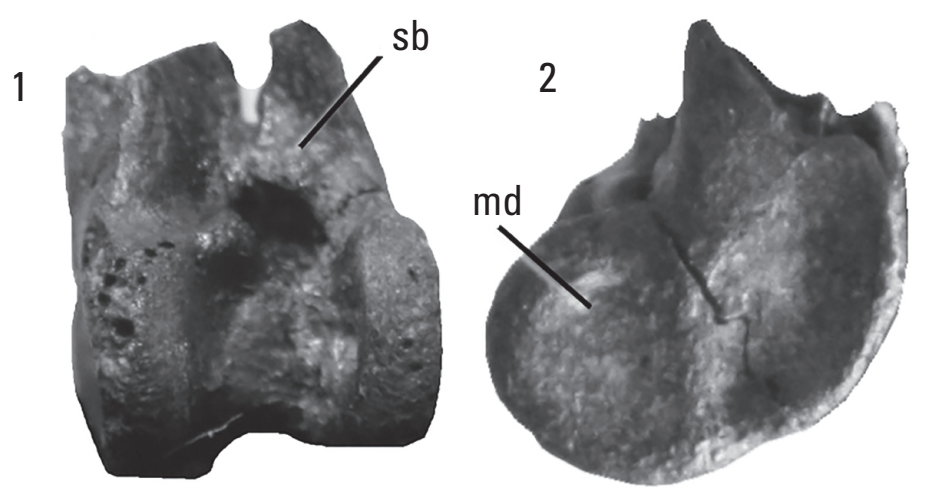

3
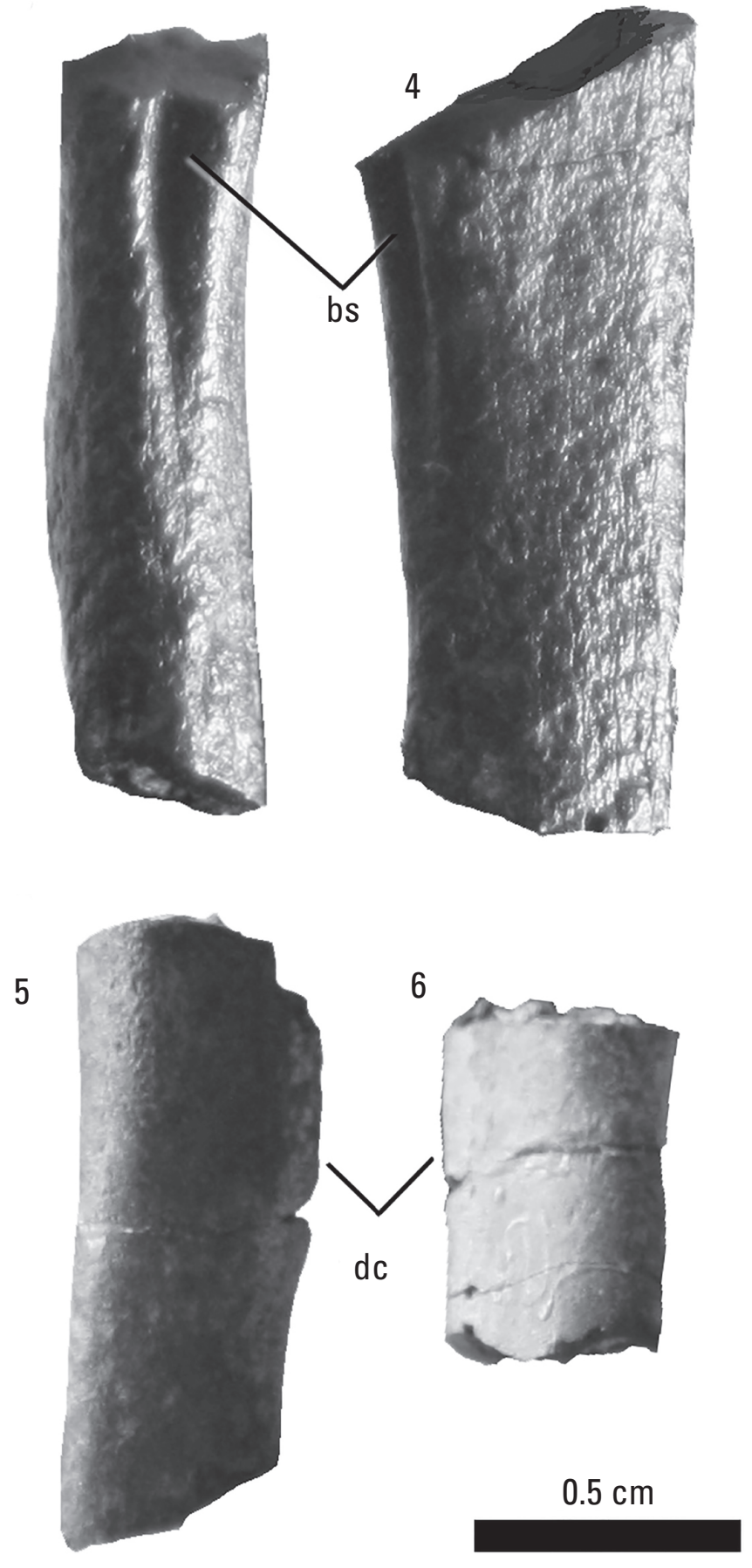


\section{Plate 14}

Flightless auk (Mancallinae) fossil from the basal Wilson Grove Formation exposed in Bloomfield Quarry, just north of the town of Bloomfield in Sonoma County, California. hf, humeral facet; ff, furcular facet; pp, procoracoid process; sa, sternal articulation; sf, scapular facet; ss, musculus supracoracoideus scar; cm, centimeter. (Photographs by N. Adam Smith, Campbell Geology Museum, Clemson University.)

Figures 1-3. Mancallinae indeterminate. Right coracoid. UCMP 128207. 1, Ventral view; 2, dorsal view; 3, lateral view. 
Plate $14 \quad 75$

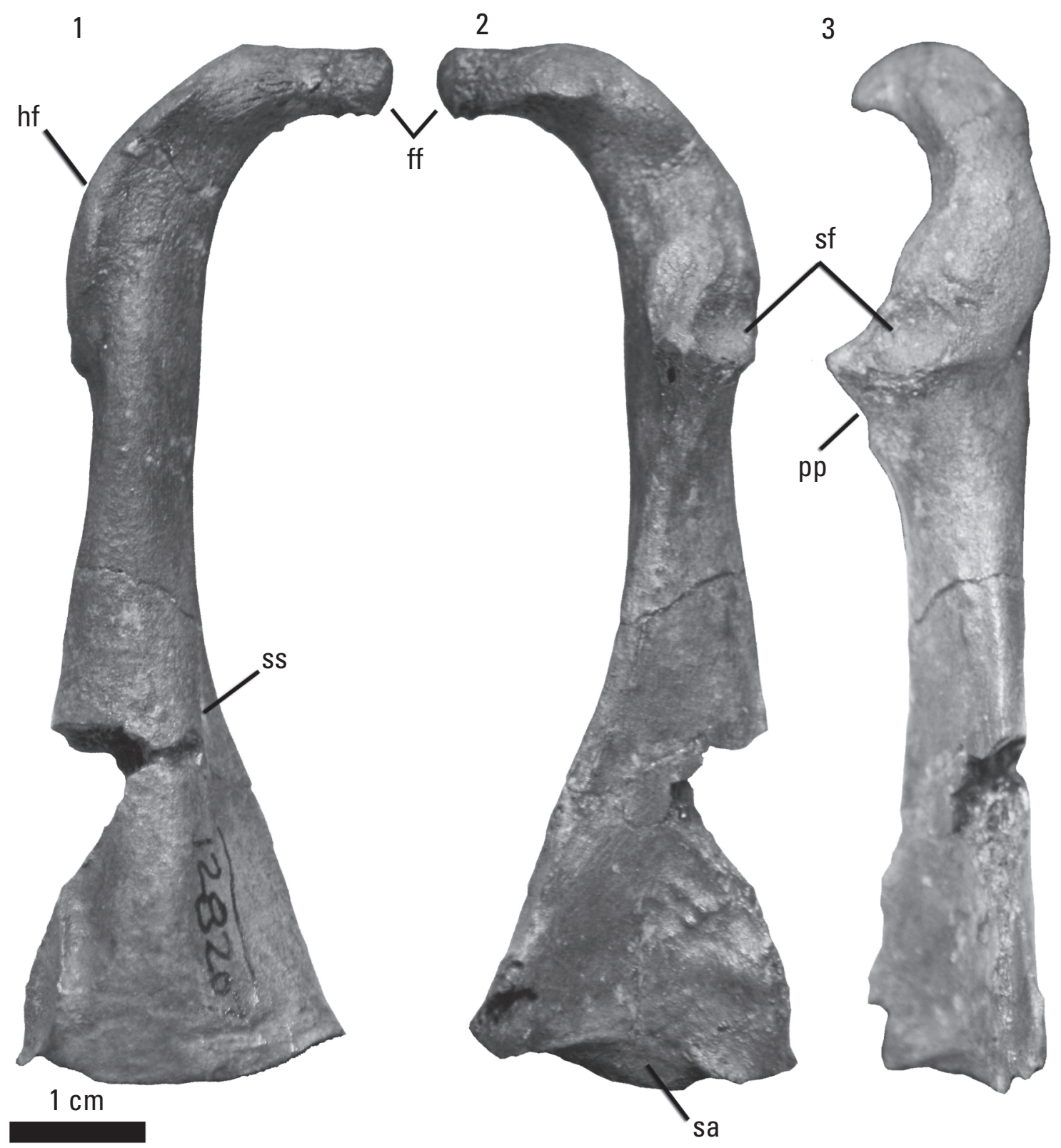




\section{Plate 15}

Auk (cf. Uria brodkorbi Howard, 1981) fossil from the basal Wilson Grove Formation exposed in Bloomfield Quarry, just north of the town of Bloomfield in Sonoma County, California. bc, bicipital crest; cg, capital groove; cs, coracobrachialis sulcus; dc, deltopectoral crest; hh, humeral head; pf1, primary pneumotricipital fossa; pf2, secondary pneumotricipital fossa; sc, musculus supracoracoideus scar; vt, ventral tubercle; cm, centimeter. (Photographs by N. Adam Smith, Campbell Geology Museum, Clemson University.)

Figures

1, 2. Cf. Uria brodkorbi Howard, 1981. Proximal end of right humerus. UCMP 128206. 1, Anterior view; 2, posterior view. 


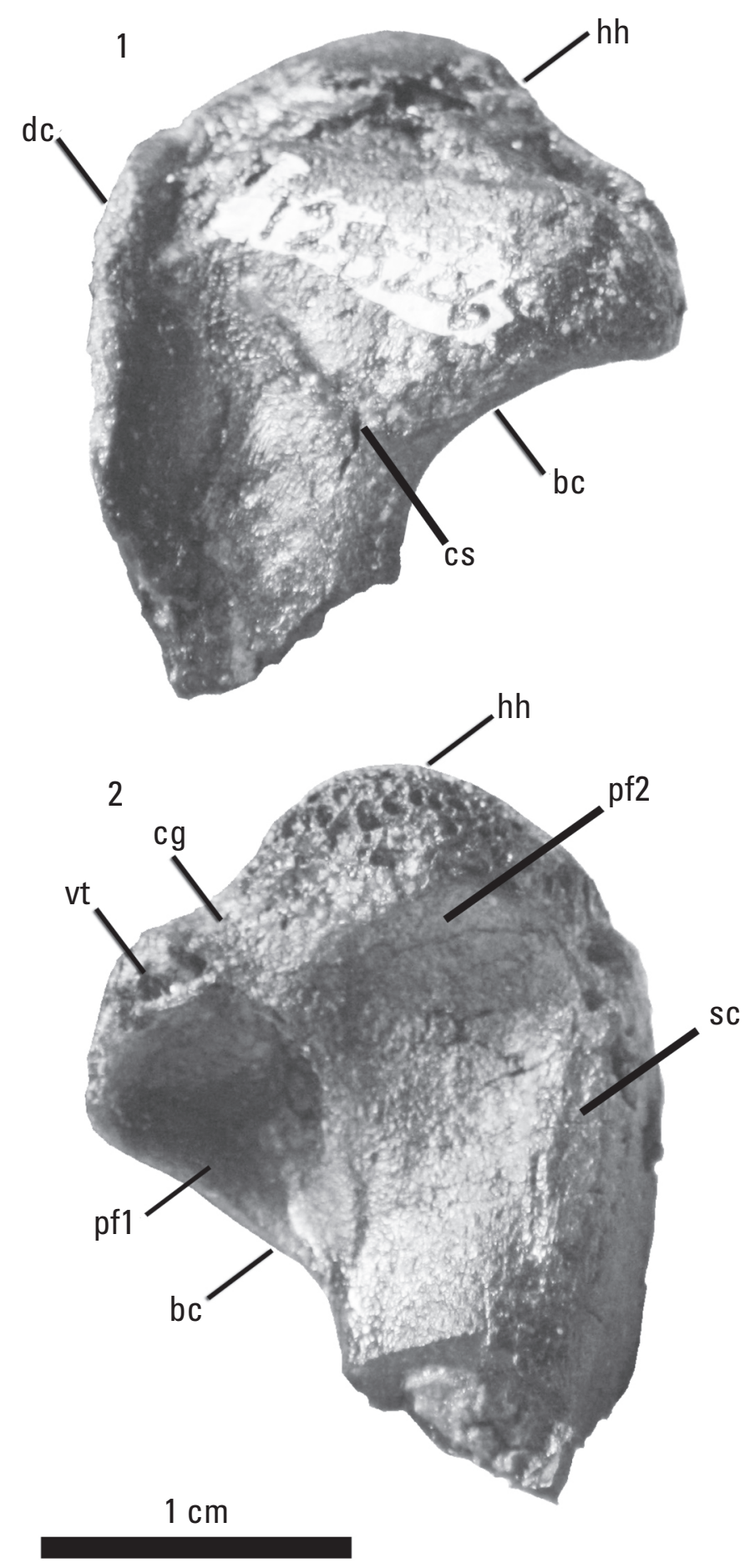



Menlo Park Publishing Service Center, California

Manuscript approved for publication March 25, 2019

Edited by James W. Hendley II

Layout and design by Kimber Petersen 
<smiles>ICI(I)I</smiles> 